Prepared in cooperation with the New Jersey Department of Environmental Protection

\title{
Methods Used to Reconstruct Historical Daily Streamflows in Northern New Jersey and Southeastern New York, Water Years 1922-2010
}

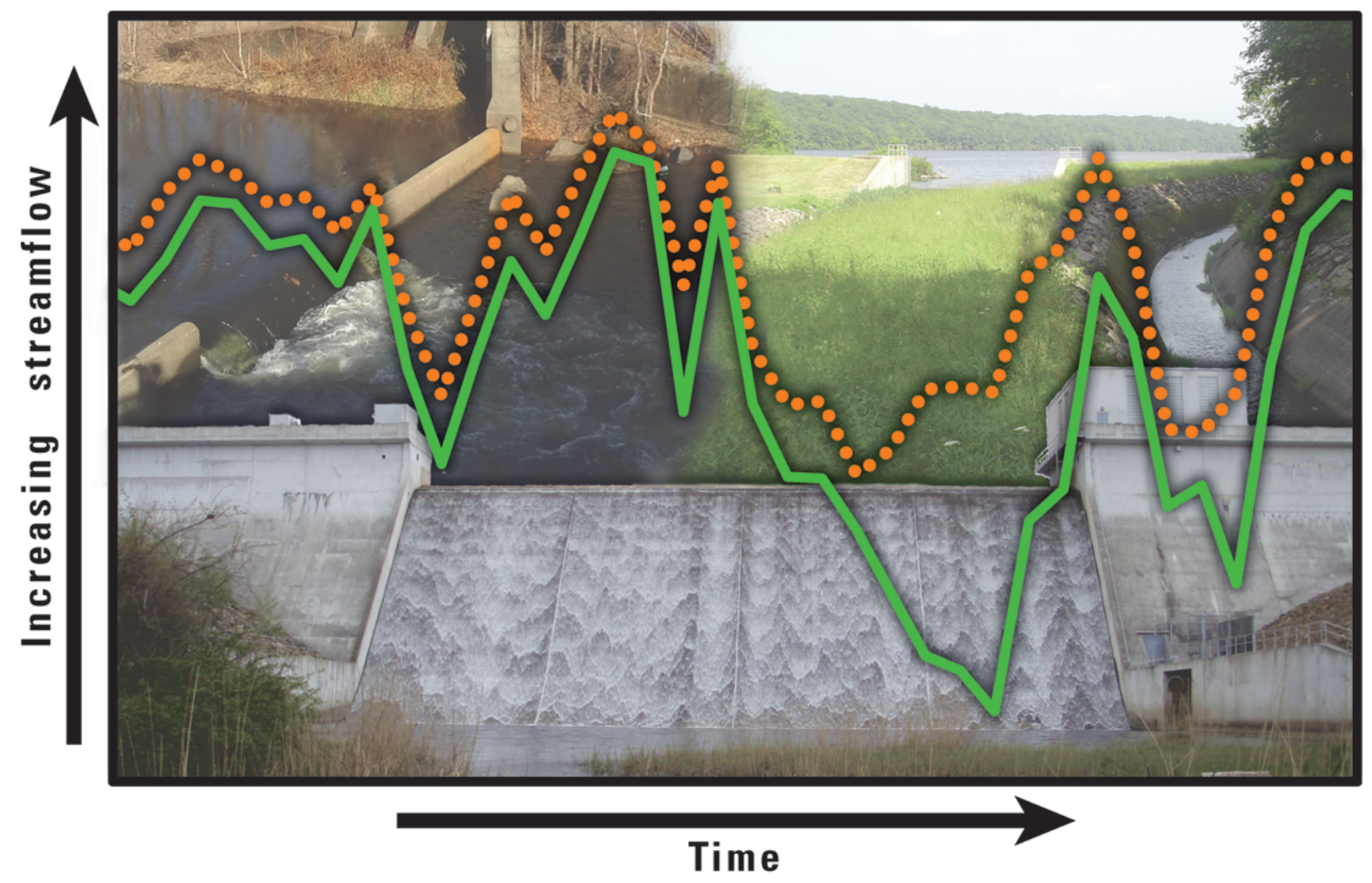

Scientific Investigations Report 2018-5068 
Cover. Reconstructed streamflow values (orange, dotted line) are calculated from observed streamflow (green line) and adjusted for effects of diversions and reservoir storage, providing what streamflow would have been without those components of water use. Photos of U.S. Geological Survey (USGS) streamgage: (clockwise from upper left) 01388500 Pompton River at Pompton Plains, NJ, by Bob Atkinson, USGS; 01382430 Mathews Brook diversion near Macopin, NJ, by Amy McHugh, USGS; and 01382381 Pequannock River at Charlotteburg, NJ, by Richard Edwards, USGS. 


\section{Methods Used to Reconstruct Historical Daily Streamflows in Northern New Jersey and Southeastern New York, Water Years 1922-2010}

By R. Edward Hickman and Amy R. McHugh

Prepared in cooperation with the

New Jersey Department of Environmental Protection

Scientific Investigations Report 2018-5068 


\title{
U.S. Department of the Interior \\ RYAN K. ZINKE, Secretary
}

\author{
U.S. Geological Survey \\ James F. Reilly II, Director
}

U.S. Geological Survey, Reston, Virginia: 2018

For more information on the USGS - the Federal source for science about the Earth, its natural and living resources, natural hazards, and the environment-visit https://www.usgs.gov or call 1-888-ASK-USGS.

For an overview of USGS information products, including maps, imagery, and publications,

visit https://store.usgs.gov.

Any use of trade, firm, or product names is for descriptive purposes only and does not imply endorsement by the U.S. Government.

Although this information product, for the most part, is in the public domain, it also may contain copyrighted materials as noted in the text. Permission to reproduce copyrighted items must be secured from the copyright owner.

Suggested citation:

Hickman, R.E., and McHugh, A.R., 2018, Methods used to reconstruct historical daily streamflows in northern New Jersey and southeastern New York, water years 1922-2010: U.S. Geological Survey Scientific Investigations Report 2018-5068, 75 p., https://doi.org/10.3133/sir20185068. 


\section{Contents}

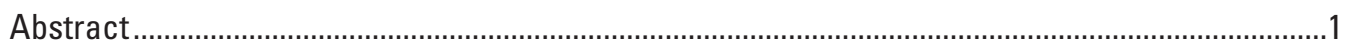

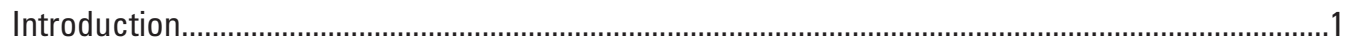

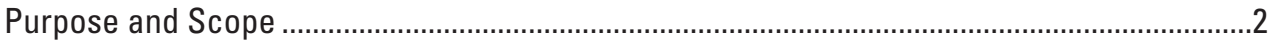

Description of Study Area ..............................................................................................

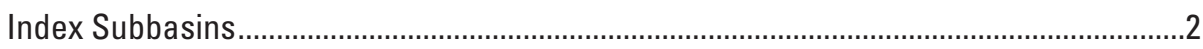

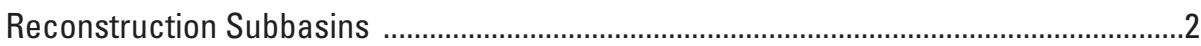

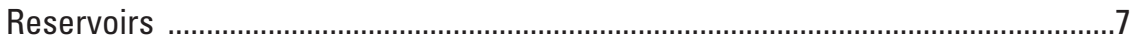

Surface-Water Diversions......................................................................................

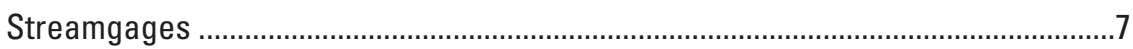

Partial-Record Stations ..........................................................................................

Flow-Reconstruction Sites ....................................................................................

Description of Selected Features in Each Reconstruction Subbasin ................................7

Hackensack River, Saddle River, Hirshfeld Brook, and Sparkill Creek......................7

Pequannock River and Double Kill............................................................................

Wanaque River and Long House Creek ...................................................................

Pompton River ..........................................................................................................

Rockaway River, Musconetcong River, and Whippany River .....................................

Main Stem Passaic River ..................................................................................

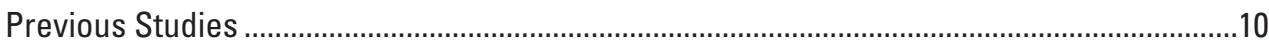

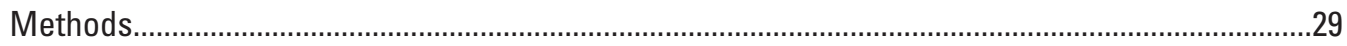

Assembling Information Needed to Determine Monthly Reconstructed Flows ....................29

Monthly Observed Streamflow at Streamgages .......................................................29

Daily and Monthly Observed Streamflows at Partial-Record Stations ..........................29

Rates of Monthly Transfer at Surface-Water Diversions...............................................29

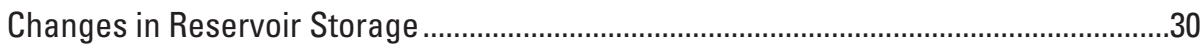

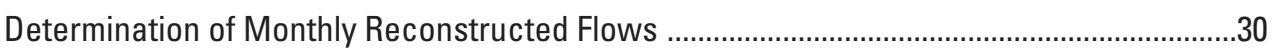

Calculation and Estimation of Monthly Reconstructed Flows at Sites with Monthly Streamflow....................................................................................30

Estimation of Monthly Reconstructed Flows from Corresponding Values at Other Sites ..................................................................................................

Determination of Daily Reconstructed Flows from Monthly Reconstructed Flows ...............32

Application of Methods to Flow-Reconstruction Sites in Each Subbasin ......................................40

Hackensack River, Saddle River, Hirshfeld Brook, and Sparkill Creek ..................................40

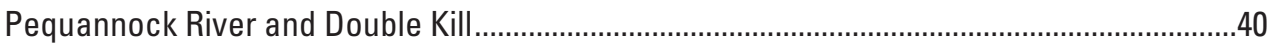

Wanaque River and Long House Creek ..............................................................................40

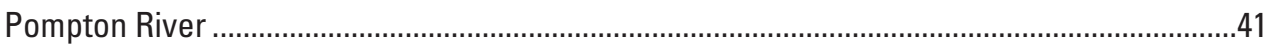

Rockaway River, Musconetcong River, and Whippany River ................................................41

Main Stem Passaic River .................................................................................................. 42 
Limitations and Assessment of Reconstructed Flows ................................................................62

Calculation of Monthly Reconstructed Flows from Observed Streamflow, Changes in Reservoir Storage, and Surface-Water Diversions..................................................62

Estimation of Monthly Reconstructed Flows and Sectional Monthly Reconstructed Flows from Relations with Monthly Observed Flows at Index Gages ...........................63

Determination of Daily Reconstructed Flows from Disaggregation of Monthly Reconstructed Flows ...................................................................................................63

Daily and Monthly Reconstructed Flows Determined from Discrete Streamflow Measurements at Partial-Record Stations .................................................................63

Assessment of Reconstructed Streamflows...........................................................................63

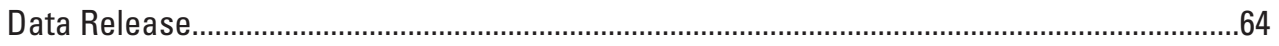

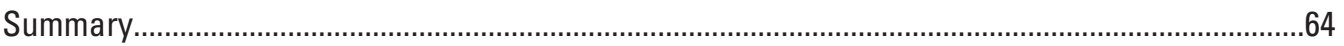

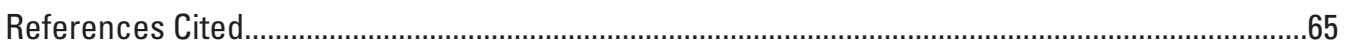

Appendix 1. Estimation of Monthly Observed Streamflows at Selected Streamgages ..................67

Appendix 2. Calculation of Monthly Observed Streamflows in Beaver Brook at the Outlet of Splitrock Reservoir from Furnished Data....................................................................69

Appendix 3. Estimation of Observed Daily Streamflow at Six Partial-Record Stations ...................71

Appendix 4. Estimation of Monthly Transfer Rates of the Three Pipe Diversions Used by the North Jersey District Water Supply Commission to Transfer Water

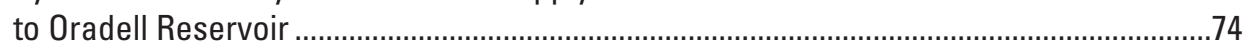

Appendix 5. Maintenance of Variance Extension Type 1 ……........................................................75 


\section{Figures}

1. Map showing groups of reconstruction subbasins and index subbasins in northern New Jersey and southeastern New York...

2. Map showing index subbasins and index gages in northern New Jersey. .4

3. Map showing reconstruction subbasins, outlets of each subbasin, and selected streamgages used to disaggregate monthly reconstructed streamflows in northern New Jersey and southeastern New York.

4. Map showing selected features of the subbasins of the Hackensack River, Saddle River, Hirshfeld Brook, and Sparkill Creek in northern New Jersey and southeastern New York.

5. Map showing selected features of the subbasins of the Pequannock River and Double Kill in northern New Jersey and southeastern New York

6. Map showing selected features of the subbasins of the Wanaque River and Long House Creek in northern New Jersey and southeastern New York.

7. Map showing selected features of the subbasin of the Pompton River in northern New Jersey and southeastern New York.

8. Map showing selected features of the subbasins of the Rockaway River, Musconetcong River, and Whippany River in northern New Jersey

9. Map showing selected features of the subbasin of the Main Stem Passaic River in northern New Jersey.

10. Schematic diagram of streamflow in the subbasins of the Hackensack River, Saddle River, Hirshfeld Brook, and Sparkill Creek, northern New Jersey and southeastern New York.

11. Schematic diagram of streamflow in the subbasins of the Pequannock River and Double Kill, northern New Jersey

12. Schematic diagram of streamflow in the subbasins of the Wanaque River and Long House Creek, northern New Jersey and southeastern New York.

13. Schematic diagram of streamflow in the Pompton River subbasin, northern New Jersey.

14. Schematic diagram of streamflow in the subbasins of the Rockaway, Musconetcong, and Whippany Rivers, northern New Jersey.

15. Schematic diagram of streamflow in the Main Stem Passaic River subbasin, northern New Jersey.

16. Graph showing monthly reconstructed streamflows in the Hackensack River at West Nyack, N.Y. (01376800/Recon04) as a function of monthly streamflows in Paulins Kill at Blairstown, N.J. (01443500), water years 1959-79

17. Graph showing sectional monthly reconstructed flows upstream from the Passaic River at Little Falls, N.J. (01389500/Recon53), as a function of monthly observed streamflow in the Paulins Kill at Blairstown, N.J. (01443500), water years 2006-10. 


\section{Tables}

1. Description of index subbasins with index streamgages in northern New Jersey ..........2

2. Description of reconstruction subbasins in northern New Jersey and southeastern New York

3. Description of selected reservoirs in the reconstruction subbasins in northern New Jersey and southeastern New York

4. Selected surface-water diversion sites in the reconstruction subbasins in northern New Jersey and southern New York.

5. Periods of records for observed streamflows at selected streamgages in the reconstruction subbasins in northern New Jersey and southeastern New York ...........23

6. Description of selected partial-record stations in the reconstruction subbasins in northern New Jersey and southeastern New York... .25

7. Description of flow-reconstruction sites in the reconstruction subbasins in northern New Jersey and southeastern New York.

8. Sources of monthly rates of transfer at selected surface-water pipe diversion sites in northern New Jersey and southeastern New York. .33

9. Periods of calculated reconstructed flows used to develop relations at selected flow-reconstruction sites, by subbasin, in northern New Jersey and southeastern New York and periods over which monthly reconstructed flows were estimated with these relations.

10. Disaggregation streamgages used to determine daily reconstructed flows from monthly reconstructed flows at flow-reconstruction sites in northern New Jersey and southeastern New York

11. Data types used to determine reconstructed flows at sites in the subbasins of Hackensack River, Saddle River, Hirshfeld Brook, and Sparkill Creek, northern New Jersey and southeastern New York, during 1922-2010

12. Streamflow adjustment terms used to calculate monthly reconstructed flows at selected flow-reconstruction sites in the subbasins of Sparkill Creek, Hackensack River, and Saddle River, northern New Jersey and southeastern New York, during water years 1922-2010

13. Data types used to determine reconstructed flows at sites in the subbasins of Pequannock River and Double Kill, northern New Jersey, during water years 1922-2010

14. Streamflow adjustment terms used to calculate monthly reconstructed flows at selected flow-reconstruction site in the subbasin of the Pequannock River, northern New Jersey, during water years 1922-2010.

15. Data types used to determine reconstructed flows at sites in the subbasins of Wanaque River and Long House Creek, northern New Jersey, during water years 1922-2010.

16. Streamflow adjustment terms used to calculate monthly reconstructed flows at flow-reconstruction sites in the subbasin of the Wanaque River, northern New Jersey, during water years 1922-2010

17. Data types used to determine reconstructed flows at reconstruction sites in the Pompton River subbasin in northern New Jersey, during water years 1922-2010.

18. Streamflow adjustment terms used to calculate monthly reconstructed flows at selected flow-reconstruction sites in the subbasin of the Pompton River, northern New Jersey, during water years 1922-2010. 
19. Streamflow adjustment terms and upstream streamgages used to calculate sectional monthly reconstructed flows at selected flow-reconstruction sites in the subbasins of the Pompton River and main stem Passaic River, northern New Jersey, during water years 1922-2010

20. Data types used to reconstruct flows at sites in the subbasins of Rockaway River, Musconetcong River, and Whippany River, northern New Jersey during water years 1922-2010

21. Streamflow adjustment terms used to calculate monthly reconstructed flows at selected flow-reconstruction sites in the subbasins of the Musconetcong, Rockaway, and Whippany Rivers, northern New Jersey, during water years 1922-2010

22. Data types used to estimate reconstructed flows at selected sites in the Main Stem Passaic River subbasin, northern New Jersey, water years 1922-2010. 60

23. Streamflow adjustment terms used to calculate monthly reconstructed flows at selected flow-reconstruction sites in the subbasin of the Main Stem Passaic River, northern New Jersey, during water years 1922-2010.. 


\section{Conversion Factors}

U.S. customary units to International System of Units

\begin{tabular}{lcl}
\hline \multicolumn{1}{c}{ Multiply } & By & \multicolumn{1}{c}{ To obtain } \\
\hline square mile $\left(\mathrm{mi}^{2}\right)$ & Area & hectare $($ ha) \\
square mile $\left(\mathrm{mi}^{2}\right)$ & 259.0 & square kilometer $\left(\mathrm{km}^{2}\right)$ \\
\hline & 2.590 & \\
\hline million gallons $(\mathrm{Mgal})$ & Volume & cubic meter $\left(\mathrm{m}^{3}\right)$ \\
\hline & 3,785 & \\
\hline cubic foot per second $(\mathrm{ft} / \mathrm{s})$ & Flow rate & cubic meter per second $\left(\mathrm{m}^{3} / \mathrm{s}\right)$ \\
million gallons per day $(\mathrm{Mgal} / \mathrm{d})$ & 0.02832 & cubic meter per second $\left(\mathrm{m}^{3} / \mathrm{s}\right)$ \\
\hline
\end{tabular}

\section{Datum}

Horizontal coordinate information is referenced to the North American Datum of 1927 (NAD 27) and the North American Datum of 1983 (NAD 83).

\section{Abbreviations}

MOVE1 Maintenance of Variance Extension type 1

NJDEP New Jersey Department of Environmental Protection

NJGWS New Jersey Geological and Water Survey

USGS U.S. Geological Survey 


\title{
Methods Used to Reconstruct Historical Daily Streamflows in Northern New Jersey and Southeastern New York, Water Years 1922-2010
}

\author{
By R. Edward Hickman and Amy R. McHugh
}

\section{Abstract}

A study was conducted by the U.S. Geological Survey, in cooperation with the New Jersey Department of Environmental Protection, to reconstruct streamflows for use in the RiverWare model. Methods and data used to estimate daily reconstructed streamflows at 53 sites in selected subbasins in northern New Jersey and southeastern New York are presented in the report. These subbasins contain one or more surfacewater diversions that are operated or have been operated in the past by water purveyors or the New Jersey Department of Environmental Protection. Reconstructed streamflows are estimates of those streamflows that would have occurred without the effects of changes in reservoir storage or surface-water diversions by water purveyors.

Reconstructed flows at 47 sites were determined from monthly observed streamflows, changes in reservoir storage, and surface-water diversions. Monthly reconstructed streamflows were calculated directly for those months with sufficient data. Missing monthly reconstructed flows were estimated from relations between selected calculated values of monthly reconstructed flows and monthly observed flows at selected index gages. Daily reconstructed flows were determined from the disaggregation of monthly reconstructed flows on the basis of daily observed flows at selected streamgages. At six sites, reconstructed flows were determined from relations between discrete measurements of observed streamflows and daily observed streamflows at selected index gages.

\section{Introduction}

Surface-water diversions from rivers and reservoirs in the basins of the Passaic and Hackensack Rivers in northern New Jersey and southeastern New York are important sources of water supply within and outside these basins (Storck and Nawyn, 2001). The diversions, operated by water purveyors, remove water to be treated and distributed for use or transfer water from one river basin to another. Some purveyors divert water from a stream or reservoir and transfer it to another purveyor.

The New Jersey Department of Environmental Protection (NJDEP) is responsible for regulating water purveyors in the State and for setting a safe yield for each water-supply reservoir system. "Safe yield" is defined as "that maintainable yield of water from a surface or groundwater source or sources which is available continuously during projected future conditions, including a repetition of the most severe drought of record, without creating undesirable effects, as determined by the Department" (New Jersey Department of Environmental Protection, 2011). "Department" is the New Jersey Department of Environmental Protection.

To aid in determining the safe yields of the surface-watersupply reservoir system, the NJDEP created a RiverWare computer model that simulates streamflow, reservoir storage, and surface-water diversions. The RiverWare model (Center for Advanced Decision Support for Water and Environmental Systems, n.d.) is a physically based, water-accounting model used to simulate water movement down a river while including effects of reservoir storage, diversions, and tributary streamflow. The RiverWare model was used by the NJDEP to simulate daily streamflow, reservoir storage, and surface-water diversions throughout selected subbasins of the Passaic and Hackensack Rivers and some adjacent streams during water years $^{1}$ 1922-2010.

Daily streamflow measurements during water years 1922-2010 at points (referred to as "flow-reconstruction sites") in subbasins of the Passaic and Hackensack Rivers and some adjacent streams are a required input to the RiverWare model. These streamflows, referred to as "reconstructed streamflows," are estimates of the streamflow that would have occurred if there were no reservoir storage and no surfacewater withdrawals by any of the purveyors included in the study. The USGS, in cooperation with the NJDEP, conducted a study to provide these required data for the RiverWare model.

\footnotetext{
${ }^{1}$ A water year is the 12-month period beginning October 1 and ending September 30; it is designated by the calendar year in which it ends.
} 


\section{Purpose and Scope}

The purpose of this report is to describe the data and methods used to estimate daily reconstructed streamflow at 53 sites (flow-reconstruction sites) in subbasins of the Passaic and Hackensack Rivers and some adjacent streams in northern New Jersey and southeastern New York during water years 1922-2010. The reconstructed streamflows are not intended to fully represent natural conditions because surficial aquifer withdrawals and effluent return flows were not included.

Selected features in each reconstruction subbasin and the application of the methods are described. In addition, the resulting reconstructed streamflows are discussed. A companion data release includes selected data used for calculations so that comparisons of reconstructed flows can be made between sites.

\section{Description of Study Area}

The study area consists of two groups of subbasins in northern New Jersey and southeastern New York State (fig. 1). One group, referred to as "reconstruction subbasins," includes those subbasins for which reconstructed flows are determined and encompasses an area of 986 square miles $\left(\mathrm{mi}^{2}\right)$. The second group of subbasins, referred to as "index subbasins," includes the subbasins that drain to selected streamgages (hereafter "index gages"). The records of streamflow from the index gages were used to estimate reconstructed flows in the reconstruction subbasins. The group of index subbasins encompasses an area of $232 \mathrm{mi}^{2}$.

\section{Index Subbasins}

Two index subbasins were used in the study (table 1, fig. 2). The Paulins Kill subbasin consists of the $126-\mathrm{mi}^{2}$ area draining to the index gage on the Paulins Kill at Blairstown, N.J. (station number 01443500). The Pequest River subbasin consists of the 106- $\mathrm{mi}^{2}$ area draining to the index gage on the Pequest River at Pequest, N.J. (01445500).
These index gages were so designated because of their location within the glacial extent and long record of streamflow (table 1, fig. 2), and because the variation over time of the streamflow at each gage appears to be due primarily to weather and not to changes in basin characteristics. The period of record for the streamgage on the Pequest River (01445500) is complete for water years 1922-2010 and that for the streamgage on the Paulins Kill (01443500) is complete for water years 1922-2010, except for 1977. Esralew and Baker (2008) examined records of streamflow at these gages for changes over water years 1922-2005 owing to changes in basin characteristics. They could identify no changes in the streamflow in the Paulins Kill but did identify a change in peak streamflows in the Pequest River about 1960 as a result of channelization. Only an identified change in daily streamflow at the index gage would present a problem in determining reconstructed streamflows in the context of this report.

\section{Reconstruction Subbasins}

The reconstruction subbasin group consists of 13 subbasins (table 2, fig. 3); each stream in the subbasins is tributary to, or part of, one of following major rivers: Passaic River, Hackensack River, Hudson River, or Delaware River. Each of the reconstruction subbasins contains (or has contained) one or more surface-water diversions operated by either selected water purveyors or the NJDEP.

The 13 reconstruction subbasins range in size from 4.62 to $259 \mathrm{mi}^{2}$ (table 2, fig. 3). Each subbasin was designated largely on the basis of the hydrologic information (observed streamflow, rates of transfer at surface-water diversions, and reservoir storage) for the outflow point (table 2). The hydrologic information for the outlet of each reconstruction subbasin varied by subbasin (table 2). For most outlets, there was a record of daily streamflows. For two outlets (Double Kill and Longhouse Creek), the records contained only discrete streamflow measurements. For three outlets (Hirshfeld Brook, Wanaque River, and Rockaway River), the records contained surface-water diversions. For this report, all surface-water

Table 1. Description of index subbasins with index streamgages in northern New Jersey.

[Latitude and longitude in degrees, minutes, seconds; datum for latitude and longitude is North American Datum of 1983. USGS, U.S. Geological Survey; N.J., New Jersey]

\begin{tabular}{|c|c|c|c|c|c|}
\hline \multirow[b]{2}{*}{$\begin{array}{l}\text { Index sub- } \\
\text { basin }\end{array}$} & \multicolumn{5}{|c|}{ Index streamgage } \\
\hline & $\begin{array}{l}\text { USGS station name } \\
\text { (station number) }\end{array}$ & Latitude & Longitude & $\begin{array}{l}\text { Drainage area } \\
\text { (square miles) }\end{array}$ & $\begin{array}{l}\text { Period of published streamflow data from USGS } \\
\text { records, during water years 1922-2014 (record is } \\
\text { complete unless otherwise indicated) }\end{array}$ \\
\hline Paulins Kill & $\begin{array}{l}\text { Paulins Kill at Blairstown, N.J. } \\
\quad(01443500)\end{array}$ & 405851 & 0745712 & 126 & $\begin{array}{l}\text { 1922-2014 } \\
\text { incomplete record for water year } 1977\end{array}$ \\
\hline Pequest River & $\begin{array}{l}\text { Pequest River at Pequest, N.J. } \\
(01445500)\end{array}$ & 404950 & 0745840 & 106 & $1922-2014$ \\
\hline
\end{tabular}




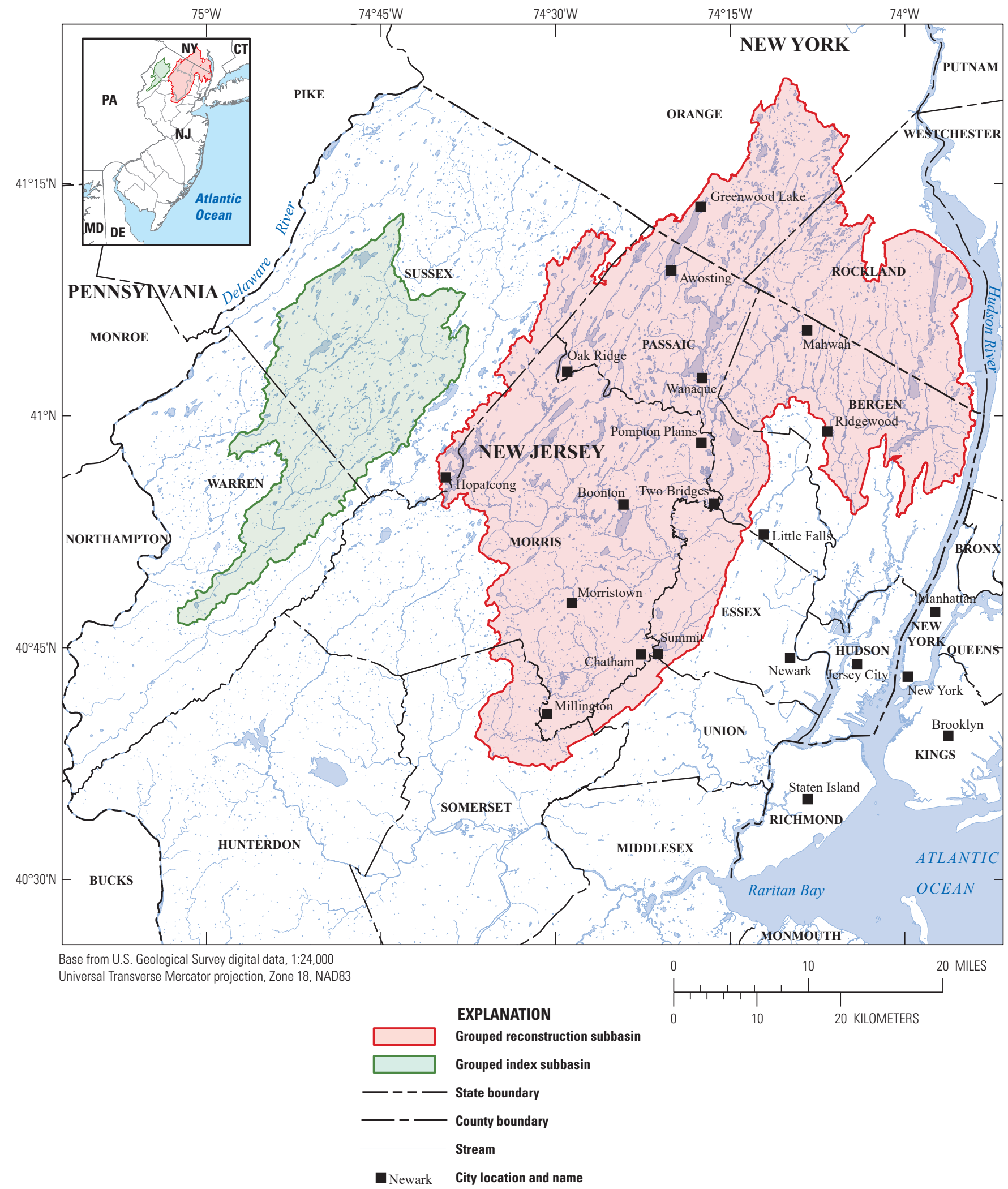

Figure 1. Groups of reconstruction subbasins and index subbasins in northern New Jersey and southeastern New York. 


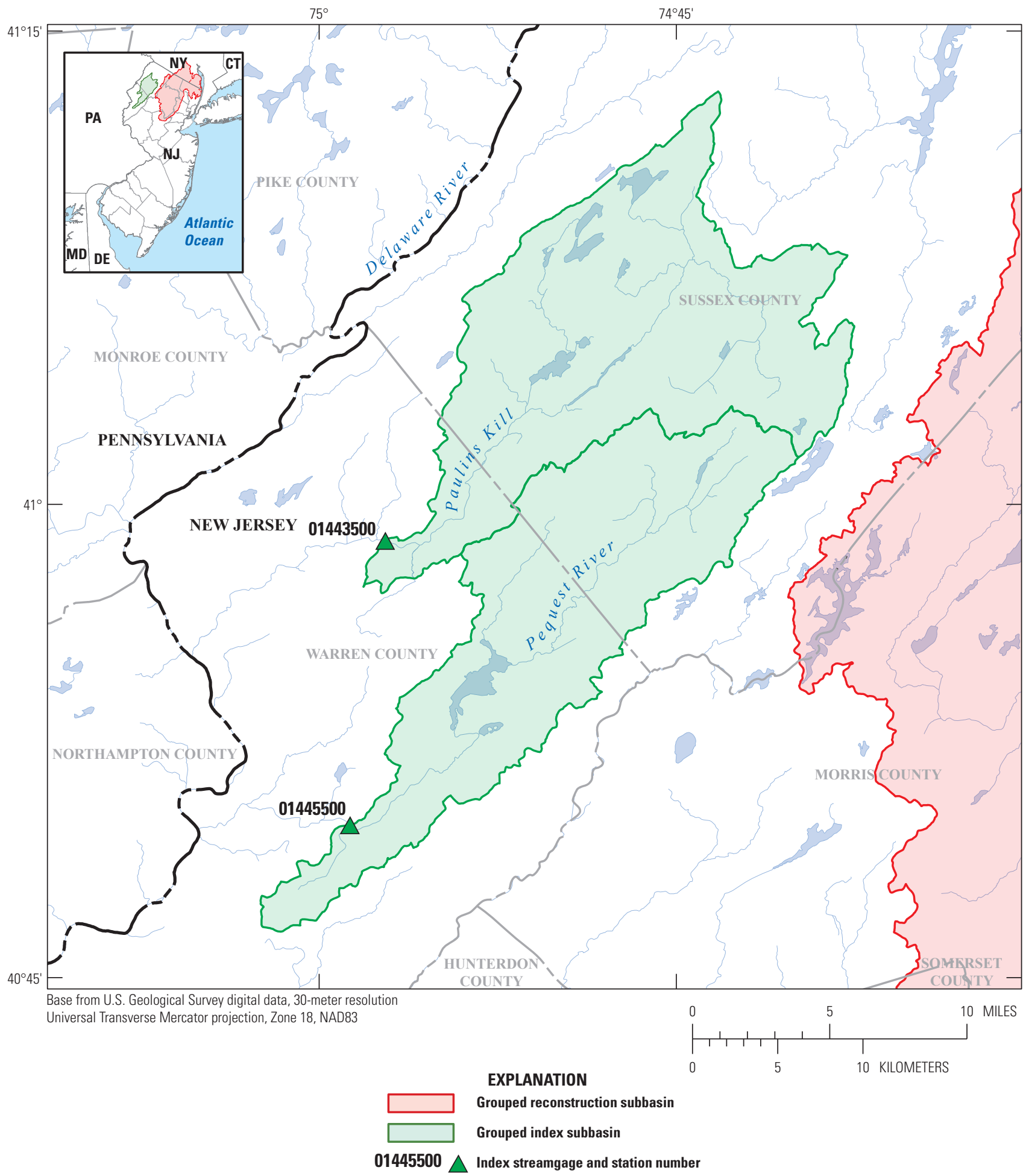

Figure 2. Index subbasins and index gages in northern New Jersey. 


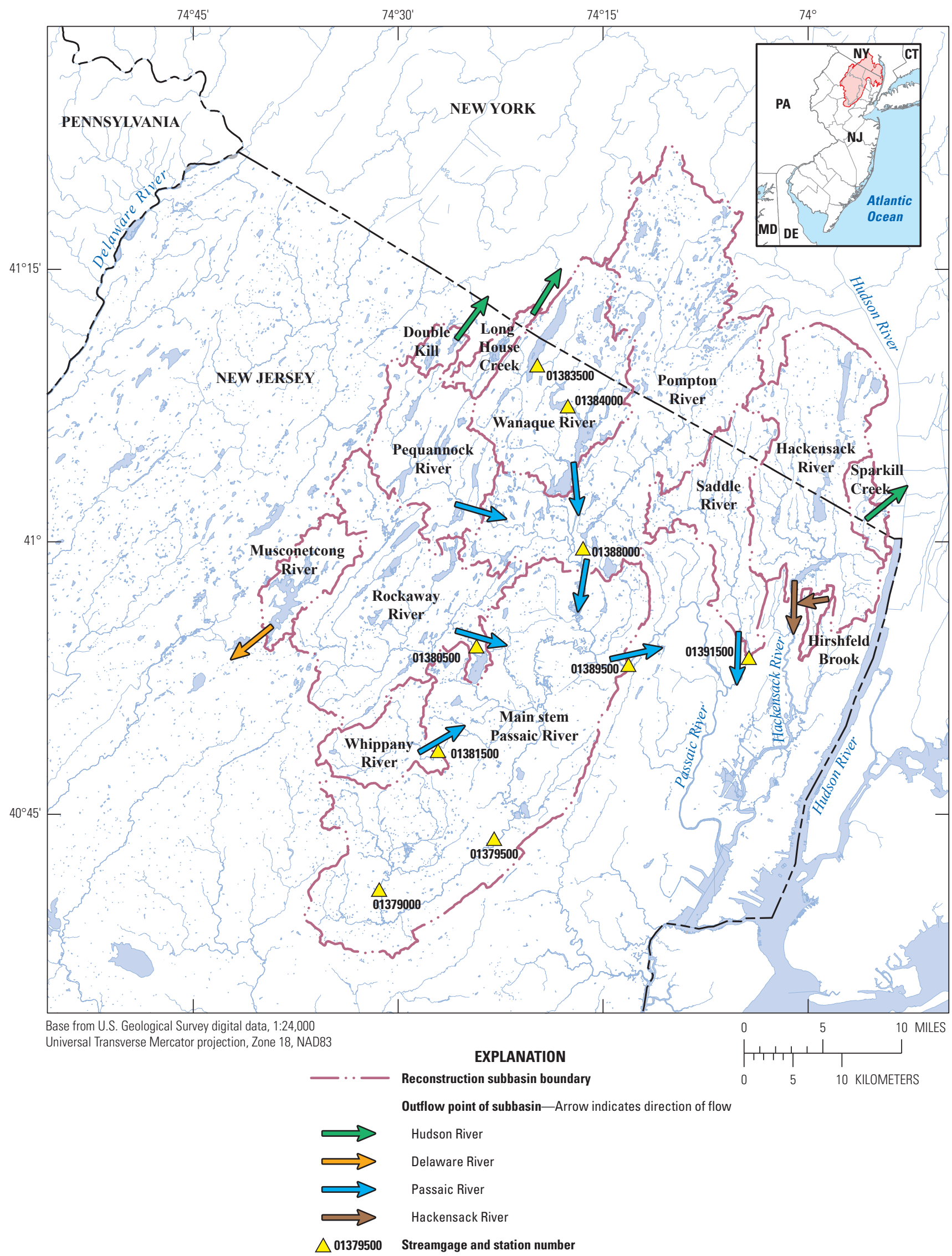

Figure 3. Reconstruction subbasins, outlets of each subbasin, and selected streamgages used to disaggregate monthly reconstructed streamflows in northern New Jersey and southeastern New York. 


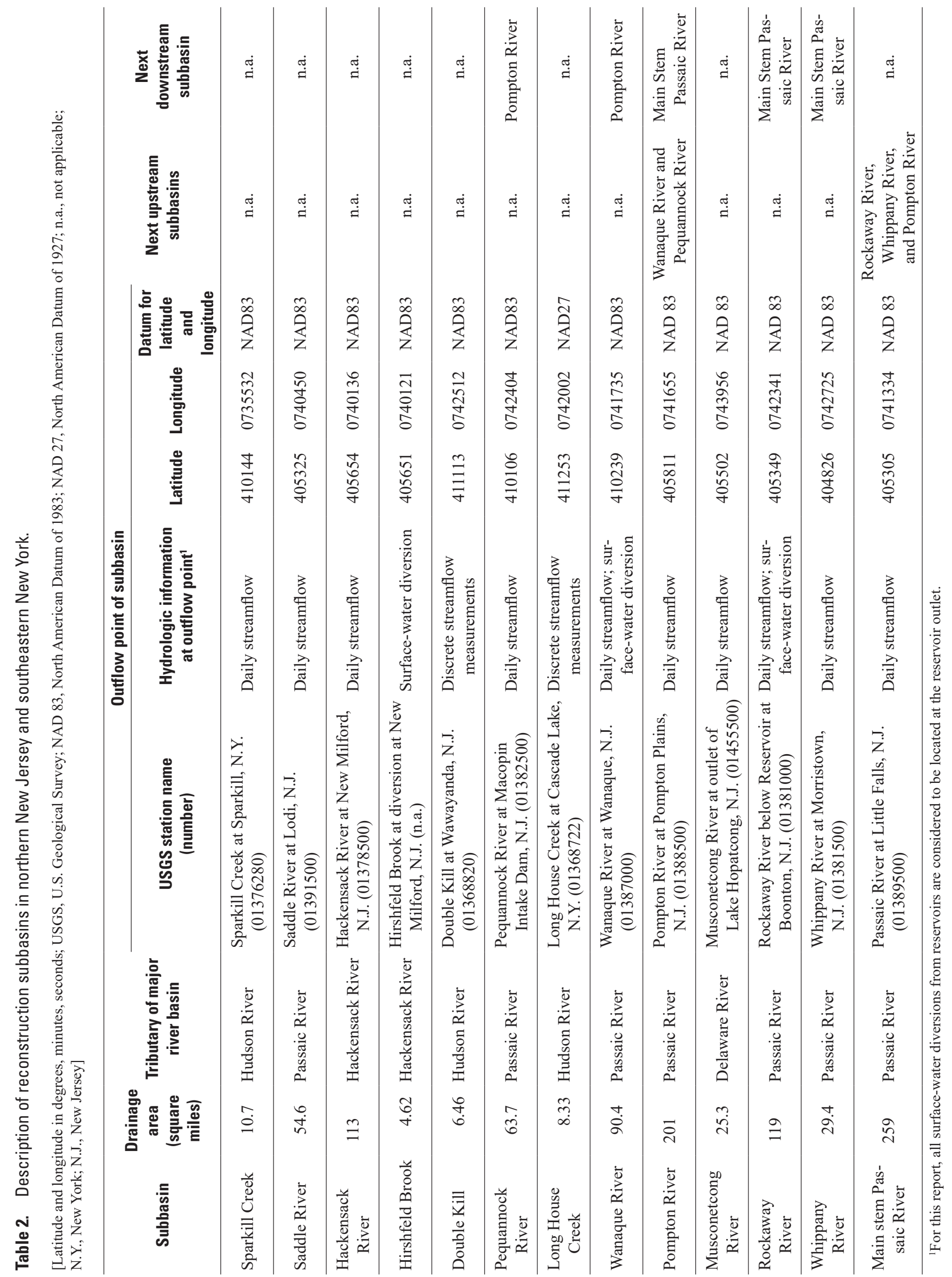


diversions from reservoirs were considered to occur at the reservoir outlet.

Detailed maps of the reconstruction subbasins are presented in figures 4 (Hackensack River, Saddle River, Hirshfeld Brook, and Sparkill Creek), 5 (Pequannock River and Double Kill), 6 (Wanaque River and Long House Creek), 7 (Pompton River), 8 (Rockaway River, Musconetcong River, and Whippany River), and 9 (Main Stem Passaic River). The maps show some or all of the following selected features: reservoirs, surface-water diversions transferring water out of the subbasin, continuous-record streamgages, partial-record stations, and the flow-reconstruction sites. Surface-water diversions transferring water into a subbasin are not shown.

\section{Reservoirs}

Reservoirs included in this analysis were selected because information on end-of-month storage was available (table 3, figs. 4-9); reservoirs are identified by short names. Information for some small reservoirs or those without known operations of storage change shown in maps and (or) mentioned in the text was not used in the analysis.

\section{Surface-Water Diversions}

A diversion is the taking of water from a stream or other body of water into a canal, pipe, or other conduit (Langbein and Iseri, 1960). For this report, diversions include those features that remove water from a surface-water body (either a stream or reservoir) for either (1) transfer into another stream channel or reservoir or (2) treatment and distribution for use. Only surface-water diversions by selected water purveyors and the NJDEP were included in this analysis; surface-water diversions by other entities and all groundwater diversions were not included.

Twenty-six surface-water diversions were included in this study (table 4, figs. 4-9). These are or have been operated by eight water purveyors and the NJDEP. In this report, diversions are identified with a diversion index number. Most, but not all, diversions have an associated USGS station number.

Two types of surface-water diversions are considered in this report - pipe and dam (table 4, figs. 4-9). Of the 26 surface-water diversions considered, 22 are pipe diversions, and 4 are dam diversions. A pipe diversion is defined as the taking of water from a reservoir or stream channel through a pipe by the action of pumping or gravity. Dam diversions are those that transfer water out of one stream channel and into an adjacent stream channel as the result of the installation of a weir (a low dam) in the first stream channel.

\section{Streamgages}

Records for 27 selected streamgages (table 5, figs. 4-9) were used to reconstruct streamflows. A streamgage is a facility that measures and records continuous streamflow. The streamflow measured at streamgages is labeled "observed." Streamgages mentioned in the study are or were operated by the USGS and are identified by name and station number.

\section{Partial-Record Stations}

Discrete measurements of observed streamflow at six partial-record stations (table 6, figs. 4-9) were used to determine reconstructed streamflows at some sites. Partial-record stations are locations where discrete measurements of streamflow have been systematically collected over time to answer a particular question. All partial-record stations mentioned in this study were established and operated by the USGS; these stations are identified by the station name and number.

\section{Flow-Reconstruction Sites}

Flow-reconstruction sites are those locations for which reconstructed flows were determined (table 7, figs. 4-9). Most sites were selected by the New Jersey Geological and Water Survey (part of the New Jersey Department of Environmental Protection) to provide information for the RiverWare model. Nearly all sites are at streamgages, reservoir outlets, or points of diversion. A few sites at streamgages in the Rockaway River (Recon41), Whippany River (Recon44, Recon45), and Passaic River (Recon49) subbasins were added by the USGS, most of them to help determine reconstructed flows at sites selected by the NJDEP. Flow-reconstructions sites are identified by name and index number.

\section{Description of Selected Features in Each Reconstruction Subbasin}

The discussion of selected features is organized into groups of reconstruction subbasins adjacent to one another. Features presented include surface-water diversions, reservoirs, streamgages, partial-record stations, and flow-reconstruction sites.

\section{Hackensack River, Saddle River, Hirshfeld Brook, and Sparkill Creek}

The subbasins of the Hackensack River, Saddle River, Hirshfeld Brook, and Sparkill Creek are in the eastern part of the group of reconstruction subbasins (fig. 3). Features of the Hackensack River subbasin (fig. 4) include 4 reservoirs (table 3), 3 pipe diversions (table 4), 4 streamgages (table 5), and 7 flow-reconstruction sites (table 7). Three of the reservoirs-DeForest Lake, Lake Tappan, and Oradell Reservoir-are on the Hackensack River; the fourth reservoir, Woodcliff Lake, is on Pascack Brook, a tributary to the Hackensack River. One pipe diversion transfers water out of each of the following: DeForest Lake (Div02), the Hackensack River at West Nyack (Div03), and the Oradell Reservoir (Div04). Transferred water is treated and distributed for use. Three of the four streamgages are on the Hackensack River at West Nyack, N.Y. (01376800); Rivervale, N.J. (01377000); and New Milford, N.J. (01378500). The remaining streamgage is on Pascack Brook at Westwood, N.J. (01377500).

Seven flow-reconstruction sites were designated for the Hackensack River subbasin (fig. 4, table 7). 
Flow-reconstruction sites share locations with the following streamgages: Hackensack River at West Nyack, N.Y. (Recon04); Hackensack River at Rivervale, N.J. (Recon06); Pascack Brook at Westwood, N.J. (Recon08); and Hackensack River at New Milford, N.J. (Recon09). The remaining sites are at the outlets of DeForest Lake (Recon03), Lake Tappan (Recon05), and Woodcliff Lake (Recon07).

Features of the Saddle River subbasin (fig. 4) consist of 1 pipe diversion (table 4), 4 streamgages (table 5), and 4 flow-reconstruction sites (table 7). The diversion Saddle River at Paramus, N.J. (Div06), transfers water into the Hackensack River subbasin. This water is pumped from the Saddle River between the diversion site and the streamgage at Saddle River below Hohokus Brook at Paramus, N.J. (01391102) and is transferred to the Musquapsink Brook, a tributary to Pascack Brook. The four streamgages are on the Saddle River at Upper Saddle River, N.J., (01390450); Ridgewood, N.J. (01390500); below Hohokus Brook at Paramus, N.J. (01391102); and Lodi, N.J. (01391500). The four flowreconstruction sites are on the Saddle River below diversion at Paramus, N.J. (Recon13), and at the streamgages at Upper Saddle River, N.J. (Recon11); Ridgewood, N.J. (Recon12); and below Hohokus Brook at Paramus, N.J. (Recon14).

Features of the Hirshfeld Brook subbasin (fig. 5) consist of 1 pipe diversion (table 4), 1 partial-record station (table 6), and 1 flow-reconstruction site (table 7). The pipe diversion (Div05) is at the downstream end of the subbasin and transfers water to the Oradell Reservoir in the Hackensack River subbasin. The partial-record station is at New Milford, N.J. (01378520), upstream from the diversion. The flow-reconstruction site (Recon10) is at the point of the pipe diversion.

Features of the Sparkill Creek subbasin (fig. 4) consist of 1 pipe diversion (table 4), 1 streamgage (table 5), and 2 flow-reconstruction sites (table 7). The pipe diversion, Sparkill Creek diversion at Northvale, N.J. (Div01; table 4), transfers water into the Hackensack River subbasin; water was pumped from Sparkill Creek and discharged into a tributary to Dorotockeys Run, which flows into the Oradell Reservoir. The streamgage on Sparkill Creek at Sparkill, N.Y. (01376280), at the downstream end of the subbasin was discontinued in water year 1978. Flow-reconstruction sites were designated at the site of the diversion (Recon01) and the discontinued streamgage (Recon02).

\section{Pequannock River and Double Kill}

The subbasins of the Pequannock River and Double Kill are in the northwestern part of the group of reconstruction subbasins (fig. 3). Features of the Pequannock River subbasin (fig. 5) include 5 reservoirs (table 3), 3 diversions (table 4), 1 streamgage (table 5), and 11 flow-reconstruction sites (table 7). The reservoirs are Canistear, Oak Ridge, Clinton, Charlotteburg, and Echo Lake. Storage in the other ponds in the subbasin was not included in the analysis. Two of the diversions are dam diversions. The dam diversion on the Pequannock River near Stockholm, N.J. (Div08), transferred water to the Canistear Reservoir through 1977. The other dam diversion, Mathews Brook diversion near Macopin, N.J. (Div10), transfers water from Mathews Brook to Echo Lake. The pipe diversion on the Charlotteburg Reservoir at Charlotteburg, N.J. (Div09), transfers water directly for treatment, then distribution to the City of Newark. The one streamgage is on the Pequannock River at the outlet of the subbasin at Macopin Intake Dam, N.J. (01382500).

There are 11 flow-reconstruction sites in the Pequannock River subbasin (table 7, fig. 5). One (Recon16) is at the site of the dam diversion on the Pequannock River to the Canistear Reservoir. Five sites are at the outlets of the selected reservoirs: Canistear Reservoir (Recon17), Oak Ridge Reservoir (Recon19), Clinton Reservoir (Recon22), Charlotteburg Reservoir (Recon23), and Echo Lake (Recon25). One site is at the dam diversion of Mathews Brook into Echo Lake (Recon24). Three sites are at outlets of the following ponds: Dunker Pond (Recon18), Hanks Pond (Recon20), and Cedar Pond (Recon21). The last flow-reconstruction site (Recon26) is at the streamgage on the Pequannock River at Macopin Intake Dam, N.J. (01382500), at the subbasin outlet.

The Double Kill subbasin (fig. 5) contains the following selected features: 1 discontinued pipe diversion (table 4), 1 partial-record station (table 6), and 1 flow-reconstruction site (table 7). The pipe diversion (Div07) transferred water from Lake Wawayanda to the Pequannock River subbasin during water years 1966 and 1980-81; water was pumped into Cherry Ridge Brook, a tributary to Canistear Reservoir in the Pequannock River subbasin. The partial-record station, Double Kill at Wawayanda, N.J. (01368820), is at the downstream end of the Double Kill subbasin. The flow-reconstruction site (Recon15) is on the Double Kill at the outlet of Wawayanda Lake.

\section{Wanaque River and Long House Creek}

The Long House Creek and Wanaque River subbasins are in the northern part of the group of reconstruction subbasins (fig. 3). Selected features of the Wanaque River subbasin (fig. 6) include 3 reservoirs (table 3), 2 pipe diversions (table 4), 3 streamgages (table 5), and 3 flow-reconstruction sites (table 7). The three reservoirs are Greenwood Lake, Monksville Reservoir, and Wanaque Reservoir. Both pipe diversions remove water from Wanaque Reservoir. One diversion transfers water for treatment and distribution for use (Div12), and the other transfers water to Oradell Reservoir in the Hackensack River subbasin (Div13). The three selected streamgages measure or have measured streamflow in the Wanaque River (table 5). The streamgages that measure the streamflow leaving Greenwood Lake at Awosting, N.J. (01383500), and the streamflow downstream from the Wanaque Reservoir at Wanaque, N.J. (01387000), are currently (2018) in operation. The third streamgage at Monks, N.J. (01384000), operated until water year 1985 when it was removed prior to the construction of the Monksville Reservoir. The three flow-reconstruction sites are at the sites of the streamgages at Awosting, N.J. (Recon29); Monks, N.J. (Recon30); and Wanaque, N.J. (Recon31). 
The Long House Creek subbasin (fig. 6) contains the following selected features: 1 dam diversion (table 4), 2 partial-record stations (table 6), and 2 flow-reconstruction sites (table 7). The dam diversion, Auxiliary outlet of Upper Greenwood Lake at Moe, N.J. (Div11), transfers water from the Long House Creek subbasin into the Wanaque River subbasin; water is released into Green Brook, then flows into Greenwood Lake. The partial-record station at this location (01368720) measures the amount of this transfer. The other partial-record station on the Long House Creek below Cascade Lake, N.Y. (01376822), measures the amount of streamflow in Long House Creek at the outlet of the Long House Creek subbasin downstream from Upper Greenwood Lake. The two flow-reconstruction sites (table 7) are at the diversion from Upper Greenwood Lake at Moe into Green Brook (Recon27) and on Long House Creek at the outlet from Upper Greenwood Lake (Recon28).

\section{Pompton River}

The Pompton River subbasin is in the central part of the group of reconstruction subbasins (fig. 3). The Pompton River subbasin contains reaches of the following streams: Ramapo River, Pequannock River, Wanaque River, Posts Brook, Stone House Brook, Haycock Brook, and Pompton River (fig. 7). The Ramapo, Pequannock, and Wanaque Rivers and Haycock Brook are all tributaries to the Pompton River. Stone House Brook is a tributary to the Pequannock River, and Posts Brook is a tributary to the Wanaque River.

Storage at the two reservoirs mentioned in the discussion of this subbasin-Point View Reservoir and Butler Reservoir-were not included in the analysis. Point View Reservoir is on Haycock Brook, and Butler Reservoir is on Stone House Brook.

Selected features of the Pompton River subbasin (fig. 7) include 5 diversions (table 4), 3 streamgages (table 5), 2 partial-record stations (table 6), and 6 flow-reconstruction sites (table 7). Four of the diversions are pipe diversions. Two of the pipe diversions transfer water out of the Ramapo River at Pompton Lakes. One (Div15) transfers water to the Wanaque Reservoir in the Wanaque River subbasin, and the other (Div16) transfers water to the Oradell Reservoir in the Hackensack River subbasin. The third pipe diversion (Div18) transfers water out of the Pompton River to the Point View Reservoir on Haycock Brook in the subbasin. The fourth pipe diversion (Div17) transfers water from the Point View Reservoir to the Passaic Valley Water Commission at Wayne. The fifth diversion is a dam diversion (Div14), which transfers water from Posts Brook into the Wanaque Reservoir in the Wanaque River subbasin.

The two partial-record stations in the Pompton River subbasin are on Posts Brook (table 6, fig. 7). The Posts Brook diversion to Wanaque Reservoir near Wanaque, N.J. (01387020), measures the amount of diversion to the Wanaque Reservoir. The Posts Brook below Wanaque diversion near Wanaque, N.J. (01387021), measures streamflow in Posts Brook downstream from the diversion.
There are six flow-reconstruction sites in the Pompton River subbasin (table 7, fig. 7). One site is on Stone House Brook at the outlet of Butler Reservoir, N.J. (Recon32). Two sites are on Posts Brook; one (Recon33) is upstream from the diversion to Wanaque Reservoir, and the other (Recon34) is the diversion. One site is on Haycock Brook at the outlet of Point View Reservoir (Recon36). The remaining two sites are at the streamgages on the Ramapo River at Pompton Lakes, N.J. (Recon35), and on the Pompton River at Pompton Plains, N.J. (Recon37).

\section{Rockaway River, Musconetcong River, and Whippany River}

The subbasins of the Rockaway, Musconetcong, and Whippany Rivers are in the western part of the group of reconstruction subbasins (fig. 3). The Rockaway River subbasin contains the following streams: Rockaway River, Beaver Brook, and Stony Brook (fig. 8). Beaver Brook and Stony Brook are tributaries to Rockaway River. Selected features of the Rockaway River subbasin include 2 reservoirs (table 3 ), 1 pipe diversion (table 4), 3 streamgages (table 5), and 4 flowreconstruction sites (table 7). The two reservoirs are Boonton Reservoir on the Rockaway River and Splitrock Reservoir on Beaver Brook. The one pipe diversion (Div20) transfers water from the Boonton Reservoir outside the basin to Jersey City for treatment and distribution for use. The three streamgages are on Beaver Brook downstream from the outlet of Splitrock Reservoir, N.J. (01380000); Rockaway River above the Reservoir at Boonton, N.J. (01380500); and Rockaway River below the Reservoir at Boonton, N.J. (01381000). The flow-reconstruction sites are at the streamgage on Beaver Brook (Recon39); the Stony Brook tributary at the outlet of Taylortown Reservoir, N.J. (Recon40); the streamgage on the Rockaway River above the Reservoir at Boonton, N.J. (Recon41); and the streamgage on the Rockaway River below Reservoir at Boonton, N.J. (Recon42).

Selected features of the Musconetcong River subbasin (fig. 8) include Lake Hopatcong (table 3), 1 pipe diversion (table 4), 1 streamgage (table 5), and 1 flow-reconstruction site. The diversion (Div19) was used to transfer water from Lake Hopatcong to the Rockaway River subbasin during 1965-66 and 1980-81. The streamgage is on the Musconetcong River at the outlet of Lake Hopatcong, N.J. (01455500), and at the outlet of the subbasin. The flow-reconstruction site is at the streamgage (Recon38).

Selected features of the Whippany River subbasin (fig. 8) include 2 streamgages (table 5) and 3 flow-reconstruction sites (table 7). The streamgages are on the Whippany River near Morristown, N.J. (01381400), and the Whippany River at Morristown, N.J. (01381500). The flow-reconstruction sites are at the two streamgages on the Whippany River near Morristown, N.J. (Recon44), and at Morristown, N.J.(Recon45), and on Harmony Brook (a tributary to Whippany River) at the outlet of the Clyde Potts Reservoir (Recon43). Storage in Clyde Potts Reservoir was not included in the analysis because no records of storage were available. 


\section{Main Stem Passaic River}

The Main Stem Passaic River subbasin is the southernmost of the group of reconstruction subbasins (fig. 3), ending at Little Falls, N.J. This subbasin is bounded on the upstream and downstream extents by streamgages (table 5, fig. 9). The following streamgages are at the upstream extents: Pompton River at Pompton Plains, N.J. (01388500); the Rockaway River below Reservoir at Boonton, N.J. (01381000); and the Whippany River at Morristown, N.J. (01381500). The downstream boundary is at the streamgage on the Passaic River at Little Falls, N.J. (01389500). Reaches of the following streams are included in the subbasin: Whippany River, Rockaway River, Pompton River, Canoe Brook, and Passaic River. The first four streams are tributaries of the Passaic River.

Selected features of the Main Stem Passaic River subbasin (fig. 9) include 6 pipe diversions (table 4), 5 streamgages (table 5), and 8 flow-reconstruction sites. The diversions from the Passaic River near Summit, N.J. (Div21), and from Canoe Brook near Summit, N.J. (Div22), remove water for treatment and distribution. Diversions from the Pompton River transfer water to Wanaque Reservoir in the Wanaque River subbasin (Div23), to Oradell Reservoir in the Hackensack River subbasin (Div24); and to the Passaic Valley Water Commission at Wayne (Div25). The diversion at the Passaic River at Little Falls, N.J. (Div26), removes water for treatment and distribution. Records from the following streamgages were included in the analysis: Passaic River near Millington, N.J. (01379000); Passaic River near Chatham, N.J. (01379500); Canoe Brook near Summit, N.J. (01379530); Passaic River at Pine Brook, N.J. (01381900); and Passaic River at Little Falls, N.J. (01389500).

Flow-reconstruction sites are designated at eight locations in the Main Stem Passaic River subbasin (fig. 9, table 7). Three sites are designated at diversions on the Passaic River near Summit (Recon47), Canoe Brook at diversion near Summit (Recon48), and the Passaic River above Beatties Dam at Little Falls (Recon52). Three sites are at the streamgages at Passaic River near Chatham N.J. (Recon46); Passaic River at Pine Brook, N.J. (Recon49); and the Passaic River at Little Falls, N.J. (Recon53). The remaining two sites are on the Passaic River at Two Bridges, N.J. (Recon50), and the Pompton River at Two Bridges, N.J. (Recon51); these sites are just upstream from the junction of the Passaic and Pompton Rivers.

\section{Previous Studies}

There have been four reports in which daily reconstructed streamflows in the Passaic River Basin have been determined. Two unpublished reports describe the methods used to reconstruct daily streamflows at sites throughout the Passaic River Basin and use similar methods. Clinton Bogart Associates produced the report, "Documentation of Passaic River Basin daily natural flow data" (Clinton Bogart Associates, written commun., 1982), which presents reconstructed daily streamflows for water years 1920-79 at 14 sites by summing measured streamflows, changes in upstream reservoirs, and upstream surface-water diversions from purveyors. Missing values of reconstructed streamflows at a site were estimated from (1) linear regression between reconstructed streamflows at the site and streamflows at a selected streamgage or (2) from drainage-area adjustment of reconstructed streamflows at a selected streamgage.

Lawler, Matusky \& Skelly Engineers produced the report, "Jersey City Municipal Utilities Authority, reports on reservoir storage and safe yield" (Lawler, Matusky, and Skelly Engineers, written commun., 2004), which describes methods used to determine reconstructed streamflows at 10 sites in the Passaic River Basin during water years 1979-93. These methods also were described in a facsimile transmission from Don Distante of Lawler, Matusky \& Skelly Engineers to Ashgar Hasan, NJDEP, dated February 19, 1997. Reconstructed flows were determined by (1) summing measured streamflow, changes in reservoir storage, and the amount of surface-water diversions by purveyors leaving the basin, and then (2) subtracting from this sum the amount of water discharged by selected wastewater-treatment plants. Some values at selected sites were determined from drainage-area adjustment of reconstructed flows at other sites.

Dresnack and others (1984) estimated daily reconstructed streamflows at seven sites in the Passaic River Basin during 1921-81. Calculated values were determined by adjusting measured streamflow for reservoir storage changes and surface-water diversions by purveyors. Missing values of daily reconstructed flows at a site were determined using multiple linear regressions between calculated values of reconstructed flows at that site and daily streamflows at selected streamgages.

More recently, monthly and daily reconstructed flows at 34 sites in the basins of the Passaic, Hackensack, and Saddle Rivers were determined by Storck and Nawyn (2001); monthly reconstructed streamflows during water years 1993-96 and daily reconstructed streamflows for May 1, 1995, to October 31, 1995, were determined. Flows were reconstructed by adjusting measured streamflow for surfacewater and groundwater withdrawals from the basin (added to streamflow), net surface-water diversion into the basin (subtracted from streamflow), net groundwater diversion into the basin (subtracted from streamflow), changes in reservoir storage (added to streamflow), and wastewater-treatment-plant discharges reduced by the estimated infiltration and inflow into sewer lines (subtracted from streamflow). Missing streamflows were estimated by using either (1) multiple regression to correlate flows at different gages, (2) Maintenance of Variance Extension type 1 (MOVE1) relations (Hirsch, 1982), or (3) drainage-area adjustment. 


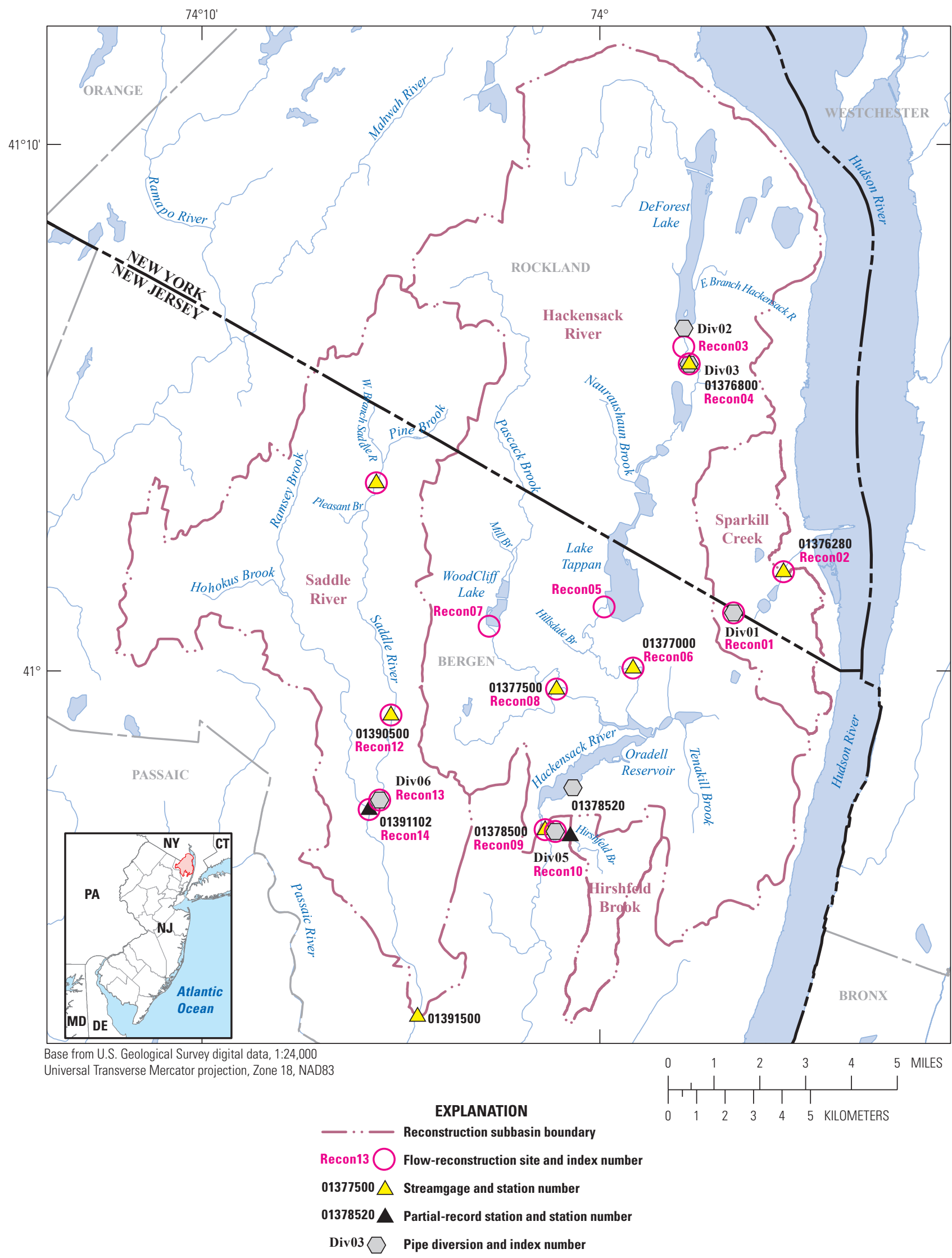

Figure 4. Selected features of the subbasins of the Hackensack River, Saddle River, Hirshfeld Brook, and Sparkill Creek in northern New Jersey and southeastern New York. 


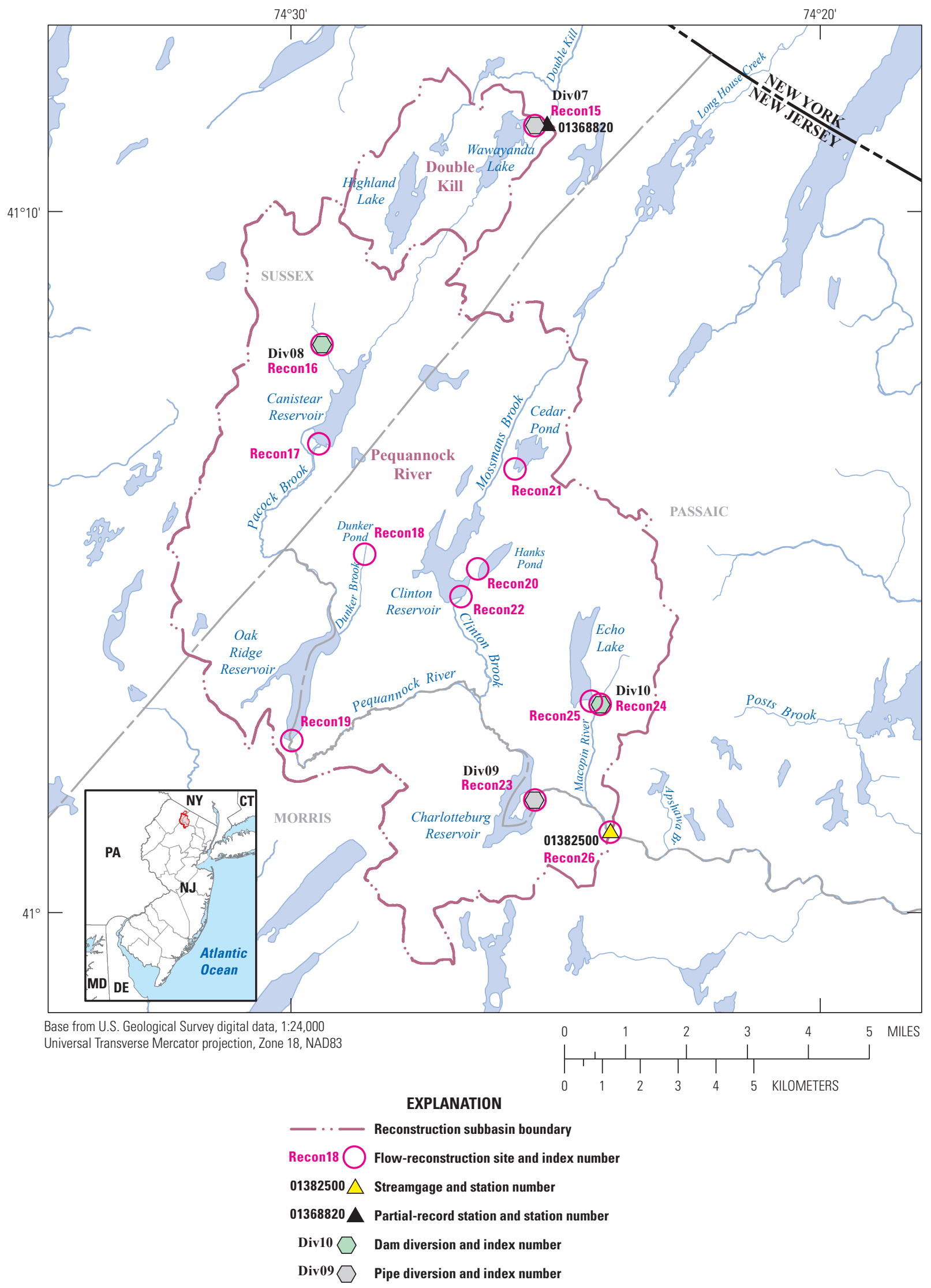

Figure 5. Selected features of the subbasins of the Pequannock River and Double Kill in northern New Jersey and southeastern New York. 


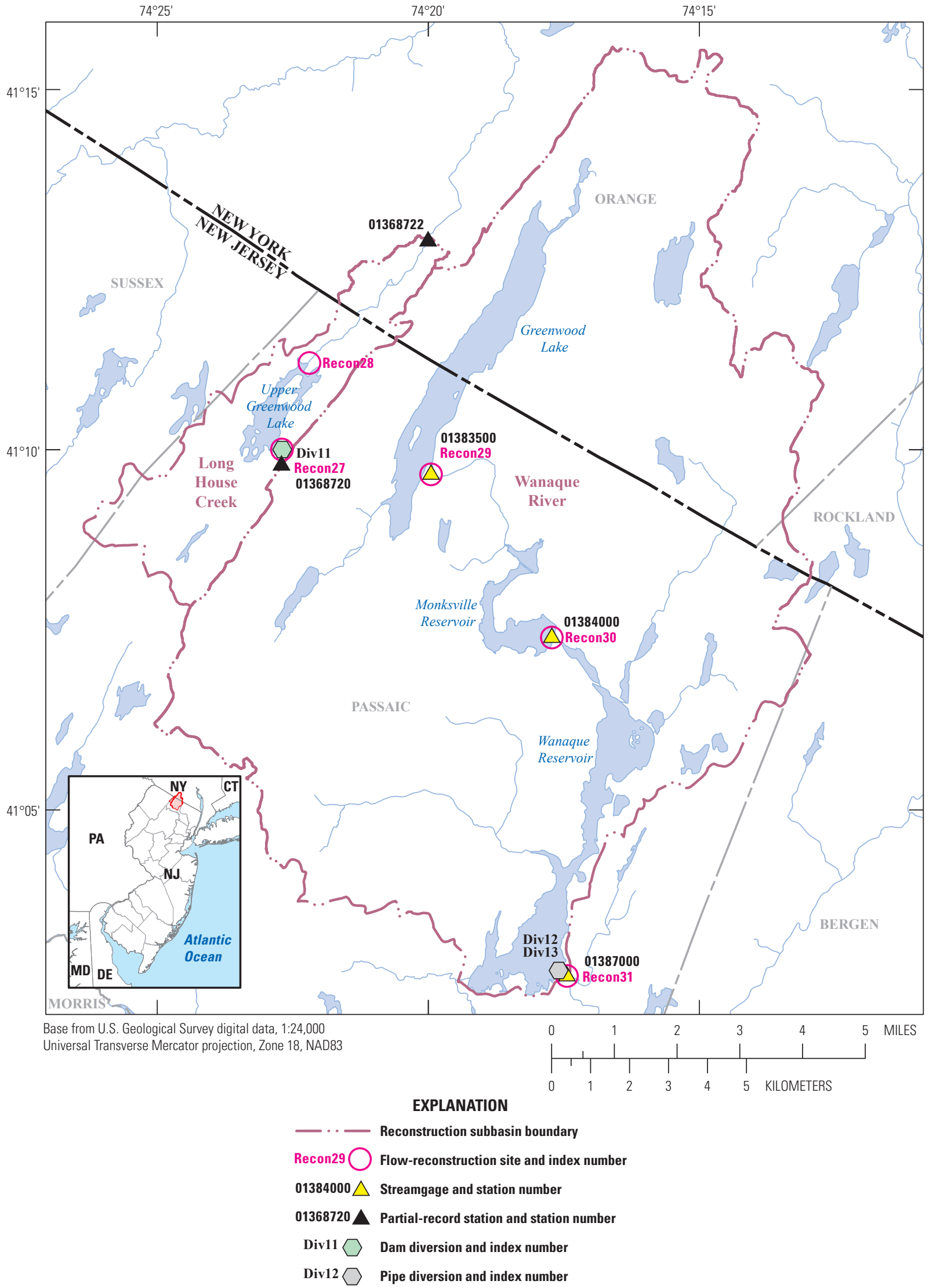

Figure 6. Selected features of the subbasins of the Wanaque River and Long House Creek in northern New Jersey and southeastern New York. 


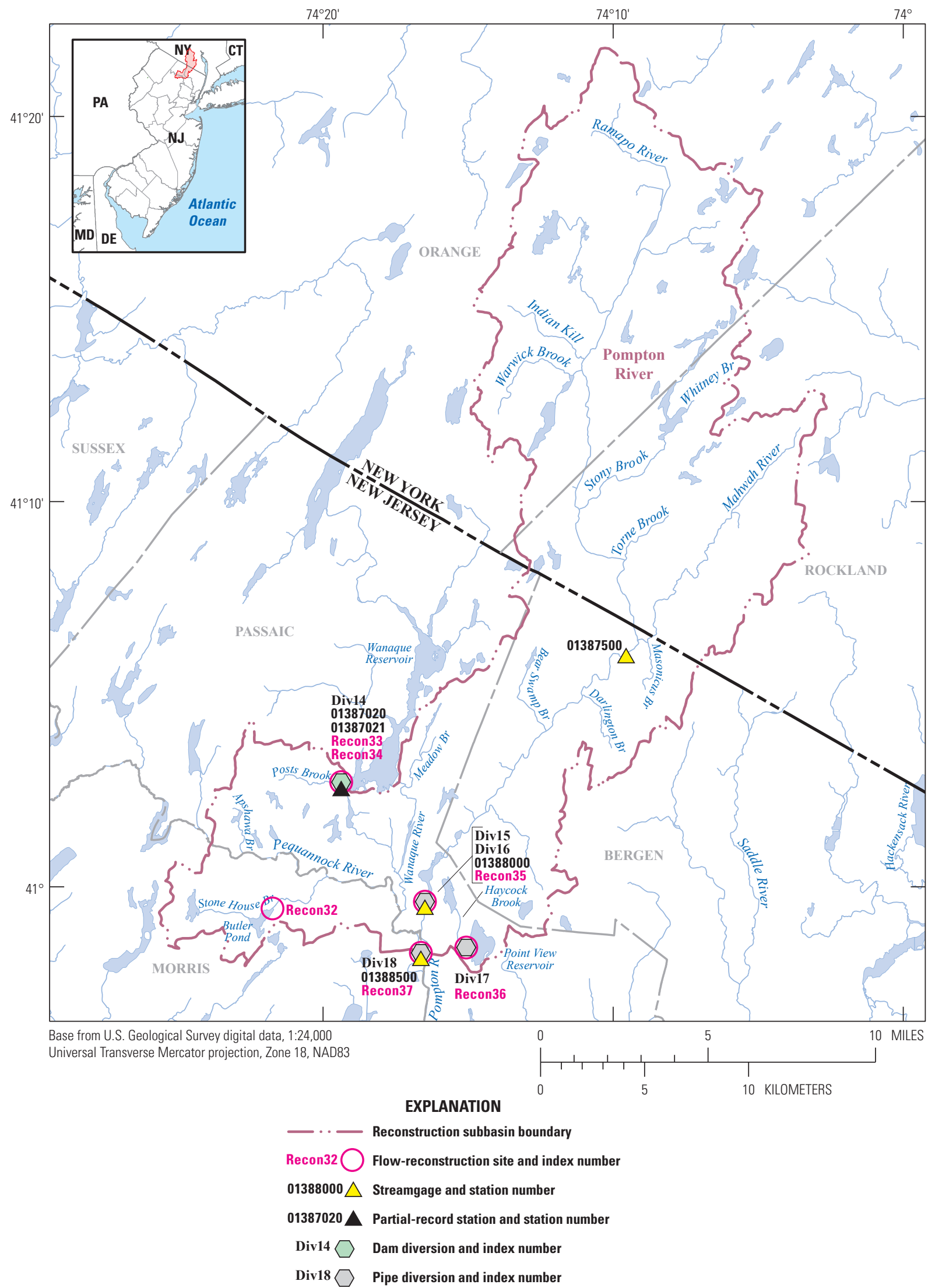

Figure 7. Selected features of the subbasin of the Pompton River in northern New Jersey and southeastern New York. 


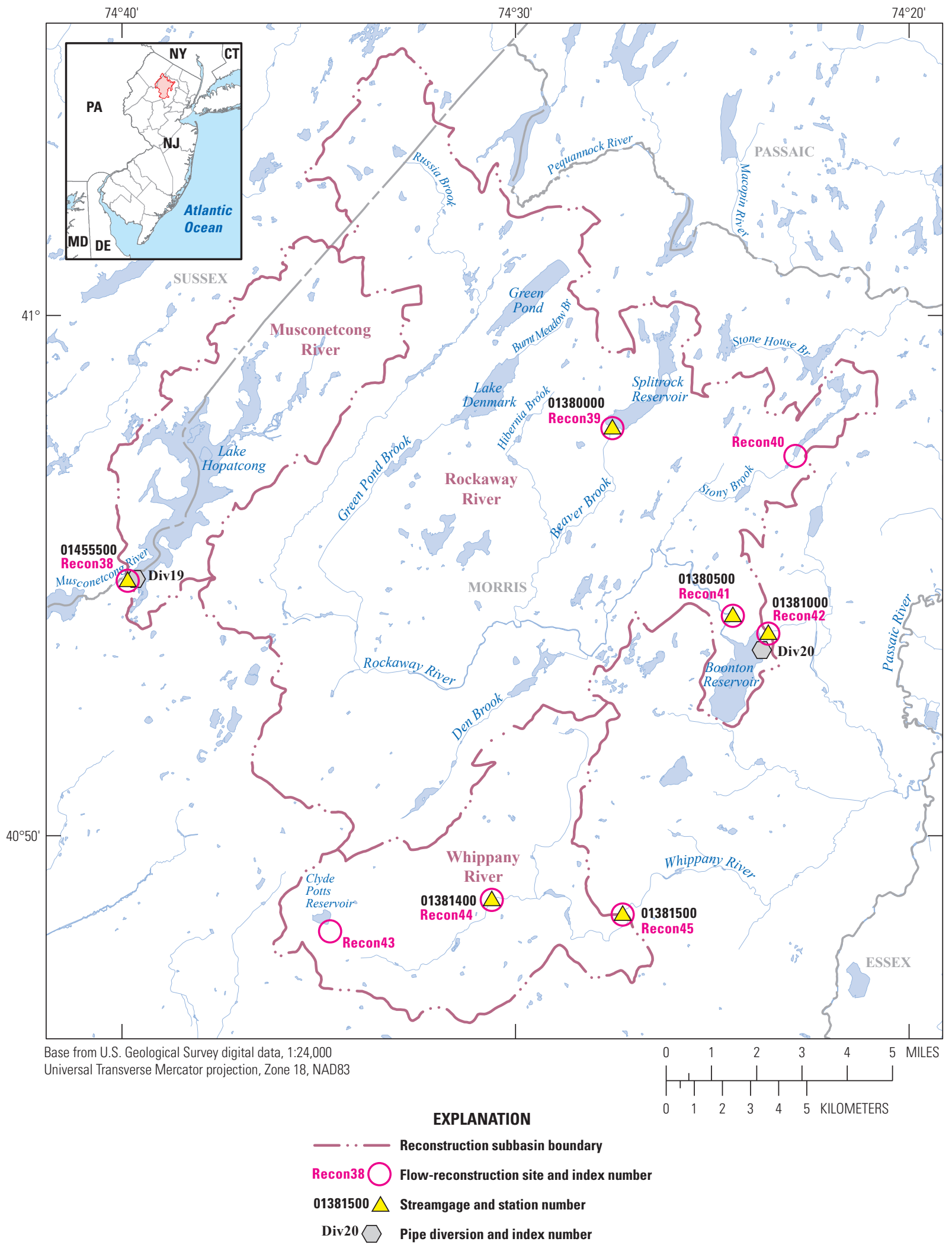

Figure 8. Selected features of the subbasins of the Rockaway River, Musconetcong River, and Whippany River in northern New Jersey. 


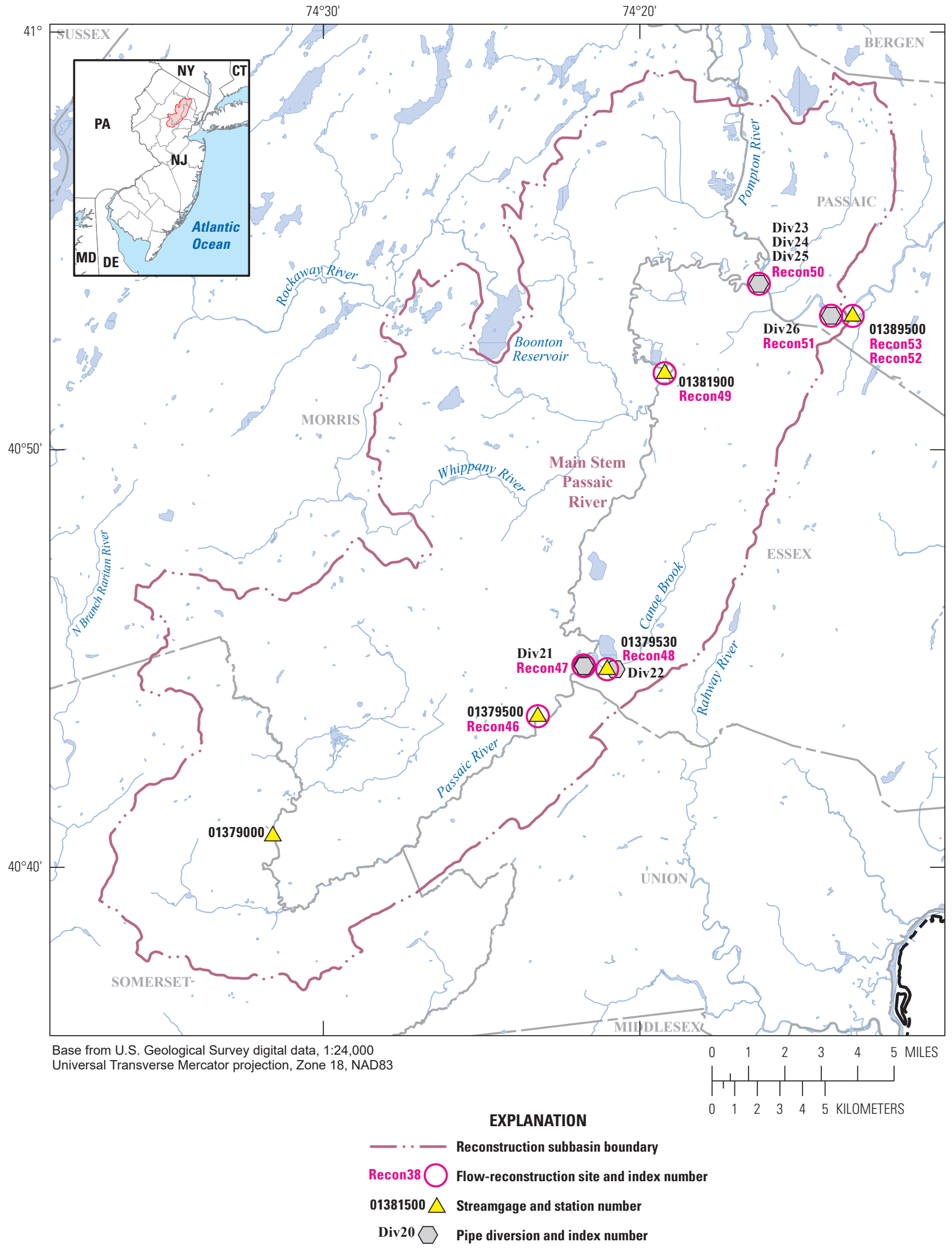

Figure 9. Selected features of the subbasin of the Main Stem Passaic River in northern New Jersey. 


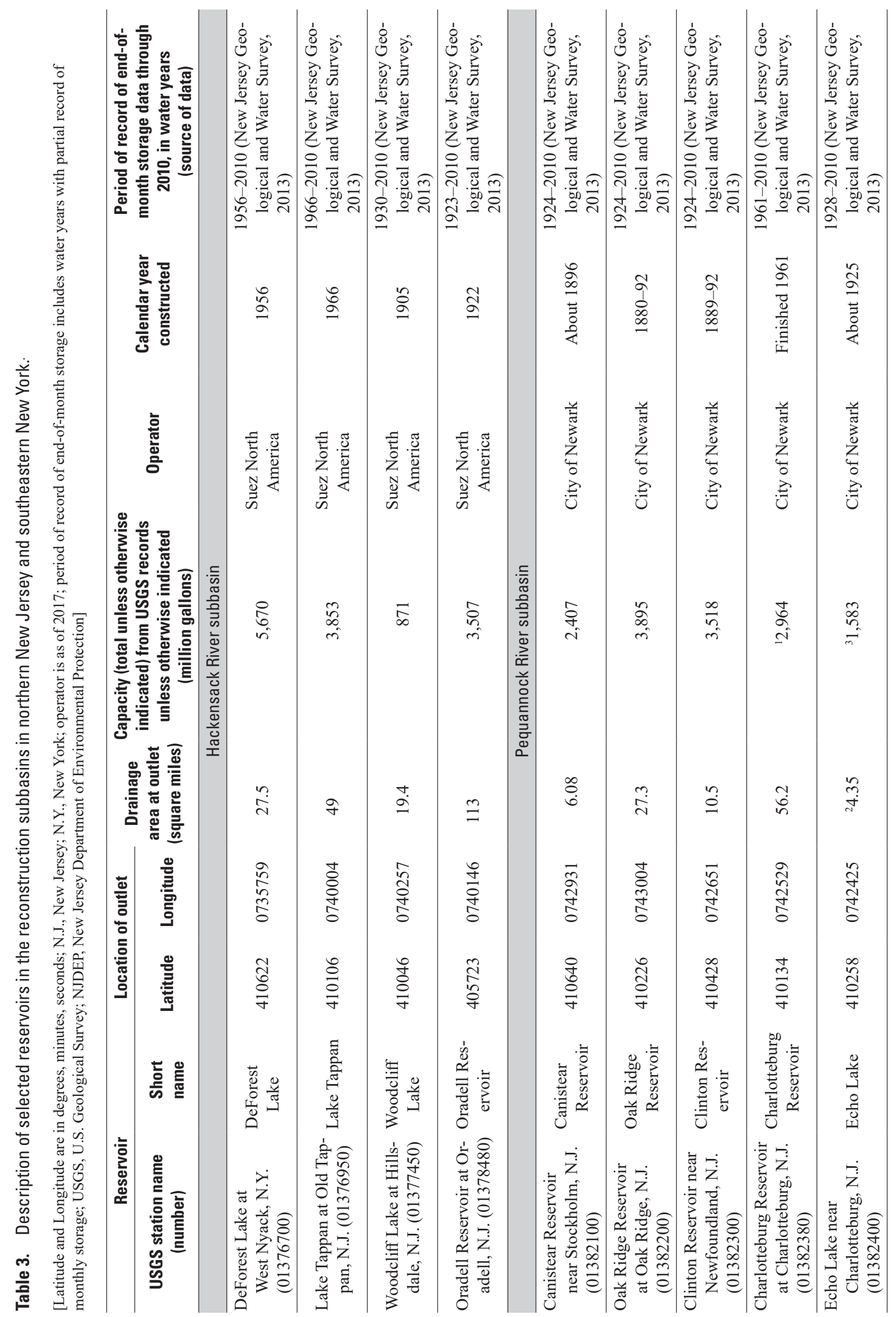




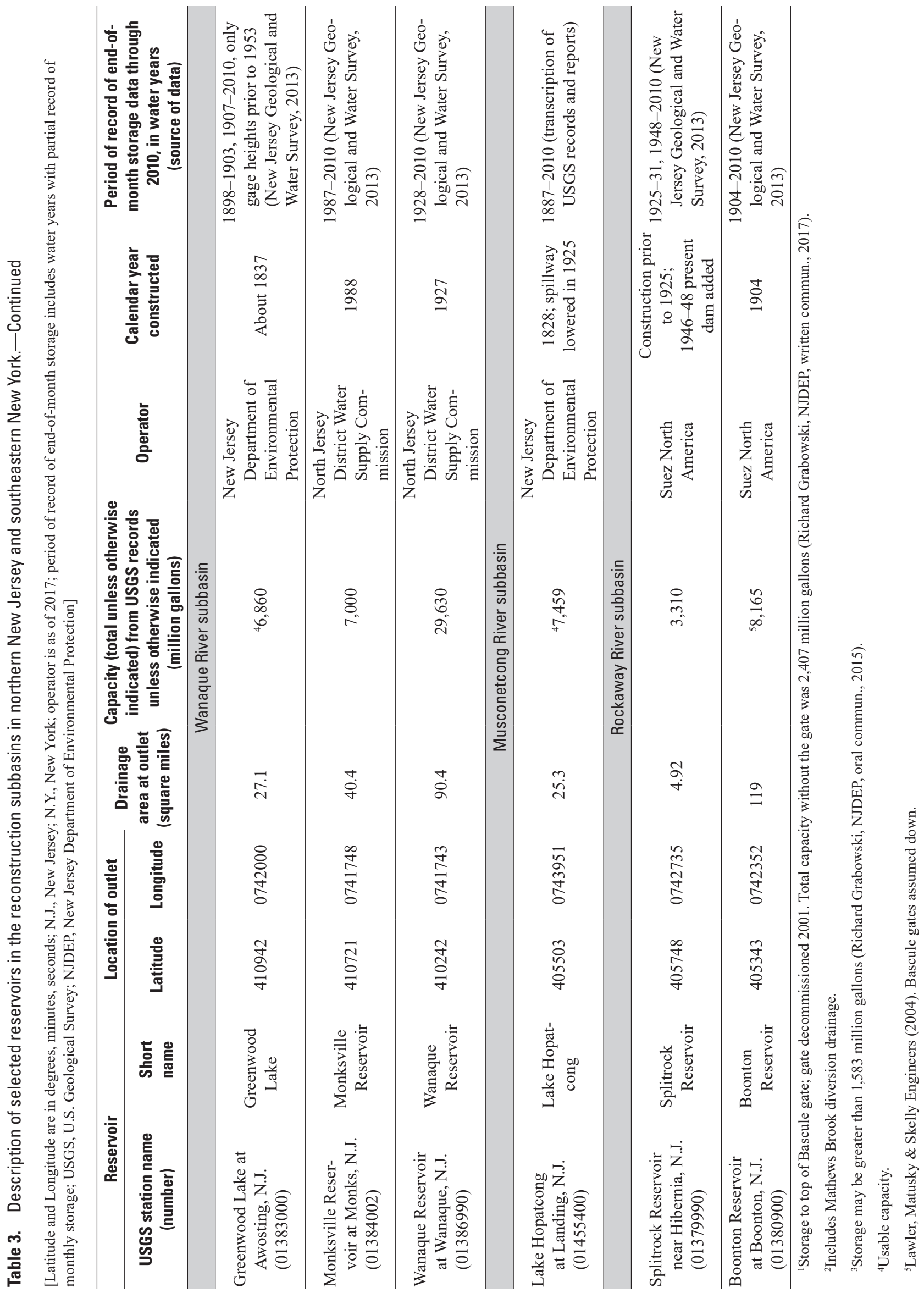



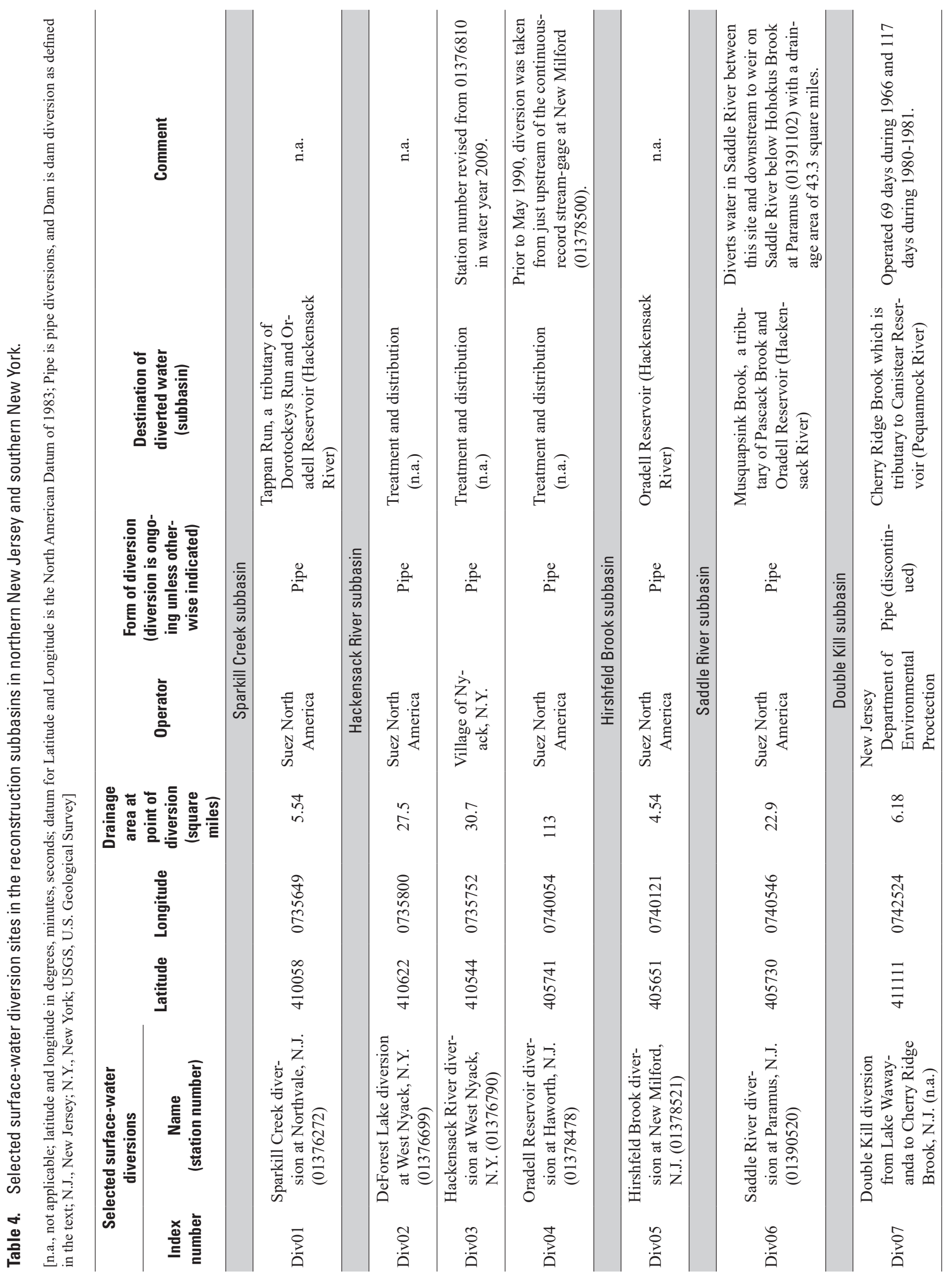


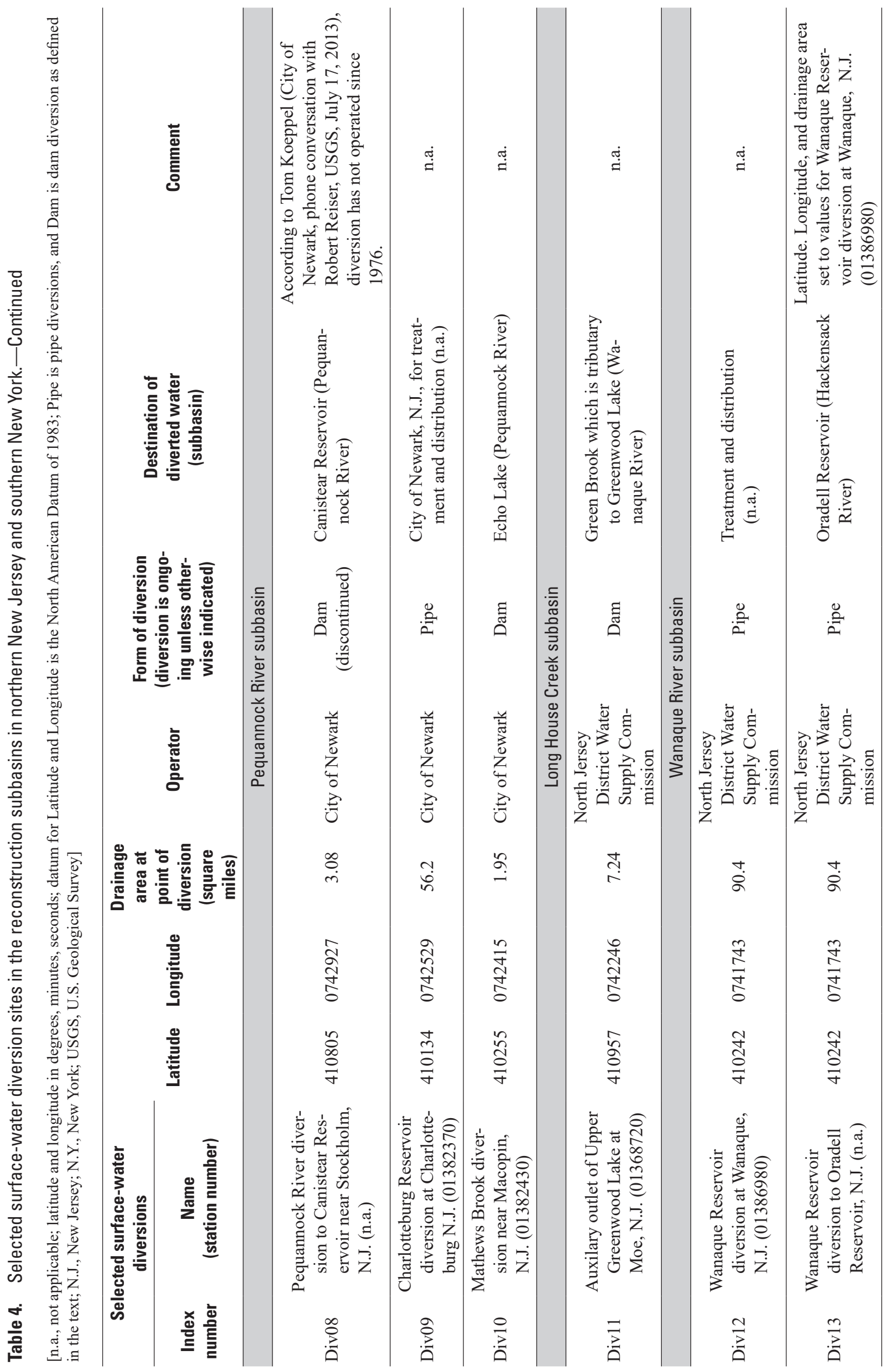




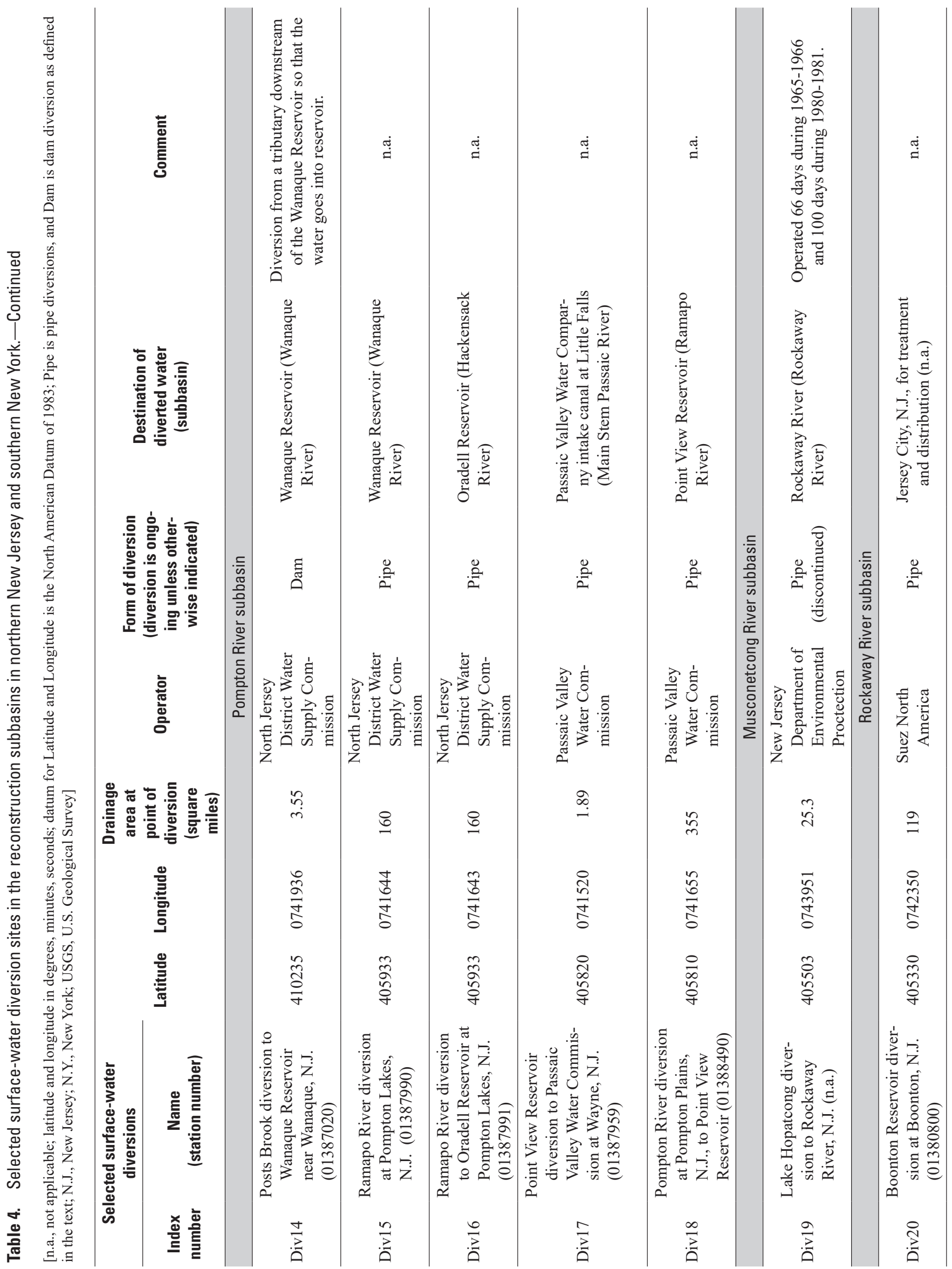




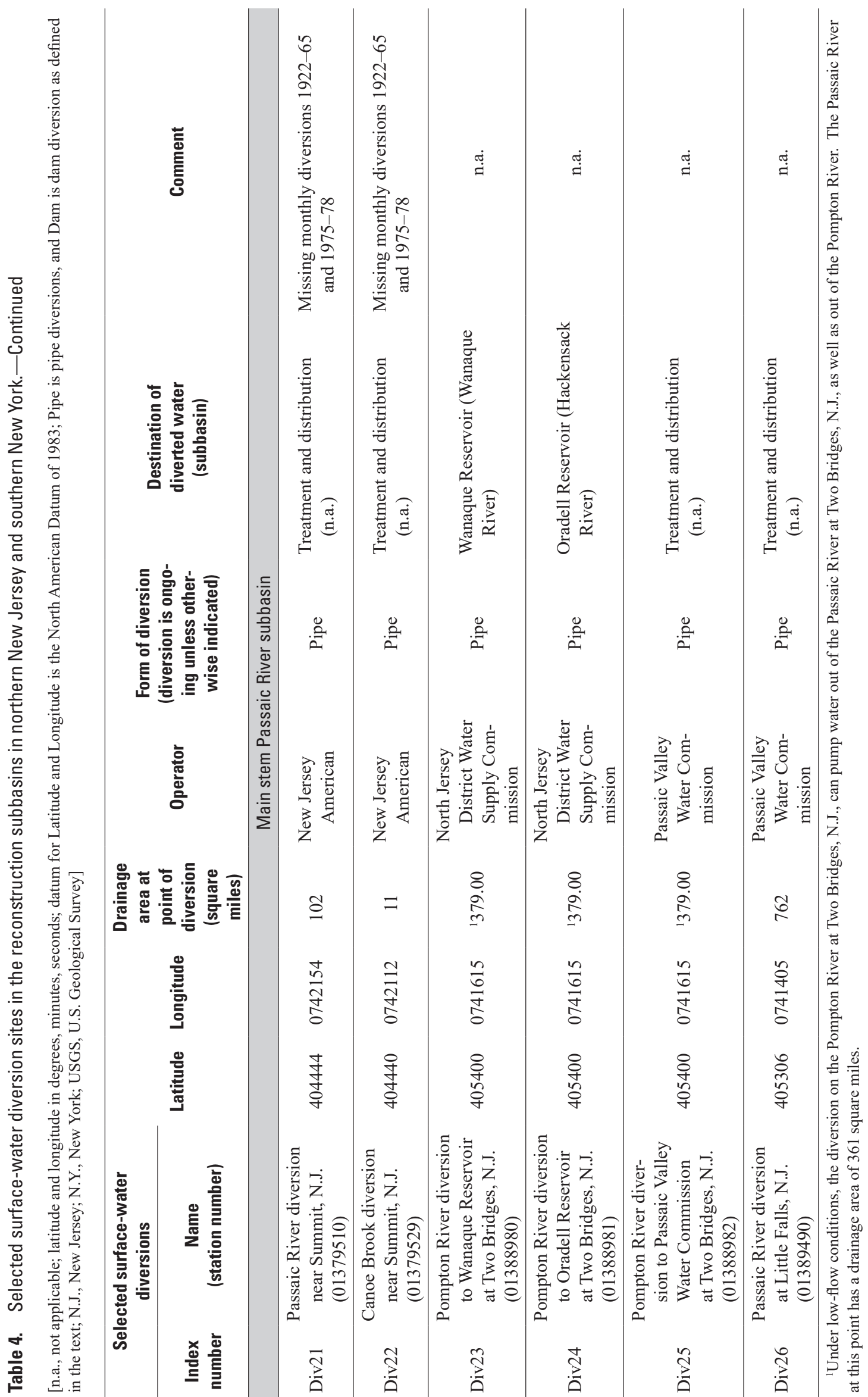


$$
\text { 흔 }
$$

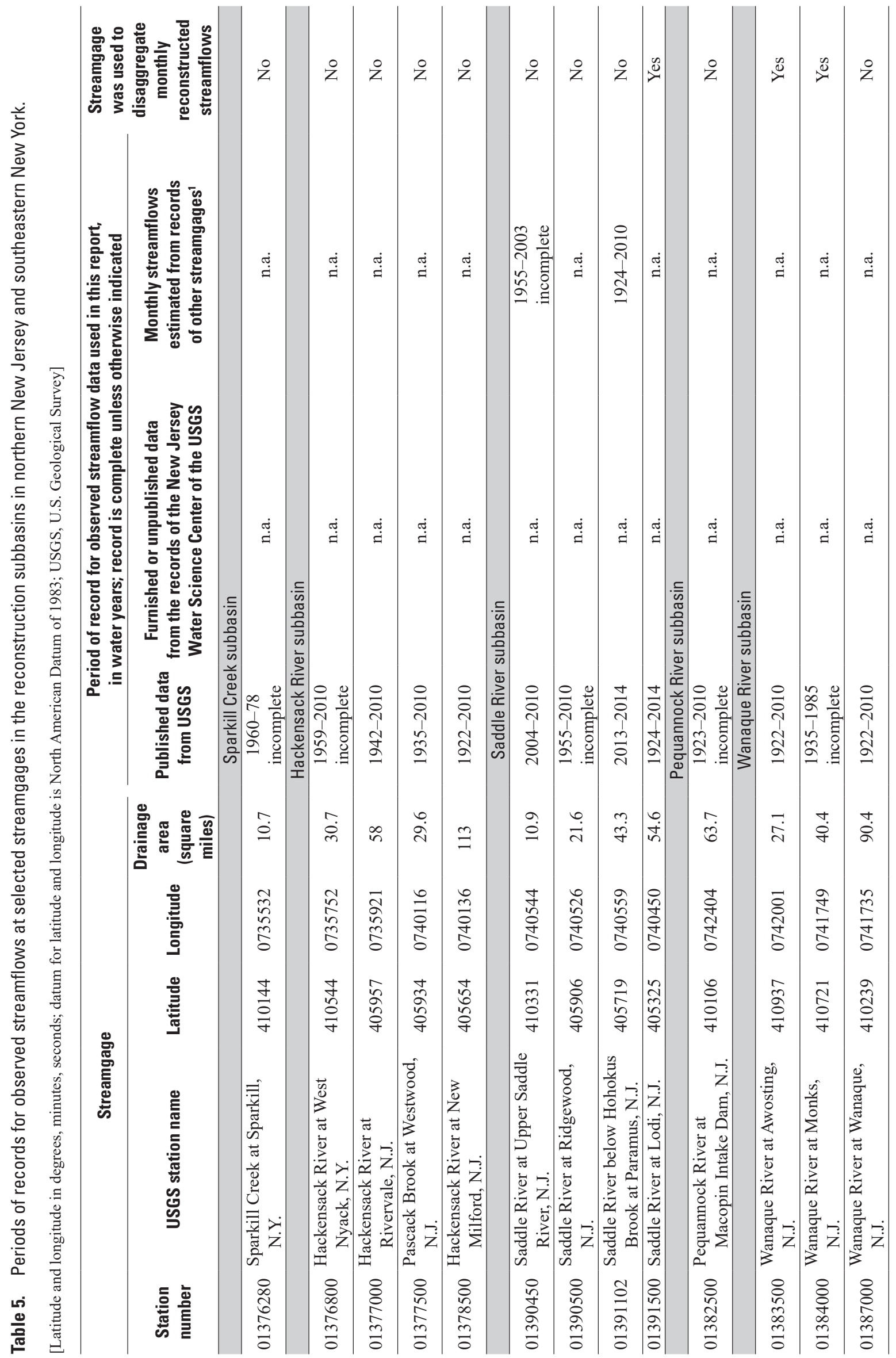




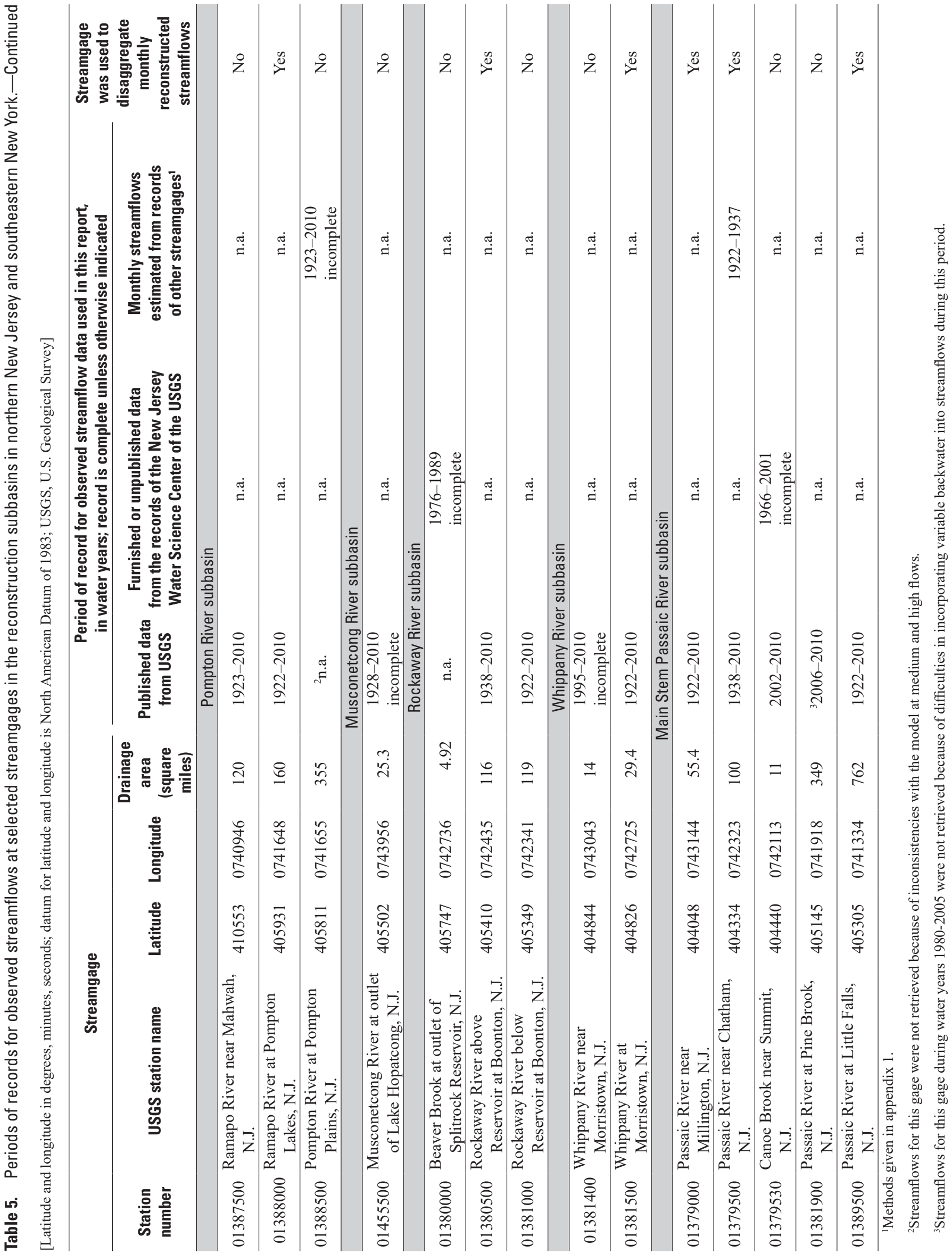




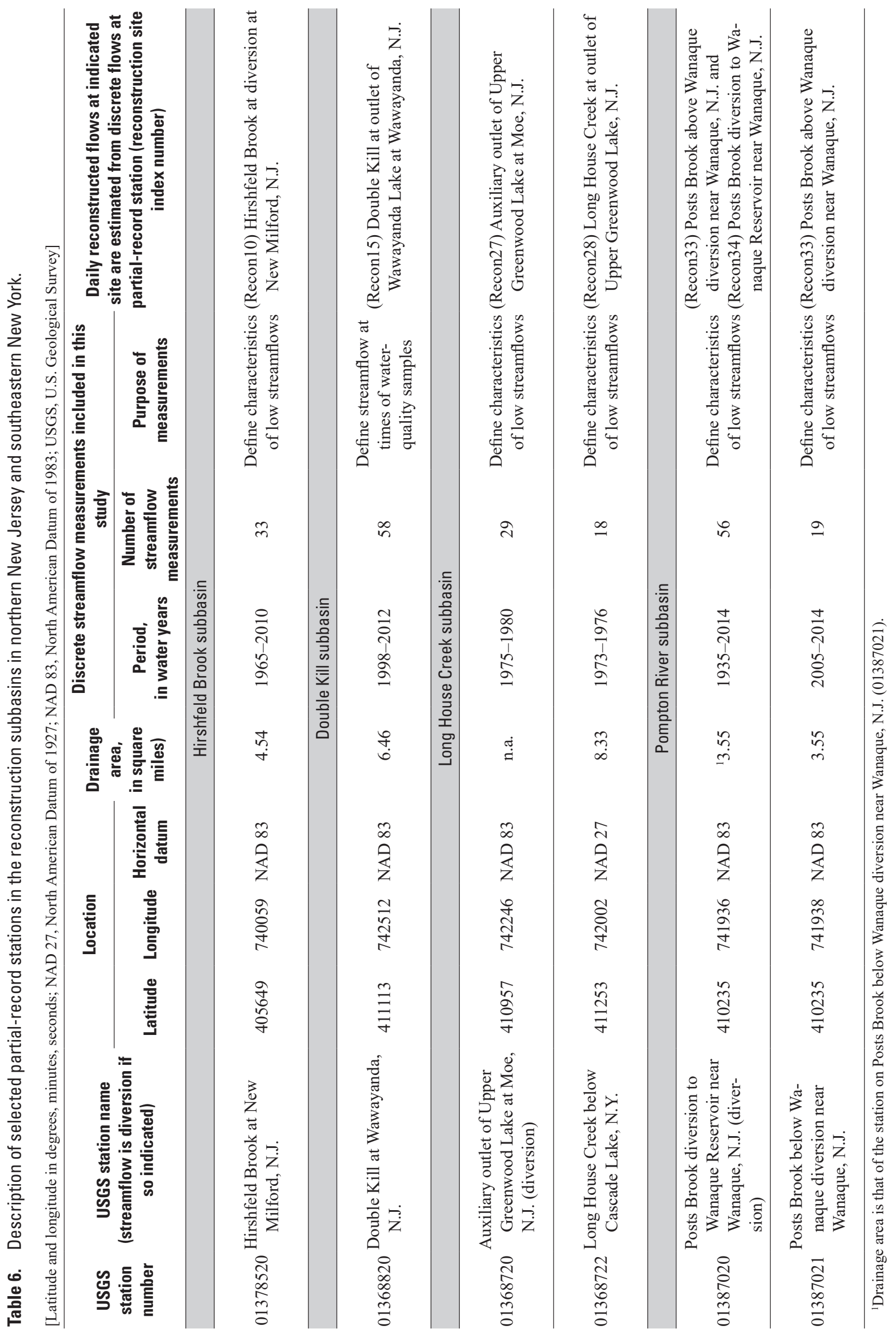


Table 7. Description of flow-reconstruction sites in the reconstruction subbasins in northern New Jersey and southeastern New York.

[Latitude and longitude in degrees, minutes, seconds; drainage area, in square miles; datum for latitude and longitude is North American Datum of 1983; N.J., New Jersey; N.Y., New York; USGS, U.S. Geological Survey; n.a., not applicable]

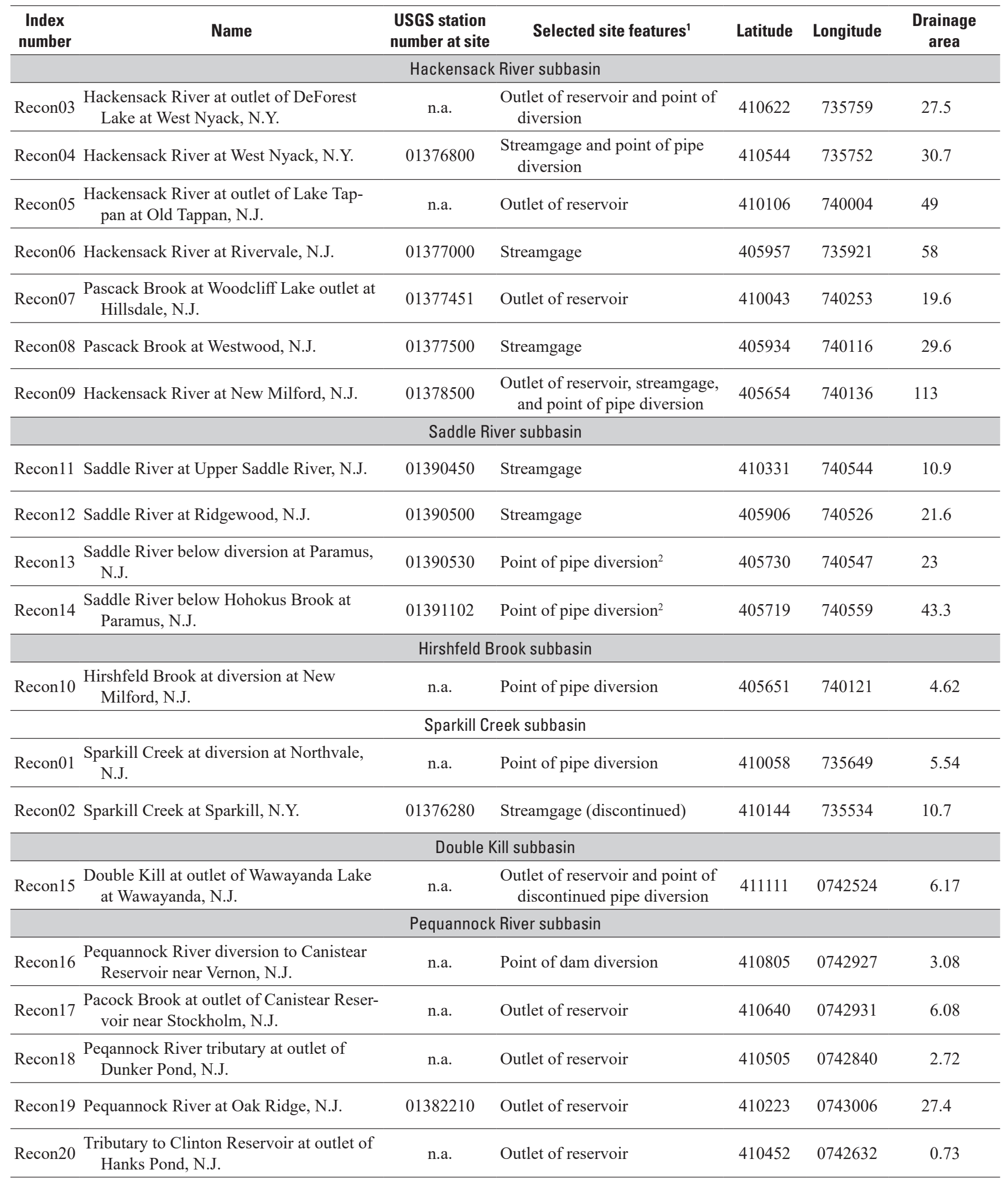


Table 7. Description of flow-reconstruction sites in the reconstruction subbasins in northern New Jersey and southeastern New York.-Continued

[Latitude and longitude in degrees, minutes, seconds; drainage area, in square miles; datum for latitude and longitude is North American Datum of 1983; N.J., New Jersey; N.Y., New York; USGS, U.S. Geological Survey; n.a., not applicable]

\begin{tabular}{|c|c|c|c|c|c|c|}
\hline $\begin{array}{l}\text { Index } \\
\text { number }\end{array}$ & Name & $\begin{array}{l}\text { USGS station } \\
\text { number at site }\end{array}$ & Selected site features ${ }^{1}$ & Latitude & Longitude & $\begin{array}{c}\text { Drainage } \\
\text { area }\end{array}$ \\
\hline \multicolumn{7}{|c|}{ Pequannock River subbasin-Continued } \\
\hline Recon 22 & $\begin{array}{l}\text { Clinton Brook at outlet of Clinton Reser- } \\
\text { voir near Newfoundland, N.J. }\end{array}$ & n.a. & Outlet of reservoir & 410428 & 0742651 & 10.5 \\
\hline Recon24 & $\begin{array}{l}\text { Mathews Brook diversion near Macopin, } \\
\text { N.J. }\end{array}$ & 01382430 & Point of dam diversion & 410255 & 0742420 & 1.95 \\
\hline Recon 25 & Macopin River at Echo Lake, N.J. & 01382410 & Outlet of reservoir & 410252 & 0742424 & 4.42 \\
\hline Recon27 & $\begin{array}{l}\text { Auxiliary outlet of Upper Greenwood } \\
\text { Lake at Moe, N.J. }\end{array}$ & 01368720 & Dam diversion & 410957 & 0742246 & n.a. \\
\hline Recon 28 & $\begin{array}{l}\text { Long House Creek at outlet of Upper } \\
\text { Greenwood Lake, N.J. }\end{array}$ & 01368721 & Outlet of reservoir & 411111 & 0742214 & 7.24 \\
\hline \multicolumn{7}{|c|}{ Wanaque River subbasin } \\
\hline Recon29 & $\begin{array}{l}\text { Wanaque River at outlet of Greenwood } \\
\text { Lake at Awosting, N.J. }\end{array}$ & 01383500 & $\begin{array}{l}\text { Streamgage and outlet of } \\
\text { reservoir }\end{array}$ & 410942 & 0742000 & 27.1 \\
\hline Recon30 & $\begin{array}{l}\text { Wanaque River at outlet of Monksville } \\
\text { Reservoir at Monks, N.J. }\end{array}$ & 01384000 & $\begin{array}{l}\text { Streamgage (discontinued) and } \\
\text { outlet of reservoir }\end{array}$ & 410721 & 0741749 & 40.4 \\
\hline Recon31 & $\begin{array}{l}\text { Wanaque River at outlet of Wanaque Res- } \\
\text { ervoir at Wanaque, N.J. }\end{array}$ & 01387000 & $\begin{array}{l}\text { Outlet of reservoir, } \\
\text { streamgage, and point of } \\
\text { pipe diversion }\end{array}$ & 410239 & 0741735 & 90.4 \\
\hline Recon34 & $\begin{array}{l}\text { Posts Brook diversion to Wanaque Reser- } \\
\text { voir near Wanaque, N.J. }\end{array}$ & 01387020 & Dam diversion & 410235 & 0741936 & n.a. \\
\hline Recon35 & Ramapo River at Pompton Lakes, N.J. & 01388000 & Streamgage & 405931 & 0741648 & 160 \\
\hline Recon36 & $\begin{array}{l}\text { Haycock Brook at outlet of Point View } \\
\text { Reservoir near Pompton Plains, N.J. }\end{array}$ & n.a. & $\begin{array}{l}\text { Outlet of reservoir and point of } \\
\text { pipe diversion }\end{array}$ & 405820 & 0741520 & 1.89 \\
\hline Recon37 & Pompton River at Pompton Plains, N.J. & 01388500 & Streamgage & 405811 & 0741655 & 355 \\
\hline \multicolumn{7}{|c|}{ Musconetcong River subbasin } \\
\hline Recon38 & $\begin{array}{l}\text { Musconetcong River at outlet of Lake } \\
\text { Hopatcong, N.J }\end{array}$ & 01455500 & $\begin{array}{l}\text { Outlet of reservoir and site of } \\
\text { streamgage, }\end{array}$ & 405502 & 0743956 & 25.3 \\
\hline
\end{tabular}


Table 7. Description of flow-reconstruction sites in the reconstruction subbasins in northern New Jersey and southeastern New York.-Continued

[Latitude and longitude in degrees, minutes, seconds; drainage area, in square miles; datum for latitude and longitude is North American Datum of 1983; N.J., New Jersey; N.Y., New York; USGS, U.S. Geological Survey; n.a., not applicable]

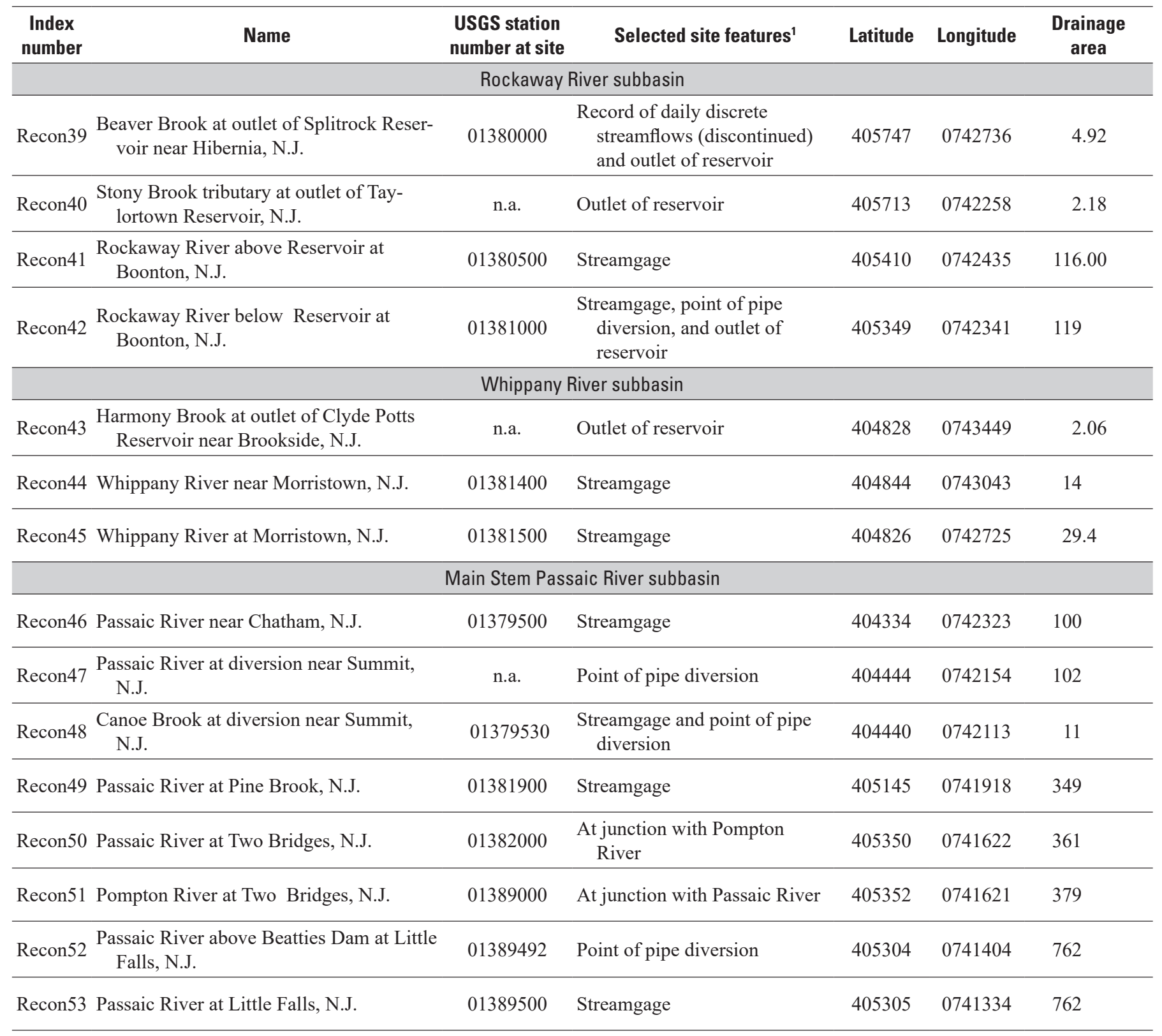

\footnotetext{
${ }^{1}$ For this report, all diversions from reservoirs are considered to be located at the reservoir outlet.

${ }^{2}$ The surface-water diversion at Paramus withdraws water from the Saddle River reach downstream to the junction with Hohokus Brook.
} 


\section{Methods}

Methods are presented in three sections: "Assembling Information Needed to Determine Monthly Reconstructed Flows," "Determination of Monthly Reconstructed Flows," and "Determination of Daily Reconstructed Flows from Monthly Reconstructed Flows." In these sections, the methods are presented in general terms. More detailed information about the application of these methods specific to each flowreconstruction site is provided in appendixes 1-4.

\section{Assembling Information Needed to Determine Monthly Reconstructed Flows}

Assembled information consisted of observed streamflows, rates of transfer for selected diversions, and changes in reservoir storage. Measured and estimated values were included.

\section{Monthly Observed Streamflow at Streamgages}

Published daily observed streamflows at selected streamgages (table 5) were retrieved from the USGS National Water Information System (NWIS) website at https://waterdata.usgs.gov/usa/nwis/sw. Monthly observed streamflows were calculated from daily values.

Some published streamflows reported by the USGS were not used in this report. The streamflows at Pompton River at Pompton Plains, N.J. (01388500), for water years 1940-2010 were not used because of uncertainties in the reported medium and high flows; this streamgage is in the Pompton River subbasin. The streamflows at Passaic River at Pine Brook, N.J. (01381900), for water years 1979-2005 were not used because of difficulties in incorporating variable backwater into streamflows during this period; this streamgage is in the Main Stem Passaic River subbasin.

Selected monthly observed streamflows at four streamgages in the Saddle River, Pompton River, and Main Stem Passaic River subbasins (table 5) were estimated from published monthly observed streamflows at other streamgages in order to complete the periods of record for the study period 1922-2010. Specific details of the estimation calculations are given in appendix 1. In this report, the term "observed" is used to indicate true streamflow conditions, which include water withdrawals and effects of reservoirs, and not necessarily values measured by gaging equipment. Therefore, "estimated observed" data are those that are estimated but which include effects of water use. The goal was to fill in as much record as possible with simple drainage area adjustments of gaged streamflow, rather than estimating after reconstruction.

Monthly observed flows at one streamgage were calculated from unpublished USGS records of daily observed streamflows (table 5) obtained from the New Jersey Water
Science Center of the USGS. Records for Canoe Brook near Summit, N.J. (01379530), for water years 1966-2001 are incomplete and unpublished; this streamgage is in the Main Stem Passaic River subbasin. Published streamflow records began in 2002. Prior to that, computing streamflow proved difficult because of backwater conditions from the Passaic River and surface-water withdrawals from the streamgage pool. The backwater effects would result in negative and zero flows for short periods of time. For periods of non-backwater, the record is considered to be valid. For the purposes of this investigation, the unpublished record is considered to be adequate. The use of the Canoe Brook data does not imply approval by USGS standards.

Estimates of observed streamflows at Beaver Brook at outlet of Splitrock Reservoir, N.J. (01380000), were determined from once-daily stage measurements provided to the USGS during water years 1976-89 by Jersey City and a stage-discharge rating developed by USGS; methods used to calculate monthly streamflows in Beaver Brook are presented in appendix 2. The Beaver Brook streamgage is in the Rockaway River subbasin. Records were not published or otherwise approved by USGS because (1) only once-daily readings would not necessarily indicate a mean reading for the day, and (2) those readings were not collected by USGS. Despite these substandard conditions for flow determination, this record is considered to be adequate for the purposes of this analysis and provides the best flow data available at this site without the use of complex empirical or mathematical models for estimation. The use of the Beaver Brook records in this investigation does not imply approval by USGS standards.

\section{Daily and Monthly Observed Streamflows at Partial-Record Stations}

Available discrete measurements of streamflow at six partial-record stations (table 6) were retrieved from the NWIS website. Measurements at four stations were retrieved for water years 1922-2010; measurements at one station were retrieved for water years 1922-2012 and, at another station, for water years 1922-2014.

Daily and monthly observed streamflows at each partial-record station were estimated from MOVE1 relations between discrete streamflows at the partial-record station and daily observed streamflows at each index gage (appendix 3). Monthly observed flows at the partial-record stations were then calculated from daily flows.

\section{Rates of Monthly Transfer at Surface-Water Diversions}

Monthly rates of transfer for the selected surface-water diversions (table 4) were either reported or estimated. Sources of reported rates of transfer in pipe diversions are listed in 
table 8 ; most reported values were from the compilation by the New Jersey Geological and Water Survey (2013). The North Jersey District Water supply commission uses three separate pipe diversions (Div13, Div16, and Div24) to transfer water to the Oradell Reservoir. Although the total water transferred to Oradell Reservoir was available from the compilation, the rates for each individual diversion were not. Rates of transfer for the three pipe diversions to Oradell Reservoir (Div13, Div16, and Div24) were therefore estimated, as described in appendix 4. Also missing from the compilation were rates of transfer for two New Jersey American Water Company diversions at Summit (Div21 and Div22) prior to 1978. Data for the period 1965-73 were provided by NJDEP and are available in the data release associated with this report (Hickman, 2018).

Monthly rates of transfer for all dam diversions were estimated. Monthly rates of transfer for some diversions were estimated from monthly observed streamflows estimated for partial-record stations (table 6). Monthly rates of transfer for the remaining dam diversions were estimated from drainagearea adjustment of reconstructed flows at selected sites.

\section{Changes in Reservoir Storage}

Changes in reservoir storage were determined from reported end-of-month storage at selected reservoirs (table 3). Values of end-of-month storage for months prior to the construction of each reservoir were set to zero.

\section{Determination of Monthly Reconstructed Flows}

Monthly reconstructed flows were determined for sites at which a record of monthly streamflow was either measured for a streamgage at the site (observed streamflow) or estimated from the record of streamflow for a nearby streamgage (estimated observed streamflow). In the following discussions, "observed flows" include those from a streamgage and those that were estimated. These methods were not applied to any site at which the monthly reconstructed flows were estimated from discrete streamflow measurements at partial-record stations.

In general, three methods were used to determine monthly reconstructed flows at a site. First, monthly reconstructed flows were calculated by adjusting monthly observed streamflow for changes in reservoir storage and diversions. Second, monthly reconstructed flows not calculated because of insufficient data were estimated from relations between (1) selected calculated monthly reconstructed flows and (2) monthly flows at each index gage. Third, at some sites, monthly reconstructed flows were determined from corresponding values at other sites, by summing upstream reconstructed flows and (or) using a drainage area adjustment on appropriate nearby reconstructed flows.

\section{Calculation and Estimation of Monthly Reconstructed Flows at Sites with Monthly Streamflow}

For each reconstruction site with a record of monthly streamflow, a monthly streamflow adjustment was determined for each month by summing (1) the rate of diversion out of the site drainage area minus the rate of diversion into it and (2) the change in monthly reservoir storage within the drainage area (eq. 1). The monthly reconstructed streamflow was calculated by summing monthly observed streamflow and streamflow adjustment (eq. 2).

$$
\begin{gathered}
\text { mReconXXadj }=\left(\text { Div }_{\text {out }}-\text { Div }_{\text {in }}\right)+\text { DelStorage } \\
\text { ReconXX }=m A A A A A A A A+m \text { ReconXXadj }
\end{gathered}
$$

where

mReconXXadj is monthly streamflow adjustment at selected reconstruction site, in cubic feet per second;

Div $v_{\text {out }}$ is monthly surface-water diversions out of drainage area of the streamgage, in cubic feet per second;

Div $v_{\text {in }} \quad$ is monthly surface-water diversions into drainage area of the streamgage, in cubic feet per second;

DelStorage is sum of changes in monthly storage of selected reservoirs in the drainage area of the streamgage, in cubic feet per second;

$m A A A A A A A$ is monthly observed streamflow at streamgage with station number $A A A A A A A A$, in cubic feet per second; and

ReconXX is calculated monthly reconstructed streamflow at reconstruction site, $X X$, in cubic feet per second.

Monthly reconstructed flows could not be calculated for each site for all months of the period of study, usually because of missing records of monthly observed streamflow. Some records of reservoir storage and pipe diversions also were incomplete.

For a few sites, some values of calculated monthly reconstructed flows were determined by setting some missing values of diversion or change in reservoir storage to zero. This was done only if the missing term appeared to be a small part of the reconstructed flow. Instances when this was done are mentioned in the section "Application of Methods to FlowReconstruction Sites in Each Subbasin."

Missing values of monthly reconstructed flows at a selected site were estimated from relations between selected 
calculated monthly reconstructed flows and monthly observed flows at each index gage. The form of each relation is given in equation 3 .

$$
m \text { ReconXX_calc }=(\text { mIndex } \times \text { slope })+\text { intercept }
$$

where,

$$
\begin{aligned}
& \text { mReconXX_calc is calculated monthly reconstructed } \text { streamflow, in cubic feet per second; } \\
& \text { mIndex is monthly observed streamflow at index } \text { gage, in cubic feet per second; } \\
& \text { slope is equation slope, unitless; and } \text { intercept is equation intercept, in cubic feet per } \\
& \text { second. }
\end{aligned}
$$

Periods of missing values of monthly reconstructed flows for each site were identified (table 9). As many as three periods of missing values were designated for each site.

For each period of missing monthly reconstructed flows, a period of selected calculated monthly reconstructed flows was identified (table 9). Relations to estimate the missing values were developed between these selected calculated values and monthly observed streamflows for each index gage. The period of calculated values was selected to be as close in time as possible to the period of missing values and to consist of up to 240 months.

It was found that a single equation did not sufficiently represent the relation between each of the flow-reconstruction sites and the index gage for the full range of monthly flows. An obvious difference in the relation was observed when flows at the index gage were less than 50 cubic feet per second $\left(\mathrm{ft}^{3} / \mathrm{s}\right)$. The relation was found to be further improved by separating the monthly data into classes on the basis of the ratio of maximum daily mean flow to daily mean flow on the first day of the month. Each month of the period of study was therefore divided into four hydrologic classes on the basis of the record of daily observed streamflow at the index gage Pequest River at Pequest, N.J. (01445500). For most sites, missing monthly reconstructed flows in each period were then estimated from four separate relations between selected calculated monthly reconstructed flows and monthly observed streamflows at each index gage (table 9), based on the defined class. Each class was defined by (1) the daily streamflow on the first day of the month and (2) the ratio of the maximum daily streamflow to the streamflow on the first day.

- Class 1:

- Streamflow on first day of month is less than or equal to $50 \mathrm{ft}^{3} / \mathrm{s}$.

- Ratio of maximum daily streamflow in the month to streamflow on first day is less than or equal to 2 .

- Class 2:

- Streamflow on first day of month is less than or equal to $50 \mathrm{ft}^{3} / \mathrm{s}$.
- Ratio of maximum daily streamflow in the month to streamflow on first day is greater than 2 .

- Class 3:

- Streamflow on first day of month is greater than 50 $\mathrm{ft}^{3} / \mathrm{s}$.

- Ratio of maximum daily flow in the month to streamflow on first day is less than or equal to 1 .

- Class 4:

- Streamflow on first day of the month is greater than $50 \mathrm{ft}^{3} / \mathrm{s}$.

- Ratio of maximum daily flow in the month to streamflow on first day is greater than 1 .

For a few periods of missing values at selected sites, there were far fewer than 240 months of calculated total reconstructed flows to create the relations. For these, only one relation was developed between the calculated values and monthly observed streamflows at each index gage.

For the relations of the monthly reconstructed flow sites versus index gages for each of the defined classes, values of slope and intercept in each equation were determined by use of the Maintenance of Variance Extension Type 1 (Hirsch, 1982). This linear regression method, known as MOVE1, is described in appendix 5. Values of slope and intercept for each equation are presented in the data release (Hickman, 2018).

Estimated values of monthly reconstructed flows were those determined from the MOVE1 equations derived using monthly observed flows in the Paulins Kill at Blairstown, N.J. (01443500). Missing values during water year 1977 were filled in with the corresponding values estimated from the MOVE1 equations using observed monthly streamflow in the Pequest River at Pequest, N.J. (01445500).

\section{Estimation of Monthly Reconstructed Flows from Corresponding Values at Other Sites}

At a few sites, monthly reconstructed flows were determined from monthly reconstructed flows at other sites using one of two methods. For the first method, monthly reconstructed flows at one site were estimated from a drainage-area adjustment of corresponding flows at a second site.

The second method was to determine monthly reconstructed flows at selected sites by calculating and estimating "sectional" monthly reconstructed flows occurring between sites of known flow. These sectional flows can be thought of as local inflow in the intervening area between sites in a section of the subbasin. These sectional flows were needed specifically for the lower part of the Main Stem Passaic River subbasin, in the areas downstream from Pompton Plains and Chatham to Little Falls, N.J. (fig. 9). Here, the local contributing flow per square mile is different than upstream in the basin because it can be considerably affected by seasonal evapotranspiration 
rates from wetlands and effects of variable backwater as the Pompton River joins the Passaic River at Two Bridges, N.J. Sectional flows also were used for estimates in the relatively isolated basin of Haycock Brook where the flow per square mile between Mahwah and Pompton Lakes was utilized. Sectional monthly reconstructed flows were calculated for months with sufficient data using equation 4.

$$
m \operatorname{Recon} X X \sec =m \operatorname{Recon} X X-\Sigma_{\text {upstream_gages }}\left(m_{\operatorname{Recon}} n_{\text {gage }}\right)
$$

where

$m$ ReconXXsec is sectional monthly reconstructed flows at site $X X$, in cubic feet per second;

$m$ Recon $X X$ is monthly reconstructed flows at site $X X$, in cubic feet per second; and

mRecon $_{\text {gage }}$ is monthly reconstructed flows at each selected streamgage upstream from site $X X$, in cubic feet per second.

Sectional monthly reconstructed flows were computed first from available observed flows. For periods without observed flows, sectional monthly reconstructed flows also were estimated as previously described using a MOVE1 regression with index gages. Periods of missing sectional reconstructed flows are given in table 9.

Monthly reconstructed flows at selected sites were determined by (1) calculating and estimating monthly reconstructed flows at the upstream streamgages, (2) calculating and estimating sectional monthly reconstructed flows to the site, and (3) summing the two sets of values. The general equation for these sites is equation 5 .

$$
\begin{aligned}
& m \operatorname{Recon} X Y=\left(\frac{D x y}{D x x}\right) \times m \operatorname{Recon} X X \text { sec } \\
& +\sum_{\text {upstream_gages }}\left(\text { mRecon }_{\text {gage }}\right)
\end{aligned}
$$

where

$$
\begin{aligned}
& \text { mRecon } X Y \text { is monthly reconstructed flows at site } X Y \text {, in } \\
& \text { Dxy is drainage area of sectional monthly } \\
& \text { reconstructed flows of site } X Y \text {, in square } \\
& \text { miles; } \\
& D x x \quad \text { is drainage area of sectional monthly } \\
& \text { reconstructed flows site } X X \text {, in square } \\
& \text { miles; }
\end{aligned}
$$

\section{Determination of Daily Reconstructed Flows from Monthly Reconstructed Flows}

Daily reconstructed streamflows were determined by disaggregating monthly reconstructed streamflows on the basis of observed streamflow at selected "disaggregation" streamgages (table 10, fig. 3). A primary and a secondary disaggregation streamgage are shown in table 10 for most sites. In the event that the primary disaggregation streamgage did not have sufficient data for the entire study period, the secondary site was used to fill in the remaining period of study. This method was not applied to the five sites at which reconstructed flows were determined from discrete streamflow measurements at partialrecord stations.

To disaggregate monthly reconstructed flows, the daily observed streamflow at each disaggregation streamgage was converted from cubic feet per second to percent of total monthly flow for each month of the period of study using equation 6 . The total flow is the monthly flow times the days in the month.

$$
q_{-} \operatorname{disagg}_{p c t}=100 \times\left(\frac{q_{-} \operatorname{disagg}_{c f s}}{m_{-} \operatorname{disagg}_{c f s} \times \operatorname{days}}\right)
$$

where

$$
\begin{aligned}
& \text { q_disagg }{ }_{\text {pct }} \text { is daily observed streamflow at } \\
& \text { disaggregation streamgage, in percent of } \\
& \text { total monthly streamflow; } \\
& q_{\text {disagg }} \text { iss daily observed streamflow at } \\
& \text { disaggregation streamgage, in cubic feet } \\
& \text { per second; } \\
& m \_ \text {disagg }{ }_{c f s} \text { is monthly mean observed streamflow at } \\
& \text { disaggregation streamgage, in cubic feet } \\
& \text { per second; and } \\
& \text { day } \quad s \text { is number of days in the month. }
\end{aligned}
$$

Then, daily reconstructed streamflows at the reconstruction site were estimated from the daily observed streamflows, in percent of total monthly streamflow, at a disaggregation streamgage using equation 7.

$$
q \operatorname{Re} \operatorname{con} X X_{c f s}=\frac{m \operatorname{Recon} X X_{c f s} \times q \text { disagg }_{p c t} \times \text { days }}{100}
$$

where

$$
\begin{aligned}
& q_{-} \operatorname{Recon} X X_{c f s} \text { is daily reconstructed flow at reconstruction } \\
& \text { site } \mathrm{XX} \text {, in cubic feet per second; } \\
& m \_ \text {Recon } X X_{c f s} \text { is monthly reconstructed flow at } \\
& \text { reconstruction site } \mathrm{XX} \text {, in cubic feet per } \\
& \text { second; } \\
& \text { q_disagg } \text { pct }_{\text {is daily observed streamflow at }} \\
& \text { disaggregation streamgage, in percent of } \\
& \text { total monthly streamflow; and } \\
& \text { days is number of days in the month. }
\end{aligned}
$$




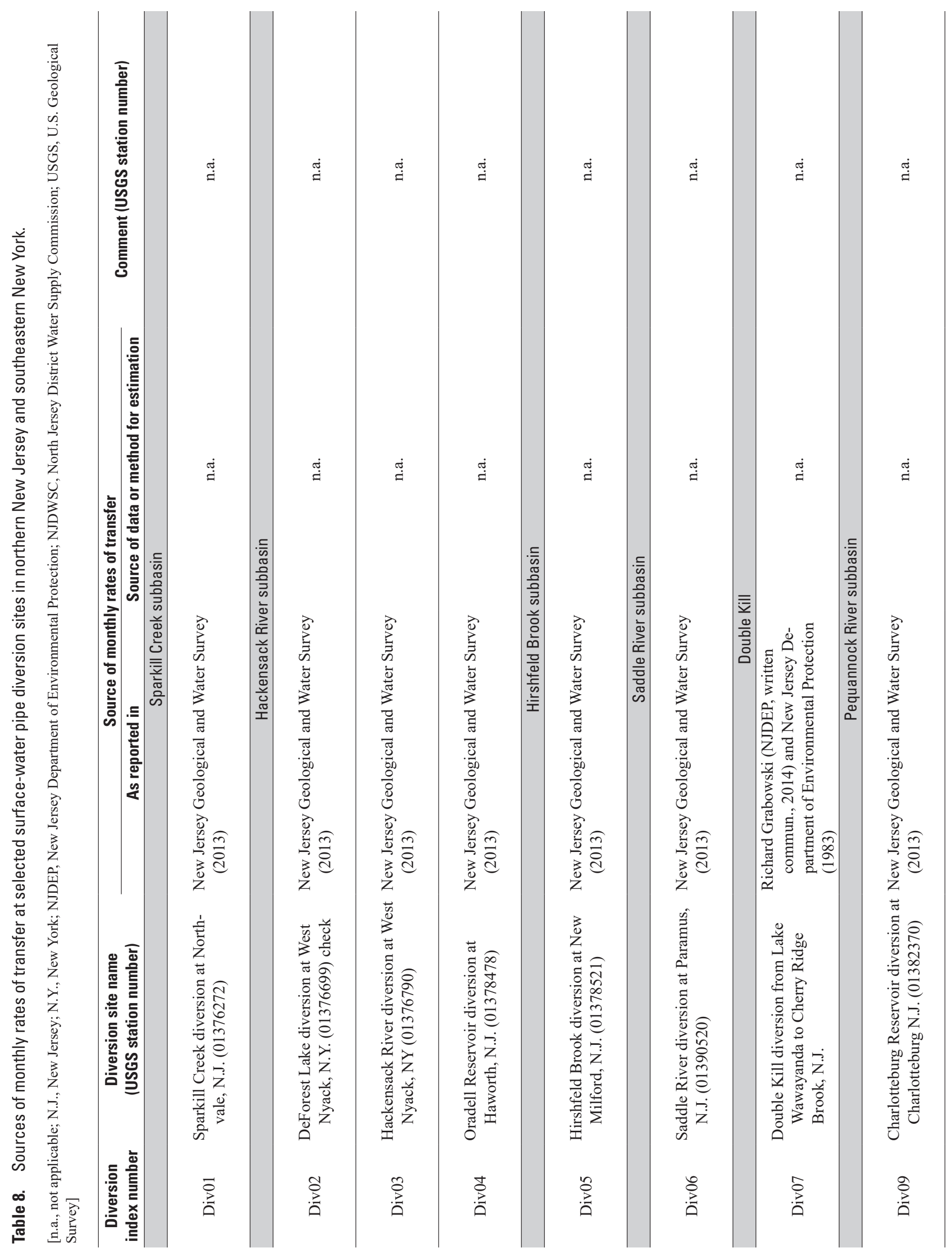




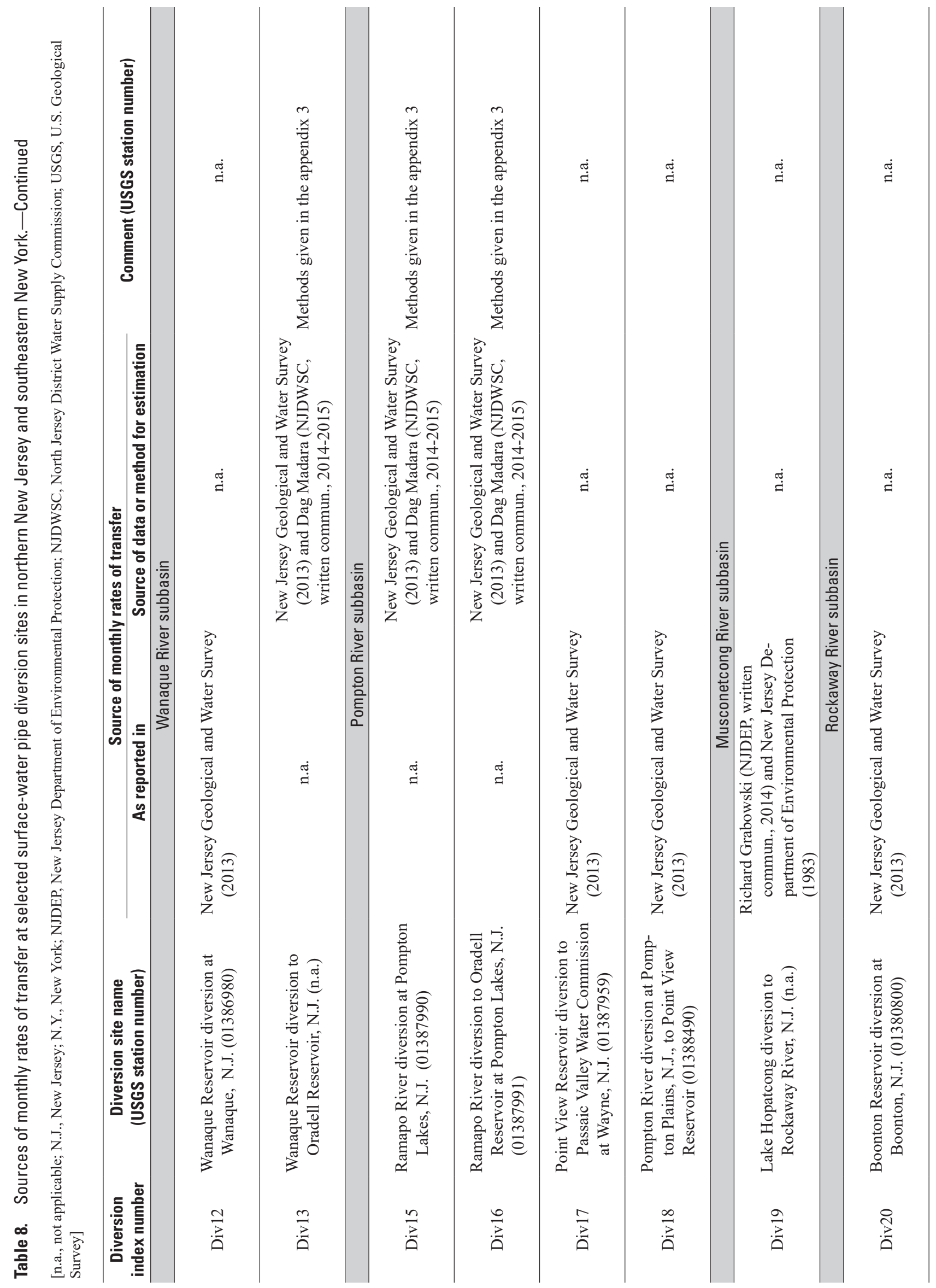




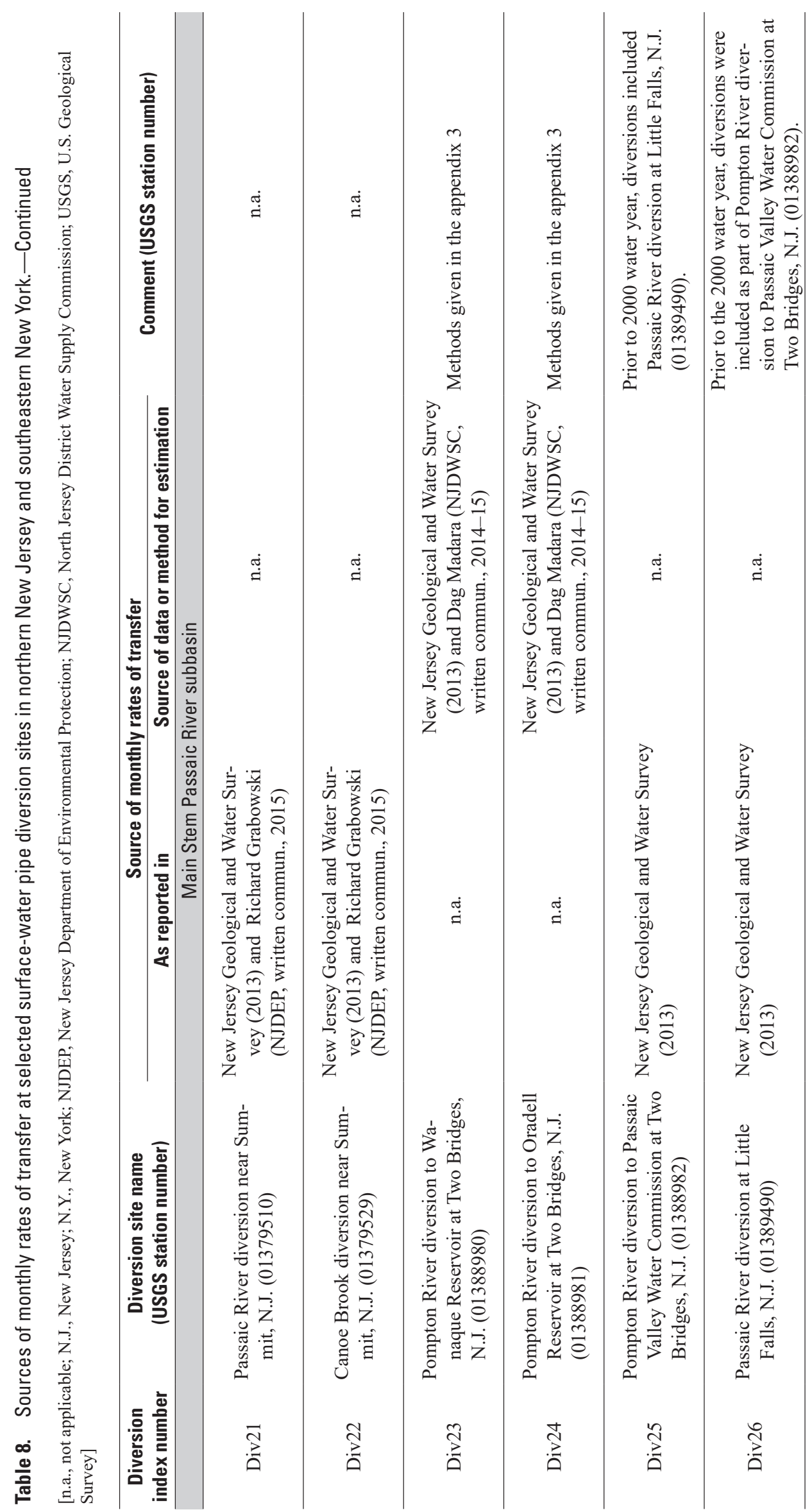


Table 9. Periods of calculated reconstructed flows used to develop relations at selected flow-reconstruction sites, by subbasin, in northern New Jersey and southeastern New York and periods over which monthly reconstructed flows were estimated with these relations.

[N.Y., New York; N.J., New Jersey; T, total monthly reconstructed flows; Sec, sectional monthly reconstructed flows]

\begin{tabular}{|c|c|c|c|c|}
\hline \multirow[t]{2}{*}{$\begin{array}{l}\text { Type of monthly } \\
\text { reconstructed flows } \\
\text { determined from } \\
\text { MOVE1 relations }\end{array}$} & \multicolumn{2}{|c|}{$\begin{array}{c}\text { Period of calculated } \\
\text { monthly reconstructed } \\
\text { flows used to determine } \\
\text { MOVE1 relations, } \\
\text { in water years }\end{array}$} & \multicolumn{2}{|c|}{$\begin{array}{l}\text { Period of estimates of } \\
\text { monthly reconstructed } \\
\text { flows used to fill in missing } \\
\text { calculated values, } \\
\text { in water years }{ }^{1}\end{array}$} \\
\hline & First & Last & First & Last \\
\hline \multicolumn{5}{|c|}{ (Recon02) Sparkill Creek at Sparkill, N.Y. } \\
\hline $\mathrm{T}$ & 1960 & 1978 & 1922 & 2010 \\
\hline \multicolumn{5}{|c|}{ (Recon04) Hackensack River at West Nyack, N.Y. } \\
\hline $\mathrm{T}$ & 1959 & 1979 & 1922 & 1959 \\
\hline \multicolumn{5}{|c|}{ (Recon06) Hackensack River at Rivervale, N.J. } \\
\hline $\mathrm{T}$ & 1942 & 1961 & 1922 & 1941 \\
\hline \multicolumn{5}{|c|}{ (Recon08) Pascack Brook at Westwood, N.J. } \\
\hline $\mathrm{T}$ & 1935 & 1954 & 1922 & 1934 \\
\hline \multicolumn{5}{|c|}{ (Recon11) Saddle River at Upper Saddle River, N.J. } \\
\hline $\mathrm{T}$ & 1955 & 1974 & 1922 & 1988 \\
\hline $\mathrm{T}$ & 1964 & 1986 & 1975 & 1977 \\
\hline $\mathrm{T}$ & 1978 & 1999 & 1986 & 1988 \\
\hline \multicolumn{5}{|c|}{ (Recon12) Saddle River at Ridgewood, N.J. } \\
\hline $\mathrm{T}$ & 1955 & 1974 & 1922 & 1954 \\
\hline $\mathrm{T}$ & 1964 & 1986 & 1975 & 1977 \\
\hline $\mathrm{T}$ & 1978 & 1999 & 1986 & 1988 \\
\hline \multicolumn{5}{|c|}{ (Recon14) Saddle River below Hohokus Brook at Paramus, N.J. } \\
\hline $\mathrm{T}$ & 1924 & 1943 & 1922 & 1923 \\
\hline \multicolumn{5}{|c|}{ (Recon26) Pequannock River at Macopin Intake Dam, N.J. } \\
\hline $\mathrm{T}$ & 1923 & 1942 & 1922 & 1922 \\
\hline $\mathrm{T}$ & 1980 & 2002 & 1990 & 1992 \\
\hline \multicolumn{5}{|c|}{ (Recon29) Wanaque River at outlet of Greenwood Lake at Awosting, N.J. } \\
\hline $\mathrm{T}$ & 1984 & 2004 & 1994 & 1994 \\
\hline \multicolumn{5}{|c|}{ (Recon30) Wanaque River at outlet of Monksville Reservoir at Monks, N.J. } \\
\hline $\mathrm{T}$ & 1935 & 1954 & 1922 & 1934 \\
\hline $\mathrm{T}$ & 1965 & 1985 & 1985 & 2010 \\
\hline \multicolumn{5}{|c|}{ (Recon31) Wanaque River at outlet of Wanaque Reservoir at Wanaque, N.J. } \\
\hline $\mathrm{T}$ & 1984 & 2004 & 1994 & 1994 \\
\hline \multicolumn{5}{|c|}{ (Recon35) Ramapo River at Pompton Lakes, N.J. } \\
\hline Sec & 1923 & 1942 & 1922 & 1923 \\
\hline \multicolumn{5}{|c|}{ (Recon37) Pompton River at Pompton Plains, N.J. } \\
\hline $\mathrm{T}$ & 1923 & 1942 & 1922 & 1923 \\
\hline $\mathrm{T}$ & 1981 & 2003 & 1990 & 1994 \\
\hline \multicolumn{5}{|c|}{ (Recon38) Musconetcong River at outlet of Lake Hopatcong, N.J. } \\
\hline $\mathrm{T}$ & 1961 & 1975 & 1922 & 1960 \\
\hline $\mathrm{T}$ & 1964 & 2010 & 1976 & 2002 \\
\hline \multicolumn{5}{|c|}{ (Recon39) Beaver Brook at outlet of Splitrock Reservoir near Hibernia, N.J. } \\
\hline $\mathrm{T}$ & 1976 & 1988 & 1922 & 2010 \\
\hline \multicolumn{5}{|c|}{ (Recon41) Rockaway River above Reservoir at Boonton, N.J. } \\
\hline $\mathrm{T}$ & 1938 & 1957 & 1922 & 1937 \\
\hline \multicolumn{5}{|c|}{ (Recon44) Whippany River near Morristown, N.J. } \\
\hline $\mathrm{T}$ & 1995 & 2010 & 1922 & 1995 \\
\hline \multicolumn{5}{|c|}{ (Recon48) Canoe Brook at diversion near Summit, N.J. } \\
\hline $\mathrm{T}$ & 1966 & 2000 & 1922 & 1990 \\
\hline & (Reco & ssaic Riv & N.J. & \\
\hline $\mathrm{T}$ & 2006 & 2010 & 1922 & 2005 \\
\hline Sec & 2006 & 2010 & 1922 & 2005 \\
\hline & (Recc & ssaic Riv & V.J. & \\
\hline $\mathrm{T}$ & 1985 & 2004 & 1994 & 1994 \\
\hline Sec & 2006 & 2010 & 1922 & 2005 \\
\hline
\end{tabular}


Table 10. Disaggregation streamgages used to determine daily reconstructed flows from monthly reconstructed flows at flowreconstruction sites in northern New Jersey and southeastern New York.

[n.a., not applicable; N.J., New Jersey; N.Y., New York; USGS, U.S. Geological Survey]

\begin{tabular}{|c|c|c|c|}
\hline \multicolumn{2}{|r|}{ Flow-reconstruction site } & \multicolumn{2}{|c|}{ Disaggregation streamgage (USGS station number) } \\
\hline Index number & Name (USGS station number) & Primary & Secondary \\
\hline \multicolumn{4}{|c|}{ Sparkill Creek } \\
\hline Recon02 & Sparkill Creek at Sparkill, N.Y. (01376280) & Saddle River at Lodi (01391500) & $\begin{array}{l}\text { Ramapo River at Pompton Lakes } \\
(01388000)\end{array}$ \\
\hline Recon03 & $\begin{array}{l}\text { Hackensack River at outlet of DeForest } \\
\text { Lake at West Nyack, N.Y. (n.a.) }\end{array}$ & Saddle River at Lodi (01391500) & $\begin{array}{l}\text { Ramapo River at Pompton Lakes } \\
(01388000)\end{array}$ \\
\hline Recon04 & $\begin{array}{l}\text { Hackensack River at West Nyack, N.Y. } \\
\quad(01376800)\end{array}$ & Saddle River at Lodi (01391500) & $\begin{array}{l}\text { Ramapo River at Pompton Lakes } \\
(01388000)\end{array}$ \\
\hline Recon05 & $\begin{array}{l}\text { Hackensack River at outlet of Lake Tappan } \\
\text { at Old Tappan, N.J. (n.a.) }\end{array}$ & Saddle River at Lodi (01391500) & $\begin{array}{l}\text { Ramapo River at Pompton Lakes } \\
(01388000)\end{array}$ \\
\hline Recon07 & $\begin{array}{l}\text { Pascack Brook at Woodcliff Lake outlet at } \\
\text { Hillsdale, N.J. (01377451) }\end{array}$ & Saddle River at Lodi (01391500) & $\begin{array}{l}\text { Ramapo River at Pompton Lakes } \\
(01388000)\end{array}$ \\
\hline Recon08 & $\begin{array}{l}\text { Pascack Brook at Westwood, N.J. } \\
(01377500)\end{array}$ & Saddle River at Lodi (01391500) & $\begin{array}{l}\text { Ramapo River at Pompton Lakes } \\
(01388000)\end{array}$ \\
\hline Recon09 & $\begin{array}{l}\text { Hackensack River at New Milford, N.J. } \\
\quad(01378500)\end{array}$ & Saddle River at Lodi (01391500) & $\begin{array}{l}\text { Ramapo River at Pompton Lakes } \\
(01388000)\end{array}$ \\
\hline \multicolumn{4}{|c|}{ Hirshfeld Brook } \\
\hline Recon 10 & $\begin{array}{l}\text { Hirshfeld Brook at diversion at New Mil- } \\
\text { ford, N.J. (n.a.) }\end{array}$ & n.a. & n.a. \\
\hline \multicolumn{4}{|c|}{ Saddle River } \\
\hline Recon14 & $\begin{array}{l}\text { Saddle River below Hohokus Brook at } \\
\text { Paramus, N.J. (01391102) }\end{array}$ & Saddle River at Lodi (01391500) & $\begin{array}{l}\text { Ramapo River at Pompton Lakes } \\
(01388000)\end{array}$ \\
\hline \multicolumn{4}{|c|}{ Double Kill } \\
\hline Recon 15 & $\begin{array}{l}\text { Double Kill at outlet of Wawayanda Lake at } \\
\text { Wawayanda, N.J. (n.a.) }\end{array}$ & n.a. & n.a. \\
\hline \multicolumn{4}{|c|}{ Pequannock River } \\
\hline Recon16 & $\begin{array}{l}\text { Pequannock River diversion to Canistear } \\
\text { Reservoir near Vernon, N.J. (n.a.) }\end{array}$ & $\begin{array}{l}\text { Rockaway River above Reservoir at } \\
\text { Boonton, N.J. (01380500) }\end{array}$ & $\begin{array}{l}\text { Ramapo River at Pompton Lakes, N.J. } \\
(01388000)\end{array}$ \\
\hline Recon 17 & $\begin{array}{l}\text { Pacock Brook at outlet of Canistear Reser- } \\
\text { voir near Stockholm, N.J. (n.a.) }\end{array}$ & $\begin{array}{l}\text { Rockaway River above Reservoir at } \\
\text { Boonton, N.J. (01380500) }\end{array}$ & $\begin{array}{l}\text { Ramapo River at Pompton Lakes, N.J. } \\
(01388000)\end{array}$ \\
\hline Recon 18 & $\begin{array}{l}\text { Peqannock River tributary at outlet of } \\
\text { Dunker Pond, N.J. (n.a.) }\end{array}$ & $\begin{array}{l}\text { Rockaway River above Reservoir at } \\
\text { Boonton, N.J. (01380500) }\end{array}$ & $\begin{array}{l}\text { Ramapo River at Pompton Lakes, N.J. } \\
(01388000)\end{array}$ \\
\hline Recon19 & $\begin{array}{l}\text { Pequannock River at Oak Ridge, N.J. } \\
(01382210)\end{array}$ & $\begin{array}{l}\text { Rockaway River above Reservoir at } \\
\text { Boonton, N.J. (01380500) }\end{array}$ & $\begin{array}{l}\text { Ramapo River at Pompton Lakes, N.J. } \\
(01388000)\end{array}$ \\
\hline
\end{tabular}


Table 10. Disaggregation streamgages used to determine daily reconstructed flows from monthly reconstructed flows at flowreconstruction sites in northern New Jersey and southeastern New York.-Continued

[n.a., not applicable; N.J., New Jersey; N.Y., New York; USGS, U.S. Geological Survey]

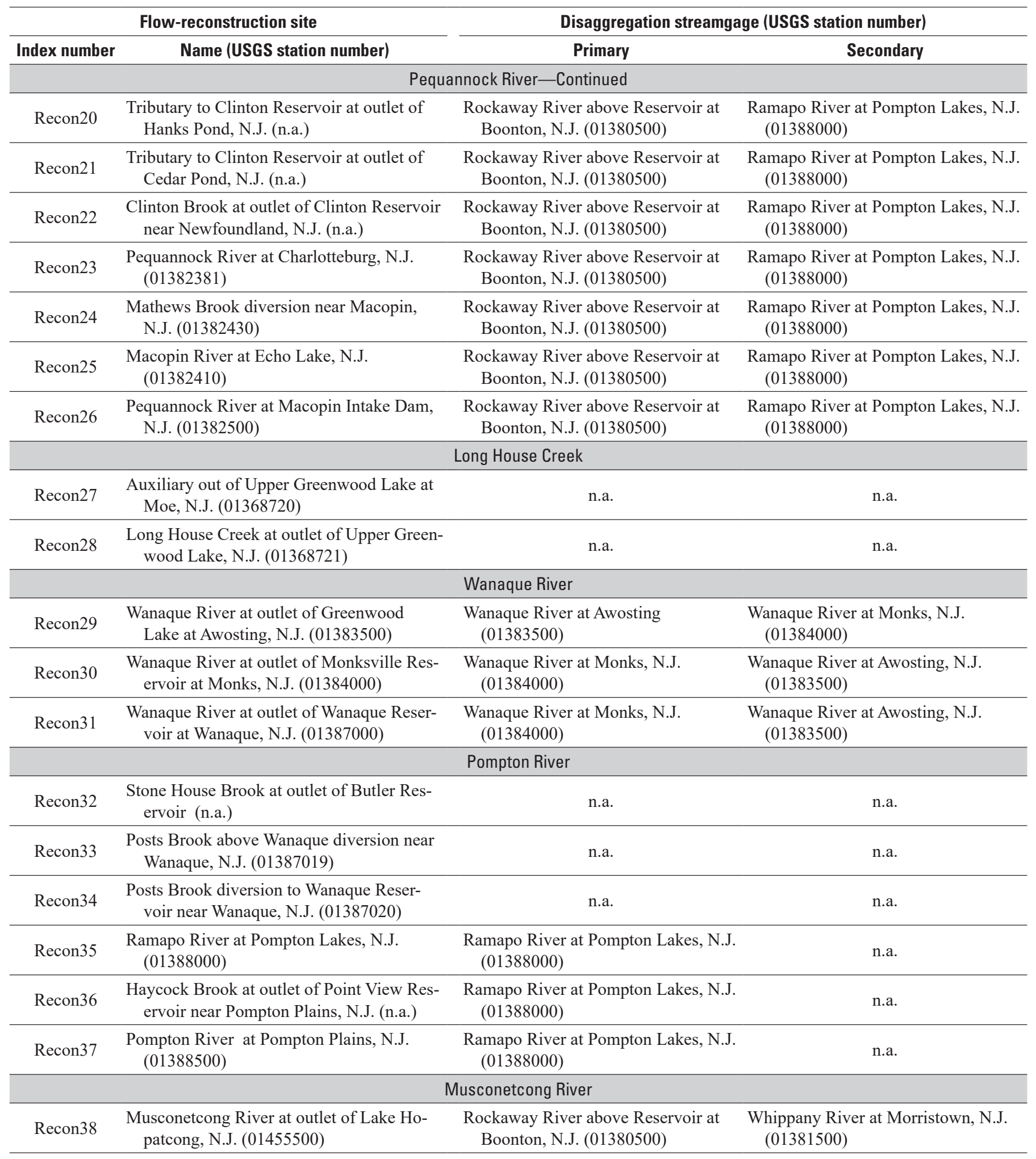


Table 10. Disaggregation streamgages used to determine daily reconstructed flows from monthly reconstructed flows at flowreconstruction sites in northern New Jersey and southeastern New York.-Continued

[n.a., not applicable; N.J., New Jersey; N.Y., New York; USGS, U.S. Geological Survey]

\begin{tabular}{|c|c|c|c|}
\hline \multicolumn{2}{|r|}{ Flow-reconstruction site } & \multicolumn{2}{|c|}{ Disaggregation streamgage (USGS station number) } \\
\hline Index number & Name (USGS station number) & Primary & Secondary \\
\hline \multicolumn{4}{|c|}{ Rockaway River } \\
\hline Recon40 & $\begin{array}{l}\text { Stoney Brook tributary at outlet of Tay- } \\
\text { lortown Reservoir, N.J. (n.a.) }\end{array}$ & $\begin{array}{l}\text { Rockaway River above Reservoir at } \\
\text { Boonton, N.J. (01380500) }\end{array}$ & $\begin{array}{l}\text { Whippany River at Morristown, N.J. } \\
(01381500)\end{array}$ \\
\hline Recon42 & $\begin{array}{l}\text { Rockaway River below Reservoir at Boon- } \\
\text { ton, N.J. }(01381000)\end{array}$ & $\begin{array}{l}\text { Rockaway River above Reservoir at } \\
\text { Boonton, N.J. (01380500) }\end{array}$ & $\begin{array}{l}\text { Whippany River at Morristown, N.J. } \\
(01381500)\end{array}$ \\
\hline \multicolumn{4}{|c|}{ Whippany River } \\
\hline Recon43 & $\begin{array}{c}\text { Harmony Brook at outlet of Clyde Potts } \\
\text { Reservoir near Brookside, N.J. (n.a.) }\end{array}$ & $\begin{array}{l}\text { Whippany River at Morristown } \\
(01381500)\end{array}$ & n.a. \\
\hline Recon45 & $\begin{array}{l}\text { Whippany River at Morristown, N.J. } \\
(01381500)\end{array}$ & $\begin{array}{l}\text { Whippany River at Morristown } \\
(01381500)\end{array}$ & n.a. \\
\hline \multicolumn{4}{|c|}{ Main Stem Passaic River } \\
\hline Recon46 & $\begin{array}{l}\text { Passaic River near Chatham, N.J. } \\
\quad(01379500)\end{array}$ & $\begin{array}{l}\text { Passaic River near Chatham, N.J. } \\
\quad(01379500)\end{array}$ & $\begin{array}{l}\text { Passaic River near Millington, N.J. } \\
\quad(01379000)\end{array}$ \\
\hline Recon47 & $\begin{array}{l}\text { Passaic River at diversion near Summit, N.J. } \\
\text { (n.a.) }\end{array}$ & $\begin{array}{l}\text { Passaic River near Chatham, N.J. } \\
(01379500)\end{array}$ & $\begin{array}{l}\text { Passaic River near Millington, N.J. } \\
(01379000)\end{array}$ \\
\hline Recon48 & $\begin{array}{l}\text { Canoe Brook at diversion near Summit, N.J. } \\
(01379530)\end{array}$ & $\begin{array}{l}\text { Whippany River at Morristown, N.J. } \\
(01381500)\end{array}$ & n.a. \\
\hline Recon49 & $\begin{array}{l}\text { Passaic River at Pine Brook, N.J. } \\
\quad(01381900)\end{array}$ & $\begin{array}{l}\text { Passaic River at Little Falls, N.J. } \\
\quad(01389500)\end{array}$ & n.a. \\
\hline Recon53 & $\begin{array}{l}\text { Passaic River at Little Falls, N.J. } \\
\quad(01389500)\end{array}$ & $\begin{array}{l}\text { Passaic River at Little Falls, N.J. } \\
\quad(01389500)\end{array}$ & n.a. \\
\hline
\end{tabular}




\section{Application of Methods to Flow- Reconstruction Sites in Each Subbasin}

Data types and streamflow adjustment terms used for each flow-reconstruction site are presented in detail for each subbasin. Data types include partial-record streamflow, observed streamflow, or streamflow data determined by drainage area adjustment from nearby sites. Adjustment terms include surface-water diversions and changes in reservoir storage for each site. Subbasins are discussed in groups.

\section{Hackensack River, Saddle River, Hirshfeld Brook, and Sparkill Creek}

Features of these subbasins are shown in figure 4 (map) and figure 10 (schematic diagram of streamflow). Data types used to reconstruct flows at each flow-reconstruction site are presented in table 11. The components of streamflow adjustments are shown in table 12 .

Reconstructed streamflows at sites in the Hackensack River subbasin were determined from monthly streamflows (tables 11 and 12, fig. 10). Reconstructed flows at the following sites were determined from adjustments of observed streamflows: Hackensack River at West Nyack, N.Y.

(Recon04); Hackensack River at Rivervale, N.J. (Recon06); Hackensack River at New Milford, N.J. (Recon09); and Pascack Brook at Westwood, N.J. (Recon08). Streamflow adjustments (diversions and changes in reservoir storage) are presented in table 12. Missing values of change in storage for Woodcliff Lake during water years 1922-30 were set to zero for calculations for Hackensack River at New Milford, N.J. (Recon09). Reconstructed flows at three other sites-Hackensack River at outlet of DeForest Lake at West Nyack, N.Y. (Recon03); Hackensack River at outlet of Lake Tappan at Old Tappan, N.J. (Recon05); and Pascack Brook at Woodcliff Lake outlet at Hillsdale, N.J. (Recon07) - were determined from drainage-area adjustment of flows at one of the previous four sites, as indicated in table 11.

Reconstructed flows at the sites in the Saddle River subbasin were all determined from monthly data (tables 11 and 12, fig. 10). Reconstructed flows at three sites-Saddle River at Upper Saddle River, N.J. (Recon11); Saddle River at Ridgewood, N.J. (Recon12); and Saddle River below Hohokus Brook at Paramus, N.J. (Recon14) — were determined from adjustments of observed flows. Reconstructed flows at the site on the Saddle River below diversion at Paramus, N.J. (Recon13), were determined from drainage-area adjustment of corresponding flows at the site on the Saddle River at Ridgewood, N.J. (Recon12).

Reconstructed flows at the site in the Hirshfeld Brook subbasin (Recon10) were determined from estimated daily observed flows at the partial-record station on Hirshfeld Brook at New Milford, N.J. (01378520), after adjustment for drainage area (table 11, fig. 10). The flow-reconstruction site at the diversion is downstream from this partial-record station.
Reconstructed flows at the two sites in the Sparkill Creek subbasin were determined from monthly data (tables 11 and 12, fig. 10). Reconstructed flows at the streamgage at Sparkill, N.J. (Recon02), were determined from adjustment of observed flows. Reconstructed flows at Sparkill Creek at diversion at Northvale, N.J. (Recon01), were determined from drainage-area adjustment of reconstructed flows at the site at the streamgage (Recon02).

\section{Pequannock River and Double Kill}

Reconstruction sites in the subbasins of the Pequannock River and Double Kill are shown in figures 5 (map) and 11 (schematic diagram of streamflow). Data types for each reconstruction site in the subbasins of the Pequannock River and Double Kill are given in table 13. Components of streamflow adjustment terms are presented in table 14 .

Reconstructed flows at all 11 sites in the Pequannock River subbasin were determined from monthly data (tables 13 and 14, fig. 11). In addition, reconstructed flows at the site on the Pequannock River at Macopin Intake Dam, N.J. (Recon26), were determined by adjustment of observed streamflow measured at this site for changes in storage in five reservoirs and for two diversions. Reconstructed flows at the other 10 sites were determined from drainage-area adjustment of the reconstructed flows at Pequannock River at Macopin Intake Dam, N.J. (Recon26).

Reconstructed flows at the one site in the Double Kill subbasin (Recon15) were determined from drainage-area adjustment of the monthly observed flows at the partial-record station on Double Kill at Wawayanda, N.J. (01368820), (tables 6 and 13, fig. 11). The monthly observed flows at this partial-record station were estimated from discrete streamflow measurements.

\section{Wanaque River and Long House Creek}

Flow-reconstruction sites in the Wanaque River and Long House Creek subbasins are shown in figures 6 (map) and 12 (streamflow schematic diagram). Flow-reconstruction data types are presented in table 15. Streamflow adjustment terms are given in table 16.

Reconstructed flows at the three sites in the Wanaque River subbasin were determined from the adjustment of monthly observed streamflows at each site (tables 15 and 16, fig. 12): Wanaque River at outlet of Greenwood Lake at Awosting, N.J. (Recon29); Wanaque River at outlet of Monksville Reservoir at Monks, N.J. (Recon30); and Wanaque River at outlet of Wanaque Reservoir at Wanaque, N.J. (Recon31). Streamflow was adjusted for diversions and for changes in storage in three reservoirs (table 16). Streamflows measured at the Wanaque River at outlet of Monksville Reservoir at Monks, N.J. (Recon30), were not adjusted for storage in the Monksville Reservoir because the streamgage at this site (01384000) was operated prior to the construction of the reservoir. 
Daily reconstructed flows at the two sites in the Long House Creek subbasin were determined from discrete streamflow measurements at two partial-record stations (table 15, fig. 12). The reconstructed flows at the Auxiliary out of Upper Greenwood Lake at Moe, N.J. (Recon27), were estimated from records from the partial-record station at this site (01368720). The reconstructed flows at the Long House Creek at outlet of Upper Greenwood Lake, N.J. (Recon28), were determined from drainage-area adjustment of daily reconstructed flows determined at the downstream partialrecord station on Long House Creek below Cascade Lake, N.Y. (01368722), from discrete streamflow measurements at this station.

\section{Pompton River}

Flow-reconstruction sites in the subbasin of the Pompton River are shown in figures 7 (map) and 13 (streamflow schematic diagram). Data types used in streamflow reconstruction are presented in table 17. Streamflow adjustment terms for calculation of monthly reconstructed flows are shown in table 18. Streamflow adjustment terms for the upstream streamgage used for calculation of sectional monthly reconstructed flows at one site in the Pompton River subbasin are listed in table 19.

Reconstructed flows at the two sites on Posts Brook were determined from analysis of discrete measurements of streamflow at two partial-record stations (table 17, fig. 13). Reconstructed daily flows at Posts Brook diversion to Wanaque Reservoir near Wanaque, N.J. (Recon34), were determined from estimated daily observed streamflows at the partialrecord station at this site (01387020). Reconstructed daily flows at Posts Brook above Wanaque diversion near Wanaque, N.J. (Recon33), are the sums of estimated daily observed flows of the Posts Brook diversion to Wanaque Reservoir near Wanaque, N.J. (Recon34), and the partial-record station on Posts Brook below diversion to Wanaque Reservoir near Wanaque, N.J. (01387021).

Reconstructed flows at Stone House Brook at outlet of Butler Reservoir, N.J. (Recon32), (table 17, fig. 13) were determined from drainage-area adjustment of monthly reconstructed flows for Beaver Brook at outlet of Splitrock Reservoir, N.J. (Recon39), in the Rockaway River subbasin (table 17, fig. 13). The reconstruction of flows at the site on Beaver Brook is discussed below in section "Rockaway River, Musconetcong River, and Whippany River."

Reconstructed flows at Ramapo River at Pompton Lakes, N.J. (Recon35), and Pompton River at Pompton Plains, N.J. (Recon37), were determined by adjusting monthly measured streamflows at each site (table 17, fig. 13); adjustment terms are shown in table 18. Streamflows at the site on the Ramapo River (Recon35) were adjusted for the diversions on the Ramapo River at Pompton Lakes (Div15 and Div16).
Streamflows at the site on the Pompton River (Recon37) were adjusted for diversions in the subbasins of the Pompton River and for diversions and changes in reservoir storage upstream from the Pequannock River at Macopin Intake Dam, N.J. (Recon26), and Wanaque River at Wanaque, N.J. (Recon31).

Reconstructed flows at Haycock Brook at outlet of Point View Reservoir near Pompton Plains, N.J. (Recon36), were determined from drainage-area adjustment of sectional monthly reconstructed flows between Ramapo River at Pompton Lakes, N.J., and Ramapo River near Mahwah, N.J., (Recon35sec) (table 17). Adjustment terms for the determination of sectional monthly reconstructed flows for the Ramapo River at Pompton Lakes, N.J. (Recon35sec), are presented in table 19.

\section{Rockaway River, Musconetcong River, and Whippany River}

Flow-reconstruction sites in the subbasins of the Rockaway, Musconetcong, and Whippany Rivers are shown in figures 8 (map) and 14 (streamflow schematic diagram). Data types used in flow reconstruction are presented in table 20; streamflow adjustment terms are shown in table 21.

Reconstructed flows at all sites in the subbasins of the Rockaway, Musconetcong, and Whippany Rivers were determined from monthly data (table 20, fig. 14). Reconstructed flows at six sites were determined by adjusting observed streamflows at each site: Musconetcong River at outlet of Lake Hopatcong, N.J. (Recon38); Beaver Brook at outlet of Splitrock Reservoir near Hibernia, N.J. (Recon39); Rockaway Rive above Reservoir at Boonton, N.J. (Recon41); Rockaway River below Reservoir at Boonton, N.J. (Recon42); Whippany River near Morristown, N.J. (Recon44); and Whippany River at Morristown, N.J. (Recon45). Streamflow adjustment terms are presented in table 21.

Monthly flow adjustment and monthly reconstructed flows at Rockaway River above Reservoir at Boonton, N.J. (Recon41), and Rockaway River below Reservoir at Boonton, N.J. (Recon42), were calculated with some missing values of changes in storage in Splitrock Reservoir set to zero. This period of record is water years 1922-49 (table 3).

Reconstructed flows at one site in the Rockaway River subbasin and one site in the Whippany River subbasin were determined from drainage-area adjustment of monthly reconstructed flows at other sites (fig. 14, table 20). Reconstructed streamflows at Stony Brook tributary at outlet of Taylortown Reservoir, N.J. (Recon40), were determined by drainage area adjustment of reconstructed flows in Beaver Brook at outlet of Splitrock Reservoir near Hibernia, N.J. (Recon39). Reconstructed flows at Harmony Brook at outlet of Clyde Potts Reservoir near Brookside, N.J. (Recon43), were determined from reconstructed flows for the Whippany River near Morristown, N.J. (Recon44). 


\section{Main Stem Passaic River}

Flow-reconstruction sites in the Main Stem Passaic River subbasin are shown in figures 9 (map) and 15 (streamflow schematic diagram). Data types used for reconstruction at each site are presented in table 22; streamflow adjustment terms are shown in table 23.

Reconstructed flows at all sites in the subbasin of the Main Stem Passaic River were determined from monthly data (tables 22 and 23, fig. 15). Reconstructed flows at the following four sites in the subbasin of the Main Stem Passaic River were determined from adjustment of monthly observed streamflow: Passaic River near Chatham, N.J. (Recon46); Canoe Brook near Summit, N.J. (Recon48); Passaic River at Pine Brook, N.J. (Recon49); and Passaic River at Little Falls, N.J. (Recon53).

Reconstructed flows at Passaic River at Little Falls, N.J. (Recon53), were calculated with some missing diversions set to zero (table 23). The diversions are Passaic River diversion near Summit, N.J. (Div21), and Canoe Brook diversion near Summit, N.J. (Div22). The periods of missing values set to zero are water years 1922-65 and 1975-78 (table 4).

Reconstructed flows at two sites in the Main Stem Passaic River subbasin were determined from drainage-area adjustment of flows at other sites (table 22, fig. 15). Flows at the Passaic River at diversion near Summit, N.J. (Recon47), were determined from those at the Passaic River near Chatham, N.J. (Recon46). Flows at the Passaic River above Beatties Dam at Little Falls, N.J. (Recon52), were determined from those at the Passaic River at Little Falls, N.J. (Recon53). Reconstructed flows at Passaic River at Pine Brook, N.J. (Recon49), were determined by summing sectional monthly reconstructed flows (table 22) and reconstructed flows at upstream sites (tables 22 and 19).

Reconstructed flows at the Passaic River at Two Bridges, N.J. (Recon50), were determined by summing sectional reconstructed flows for the site with monthly reconstructed flows at Passaic River at Pine Brook, N.J. (Recon49) (table 22). Sectional monthly reconstructed flows at the Passaic River at Two Bridges, N.J. (Recon50), were estimated from drainage-area adjustment of sectional monthly reconstructed flows at Passaic River at Little Falls, N.J. (table 19).

Reconstructed flows at the Pompton River at Two Bridges, N.J. (Recon51), were determined by summing sectional reconstructed flows for the site with monthly reconstructed flows at Pompton River at Pompton Plains, N.J. (Recon37) (table 22). Sectional monthly reconstructed flows at Pompton River at Two Bridges, N.J. (Recon51), were estimated from drainage-area adjustment of sectional monthly reconstructed flows at Passaic River at Little Falls, N.J. (Recon53sec) (table 19). 


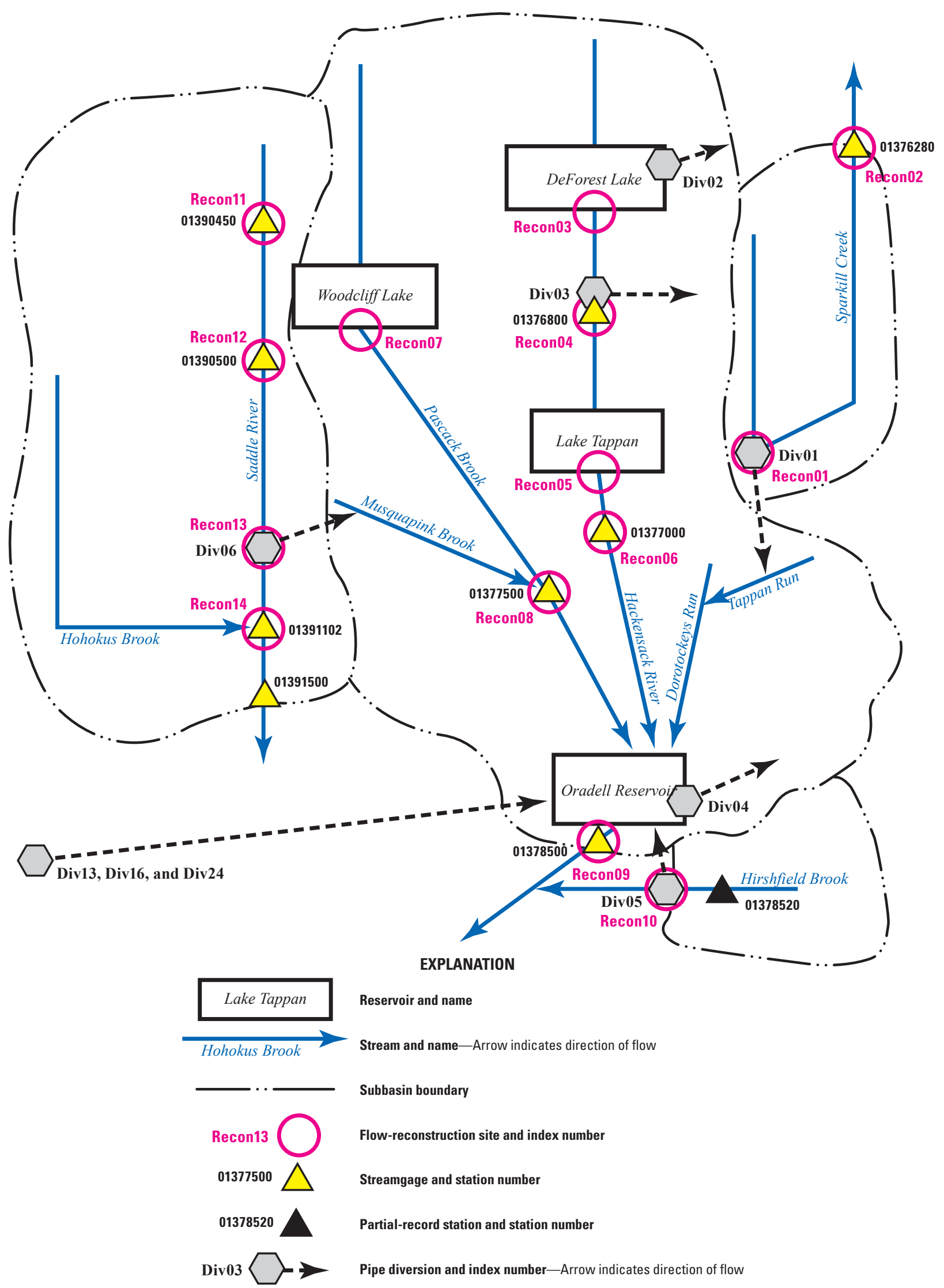

Figure 10. Streamflow in the subbasins of the Hackensack River, Saddle River, Hirshfeld Brook, and Sparkill Creek, northern New Jersey and southeastern New York. 


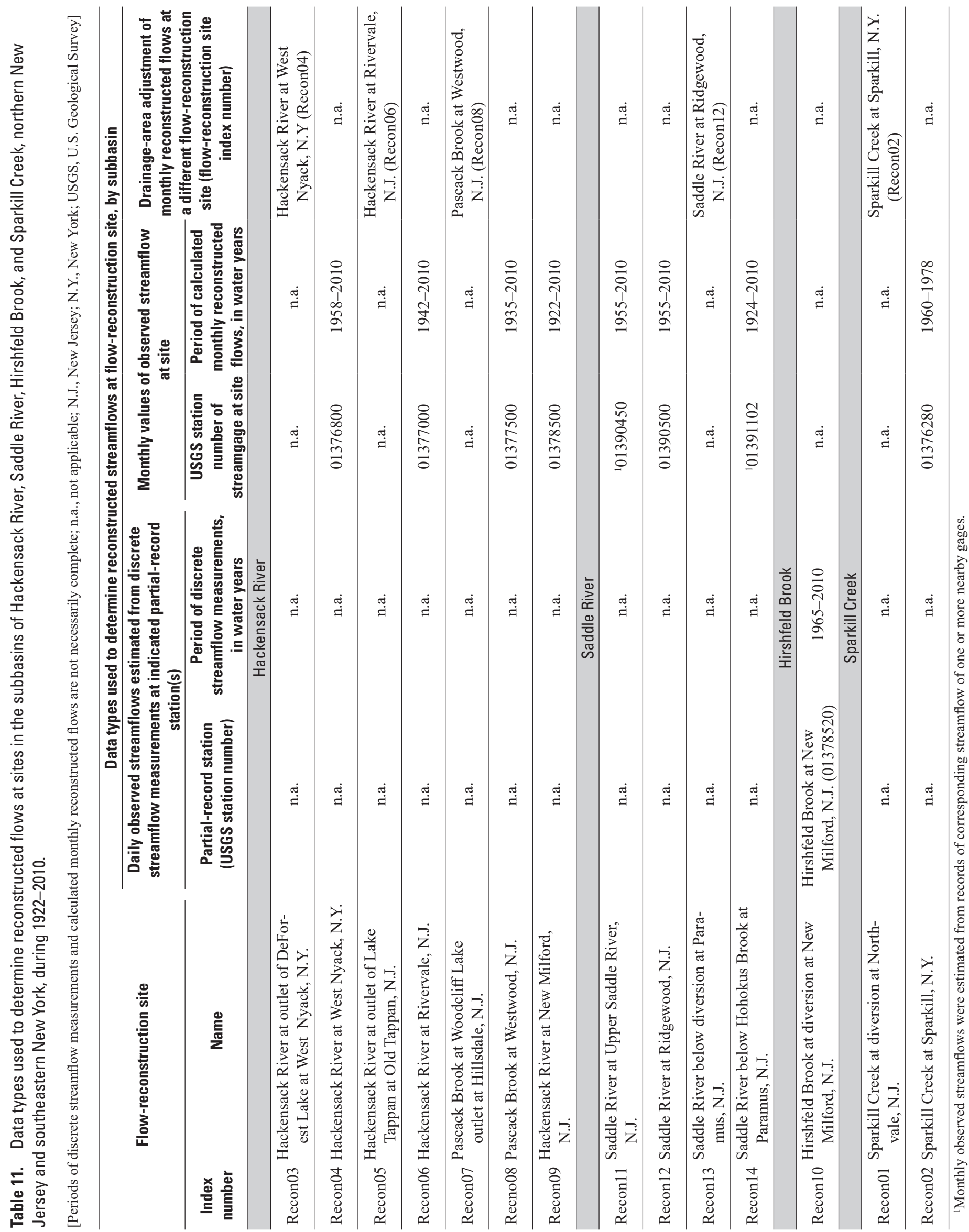




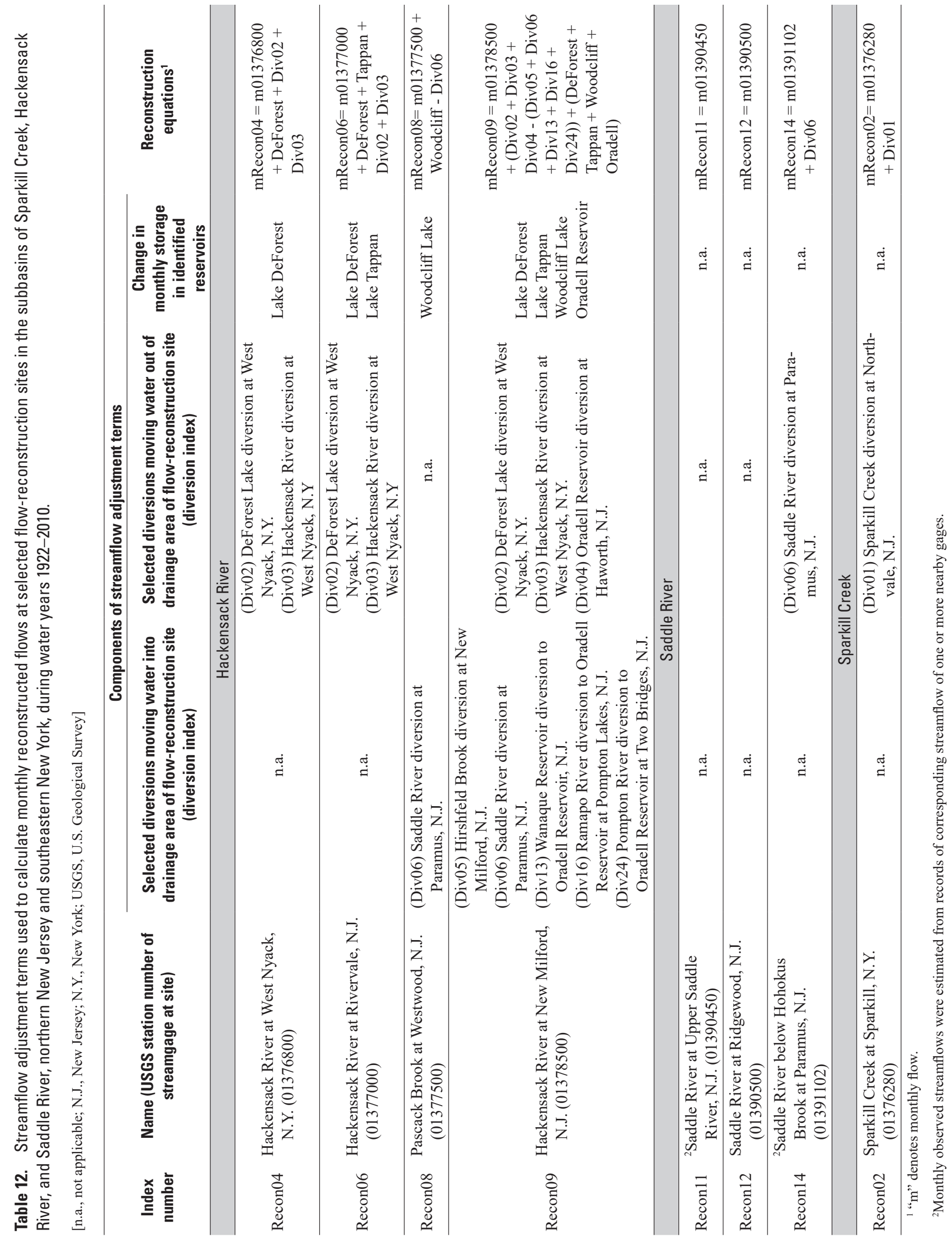




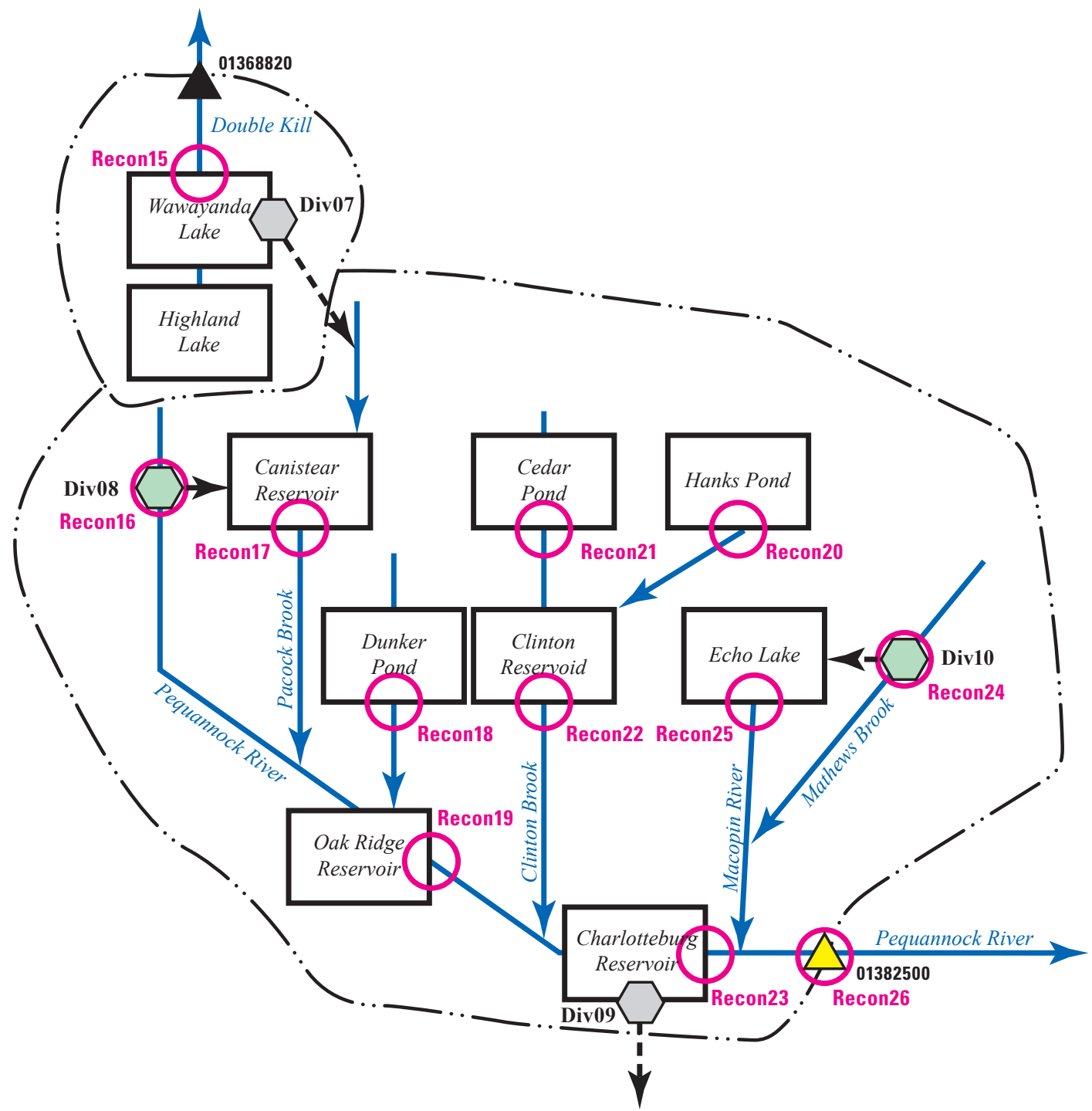

EXPLANATION

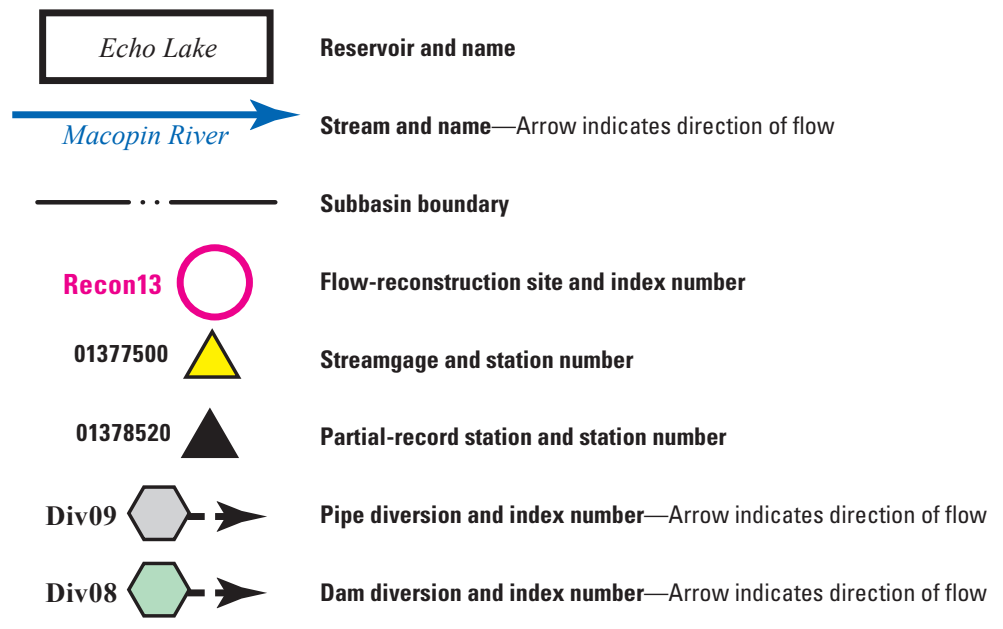

Figure 11. Streamflow in the subbasins of the Pequannock River and Double Kill, northern New Jersey. 


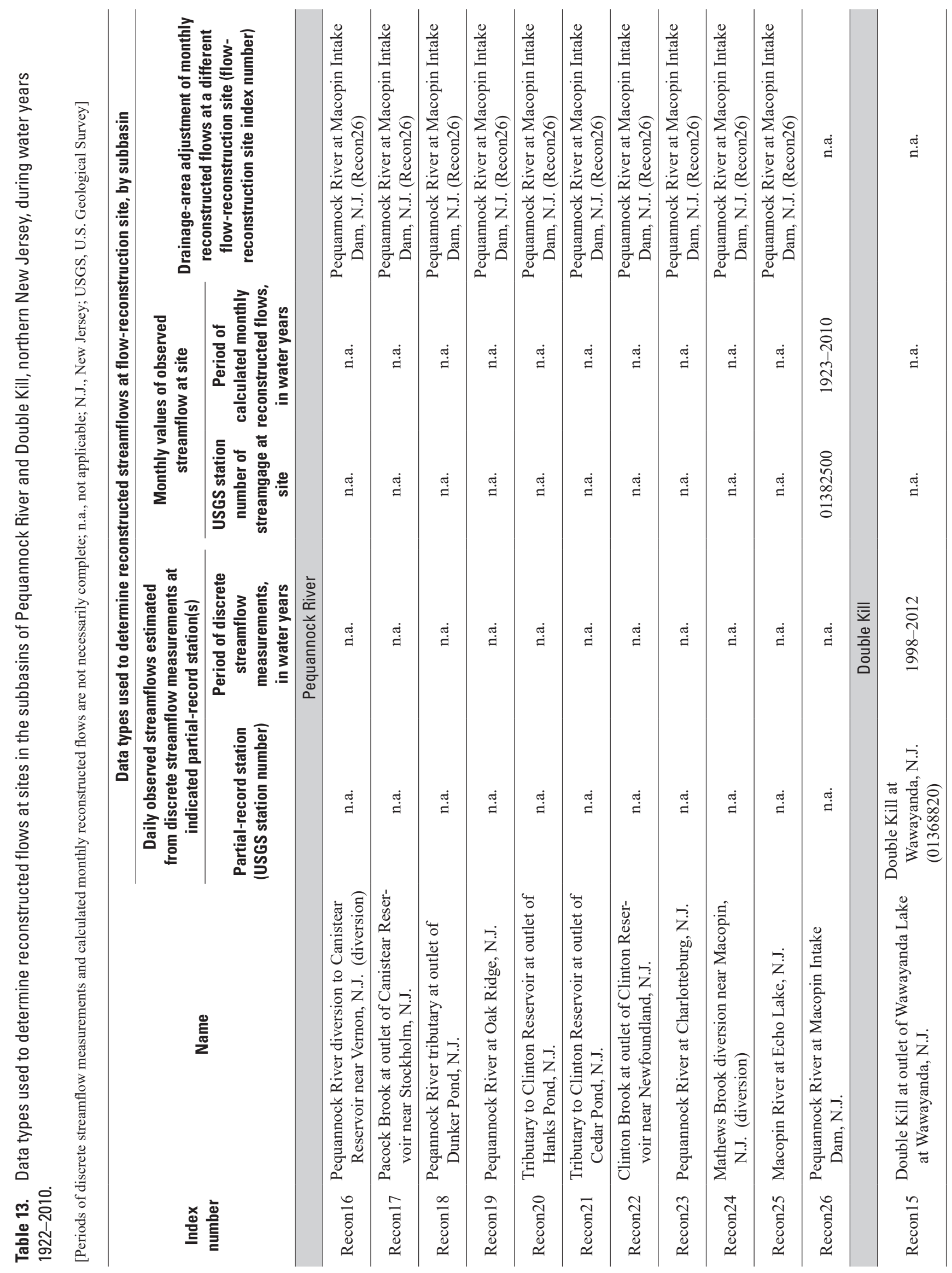




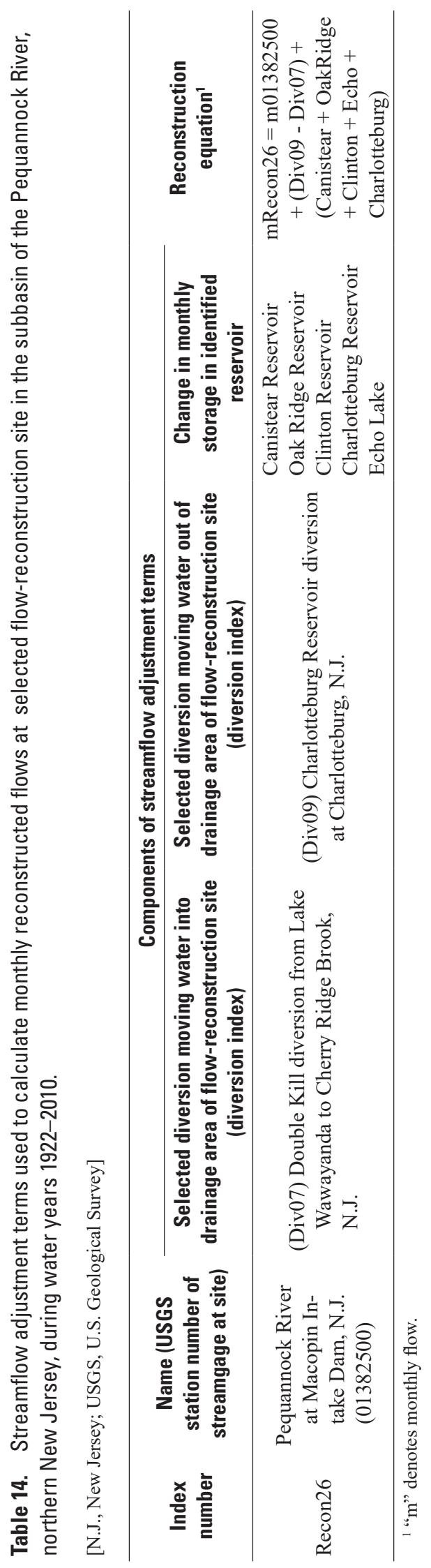



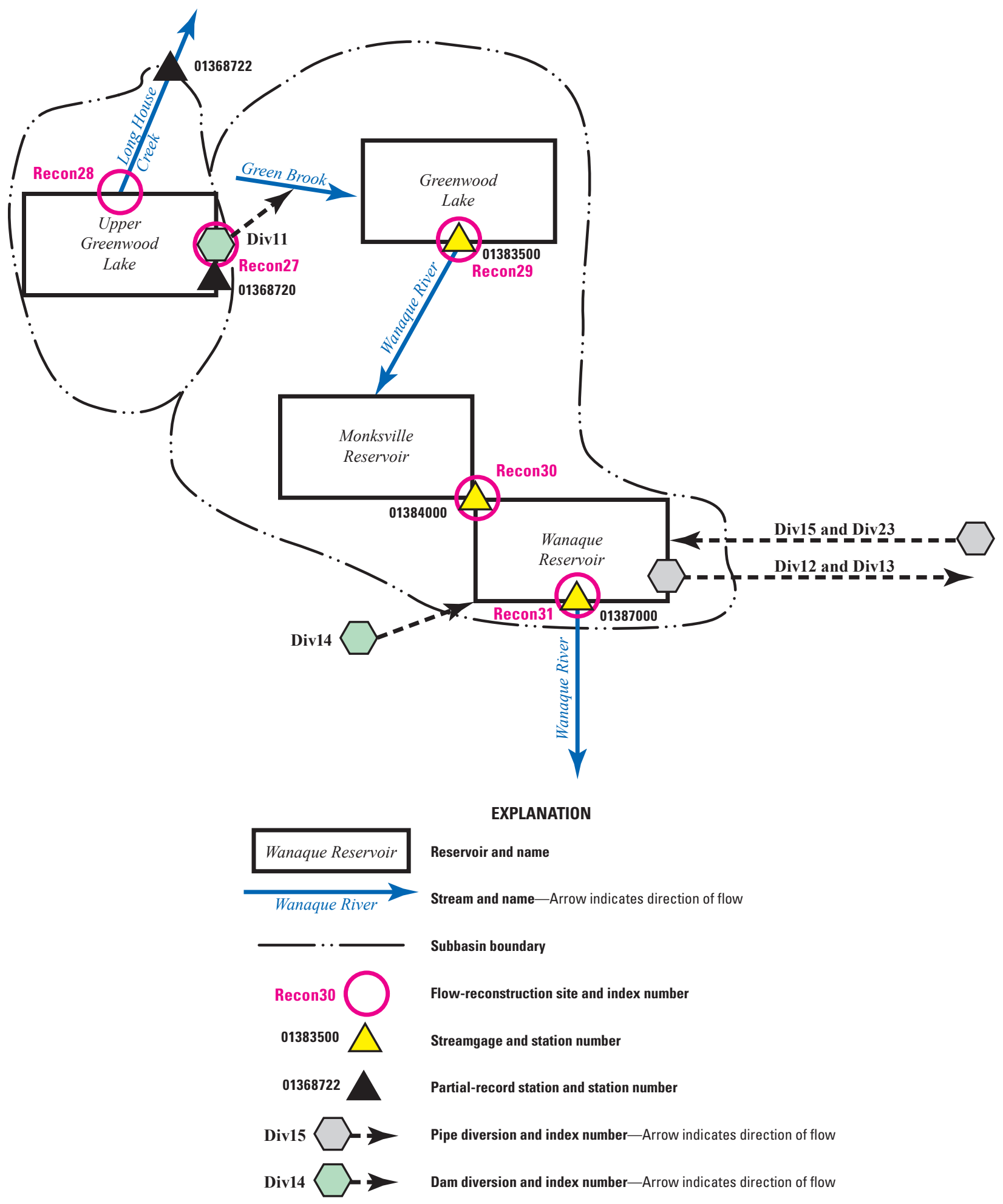

Figure 12. Streamflow in the subbasins of the Wanaque River and Long House Creek, northern New Jersey and southeastern New York. 


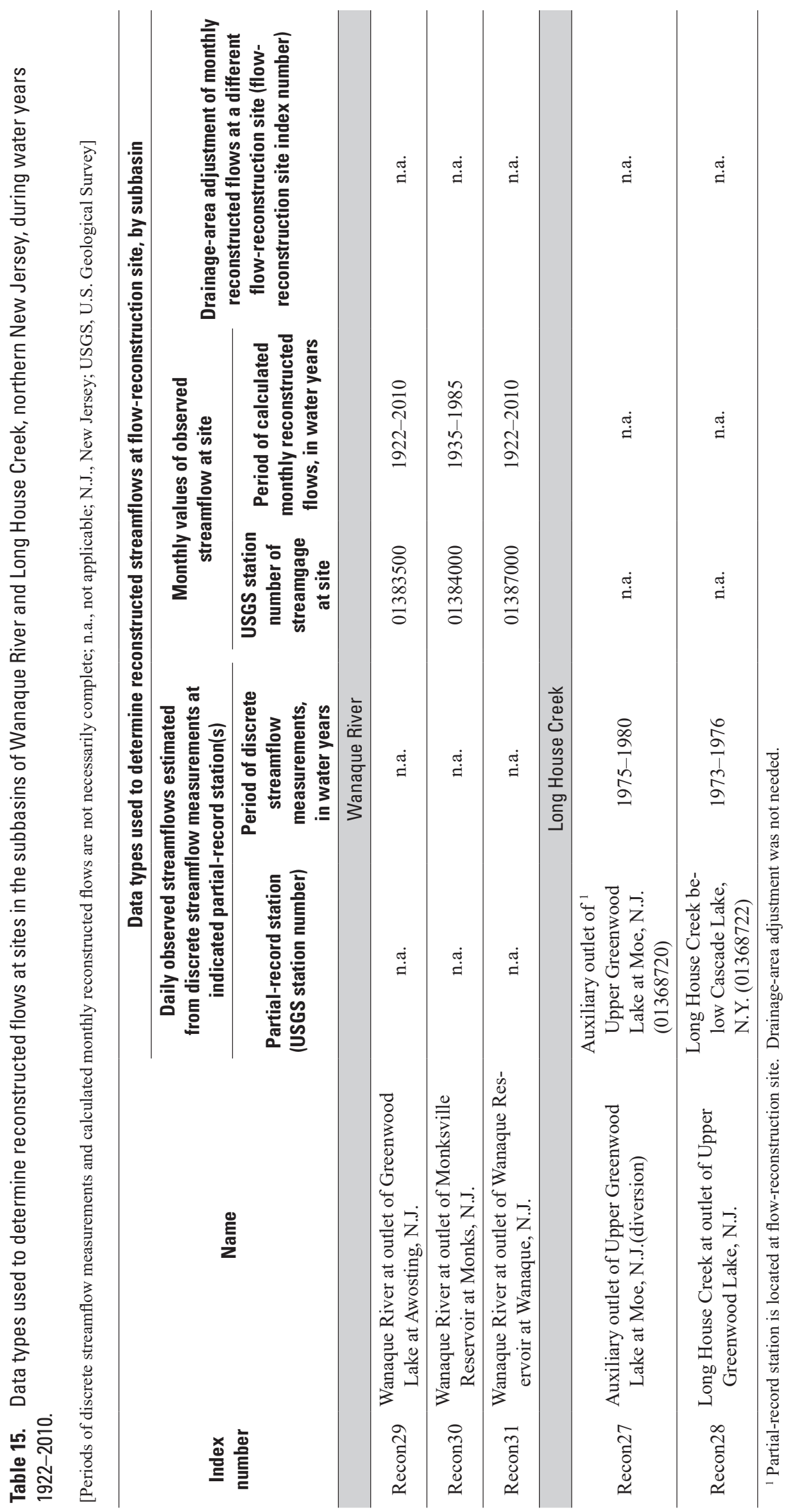




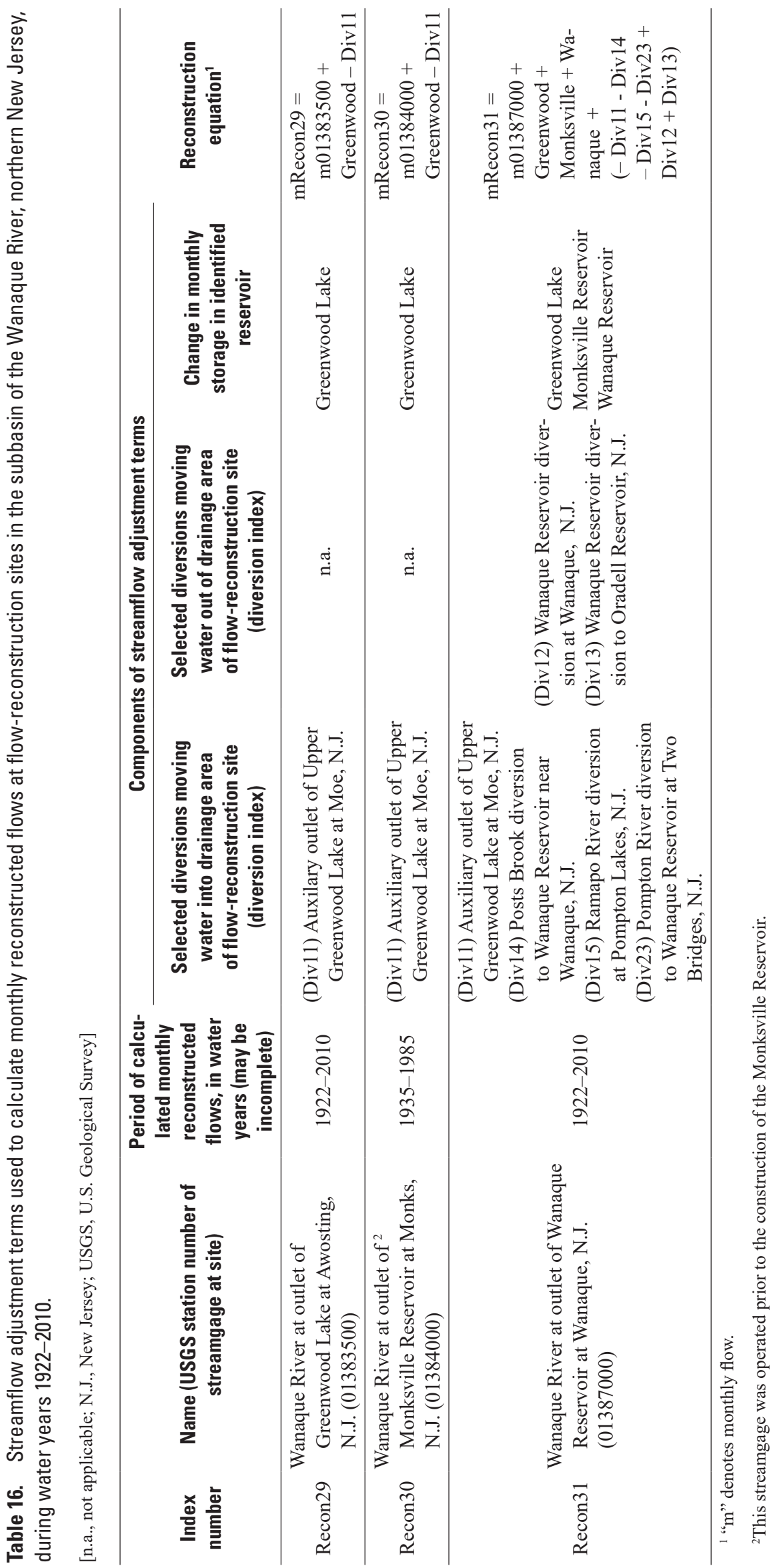




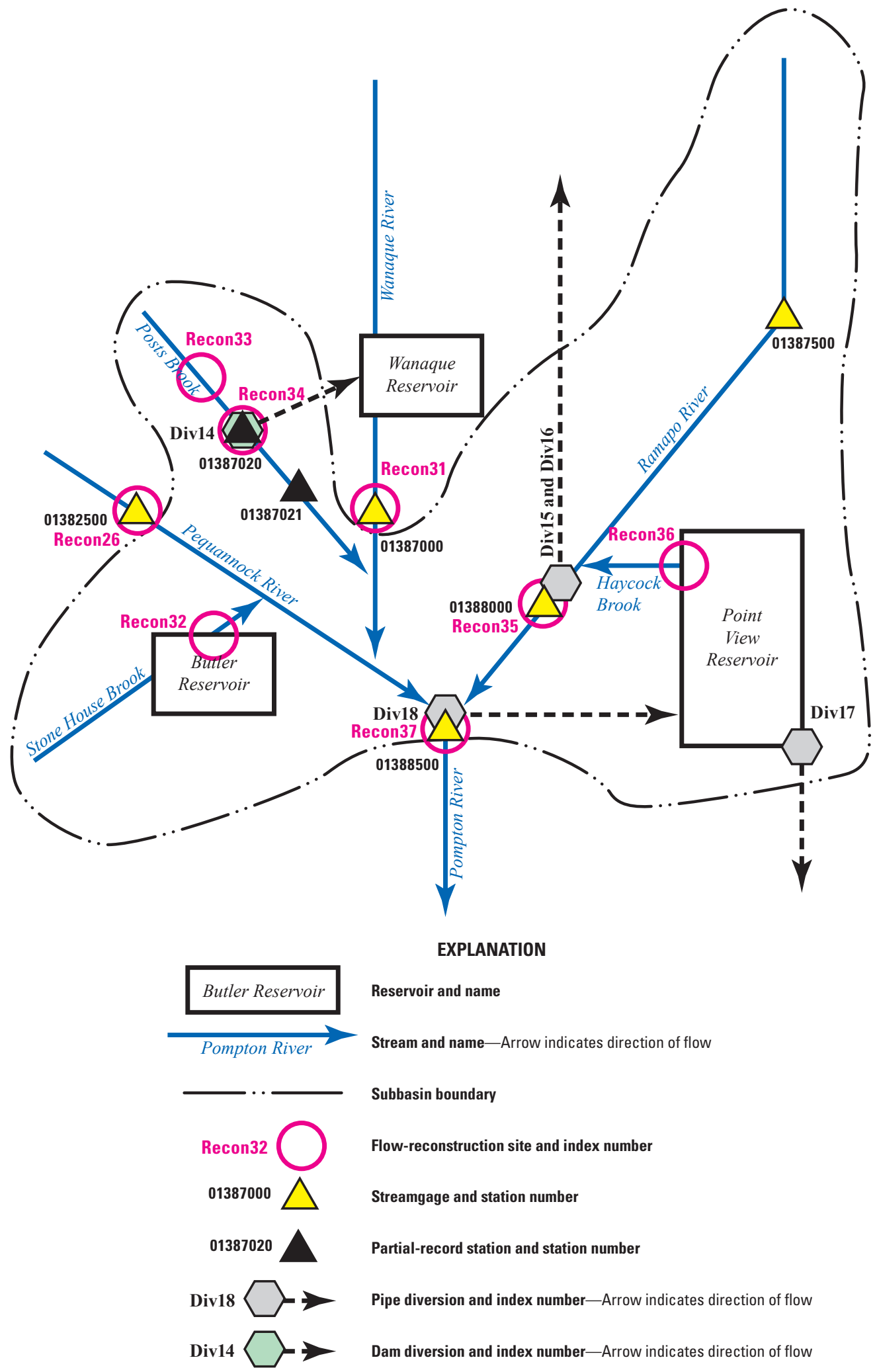

Figure 13. Streamflow in the Pompton River subbasin, northern New Jersey. 


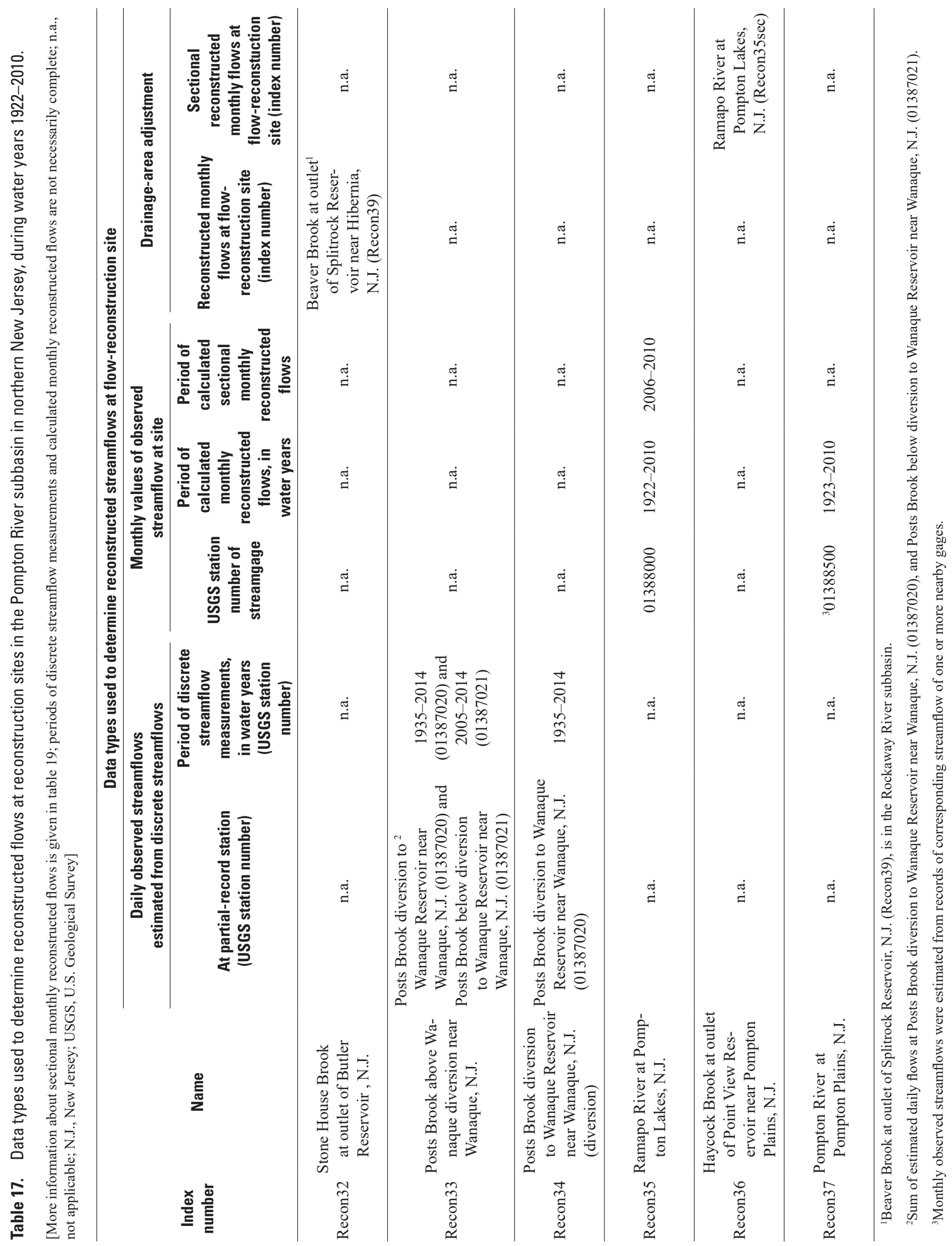




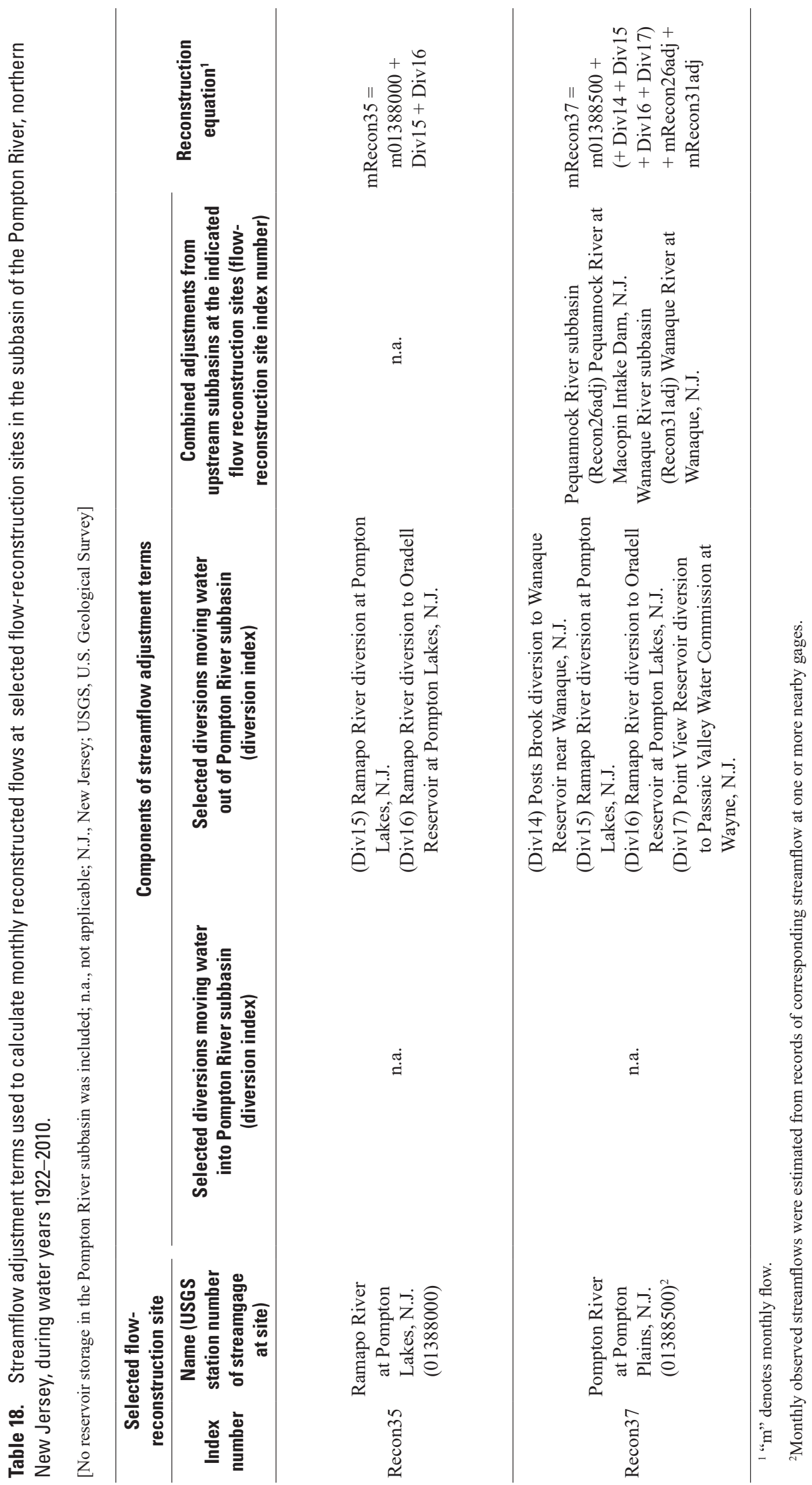


त

$\sum_{0}^{\infty}$

Ф

닐

ธัธิ

ஹ一ำ

的

$\stackrel{\Phi}{\stackrel{\Phi}{\infty}}$

त

을 3

幽.

离

す⿹े

তั

웅

这

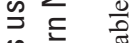

岁 垔

范 응

空

离

E⿱

造

政

을 을

它

क)

屯

든

窝

중

วั을 온

产 잉

离壳

क

कृ $\frac{\mathscr{c}}{\mathrm{c}}$

흔 造

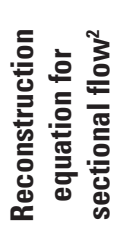

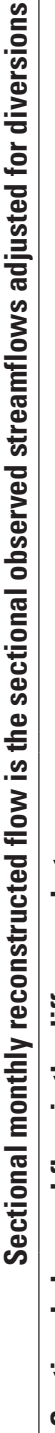
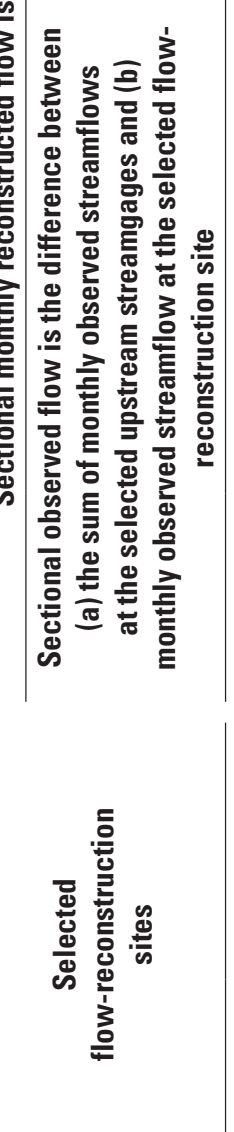


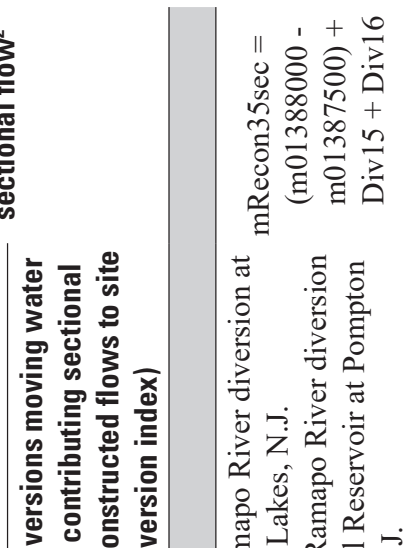

胥造造

递㐫言

c

产

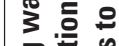

.
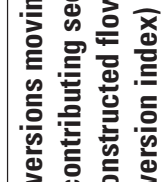

웡

造

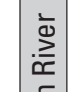

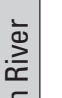

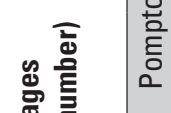

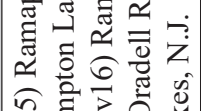

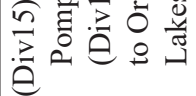

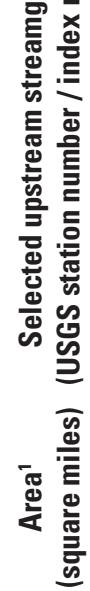

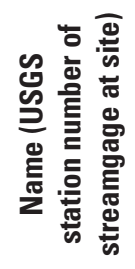

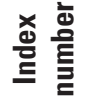

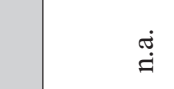

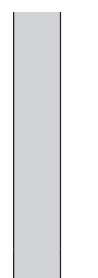

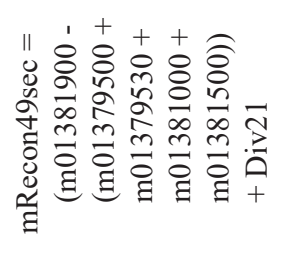

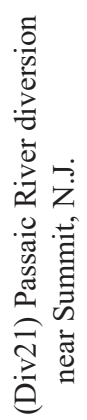
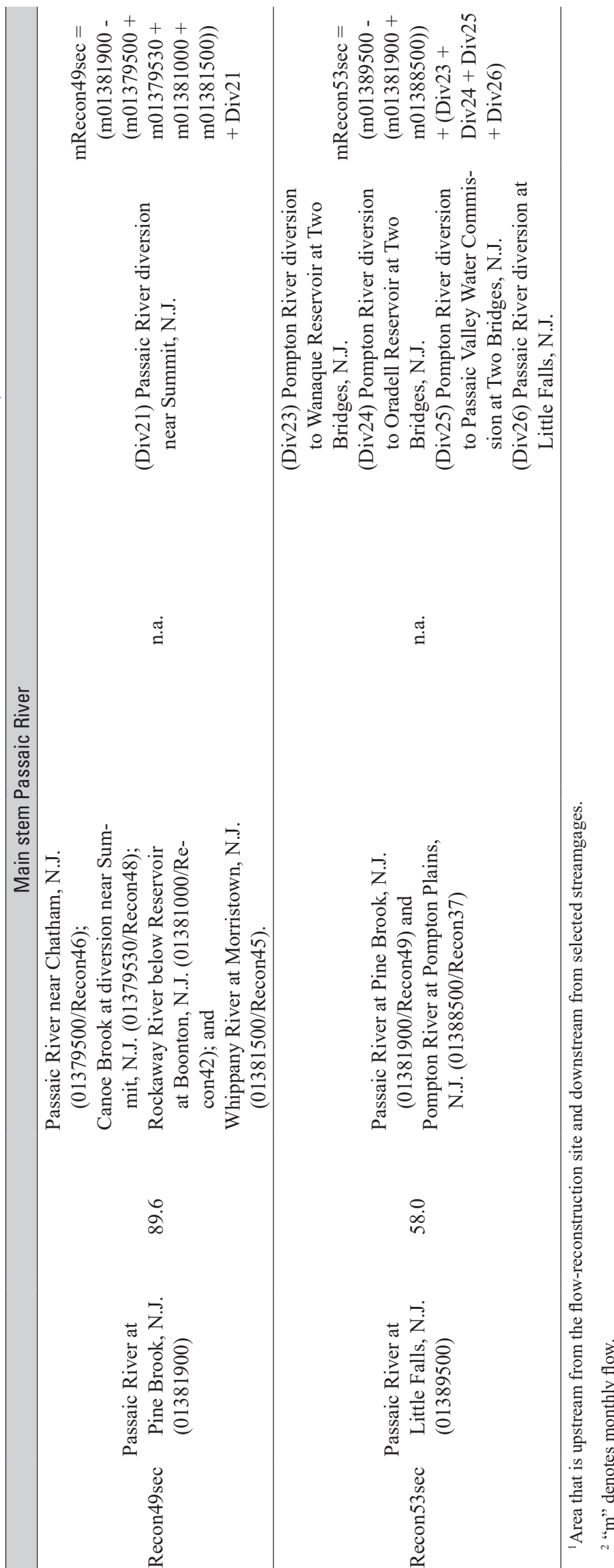


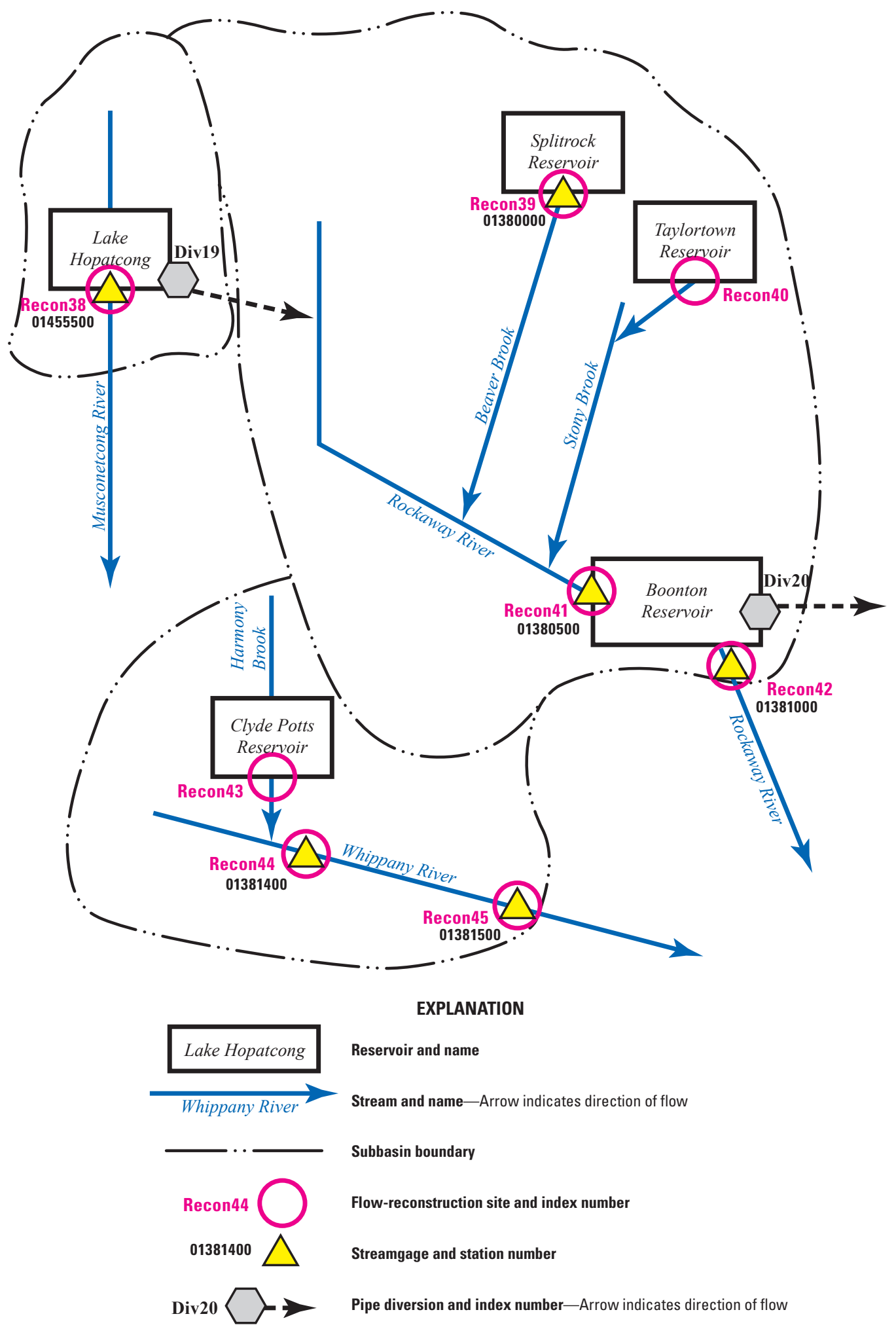

Figure 14. Streamflow in the subbasins of the Rockaway, Musconetcong, and Whippany Rivers, northern New Jersey. 


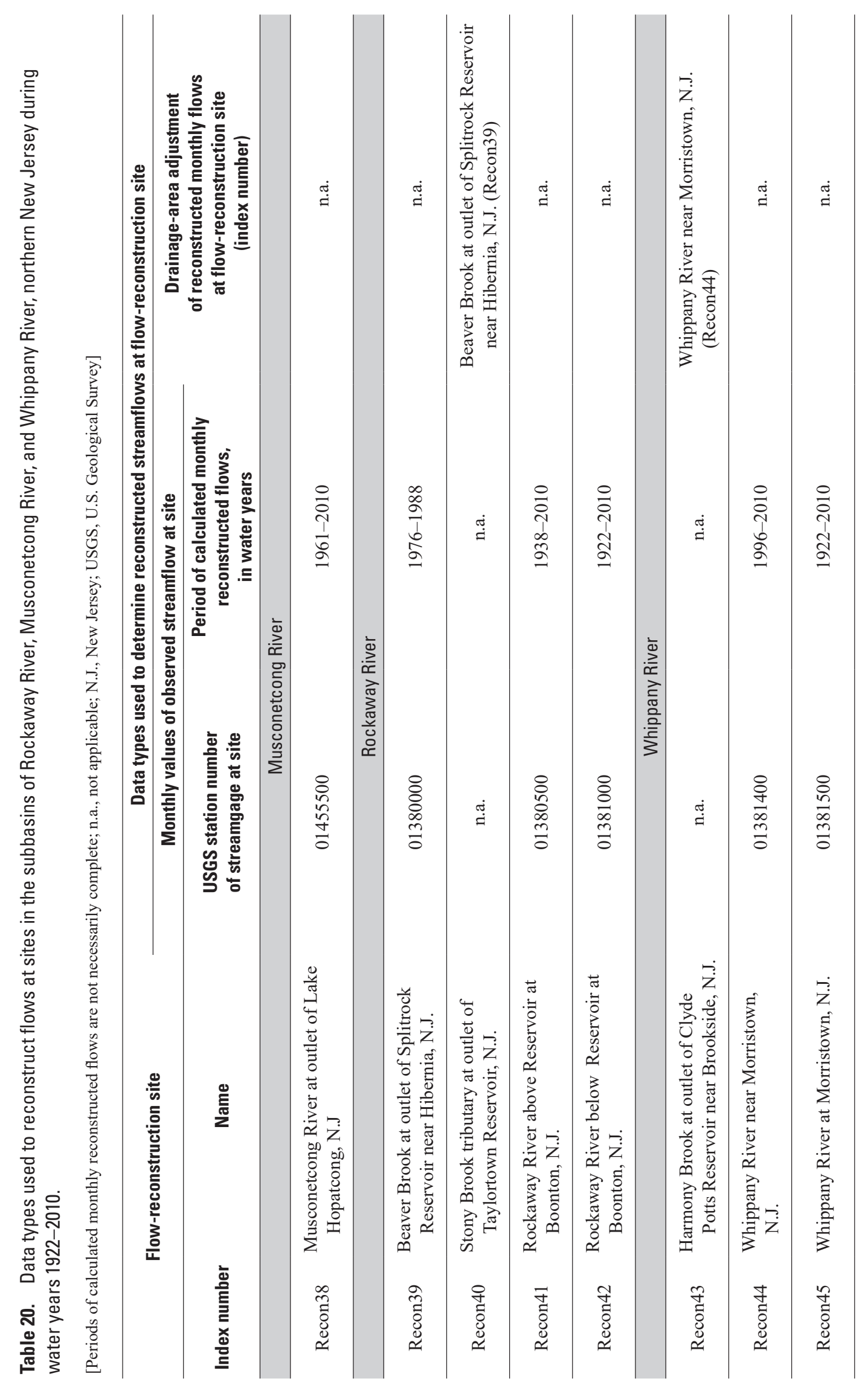




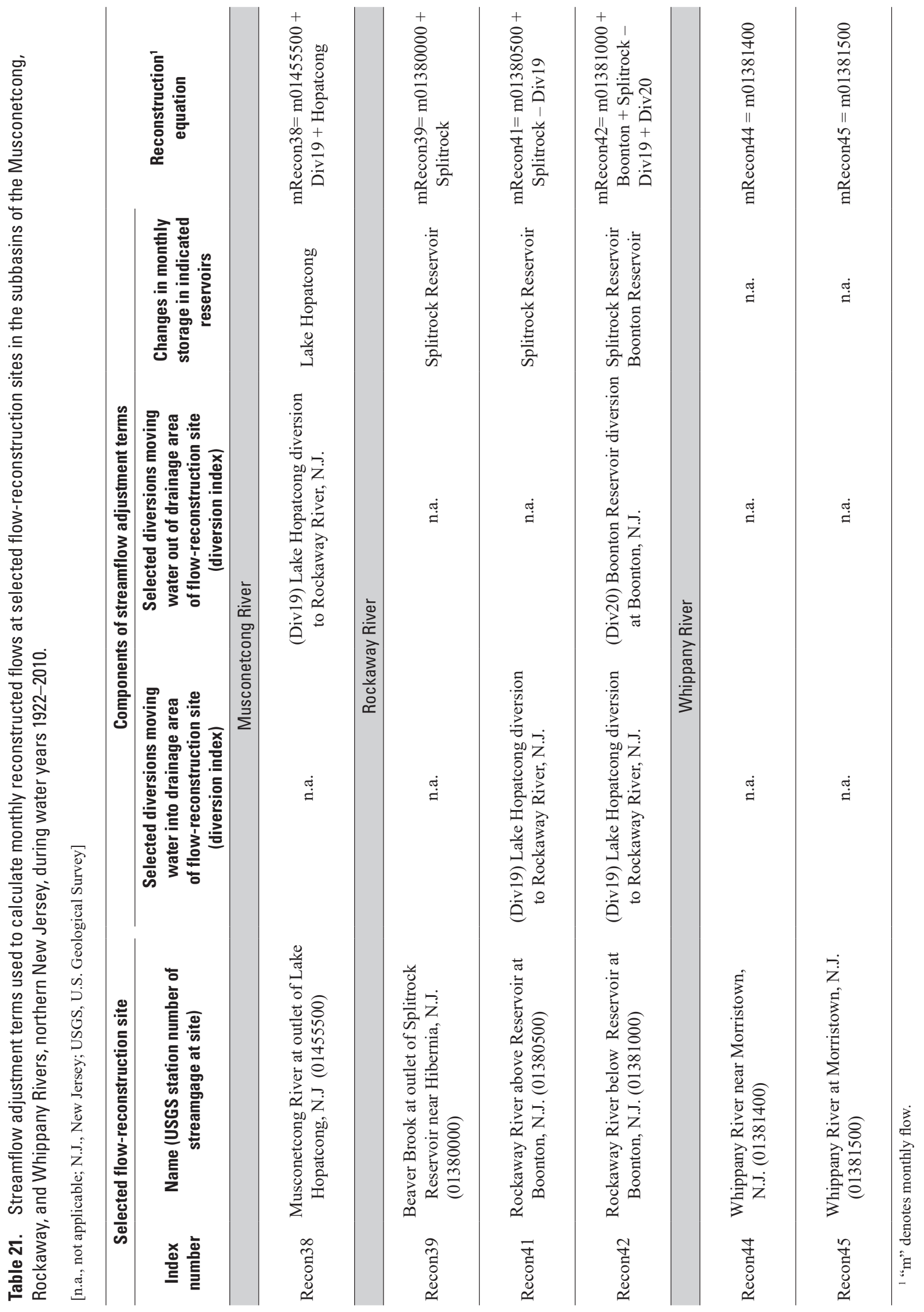




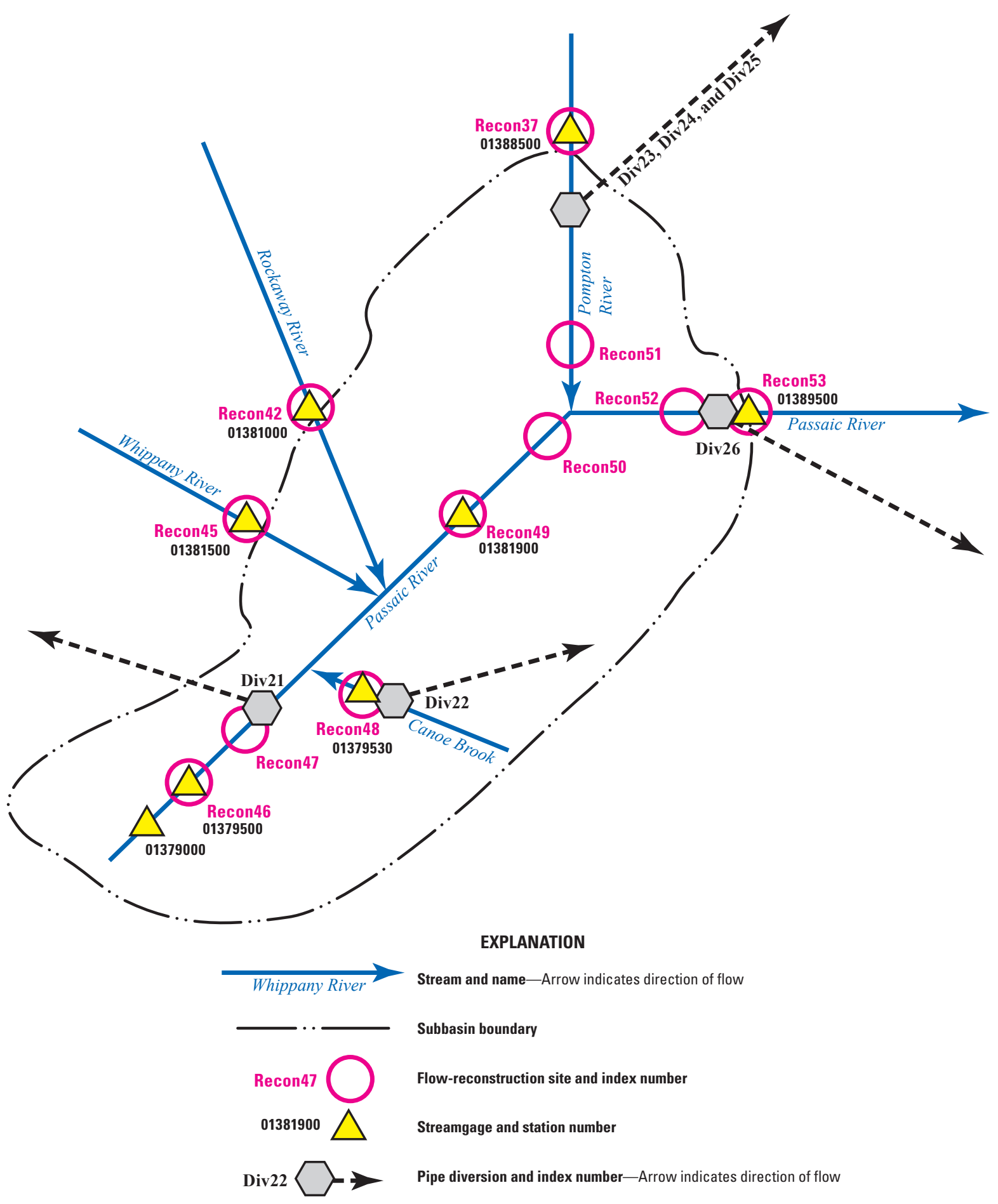

Figure 15. Streamflow in the Main Stem Passaic River subbasin, northern New Jersey. 


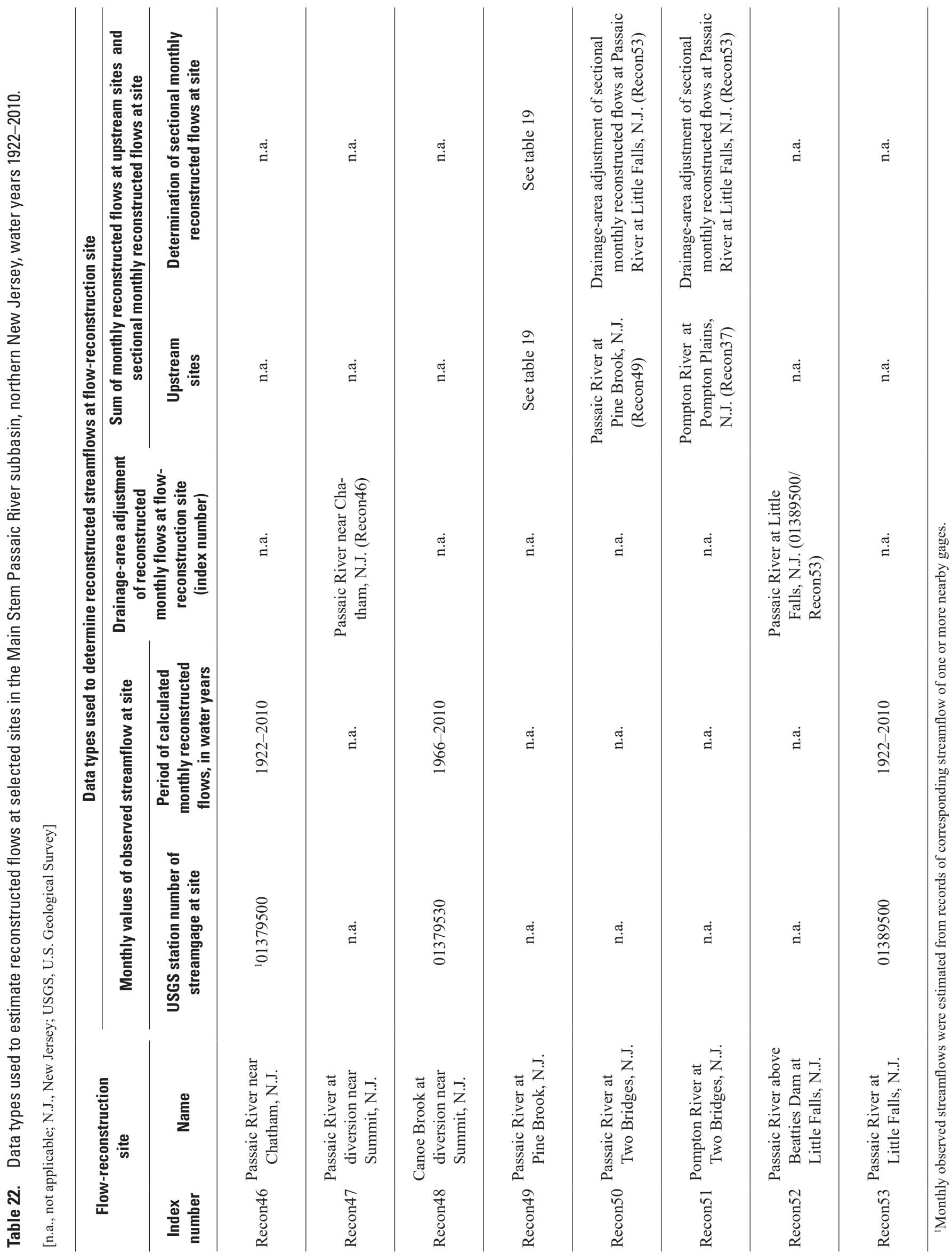




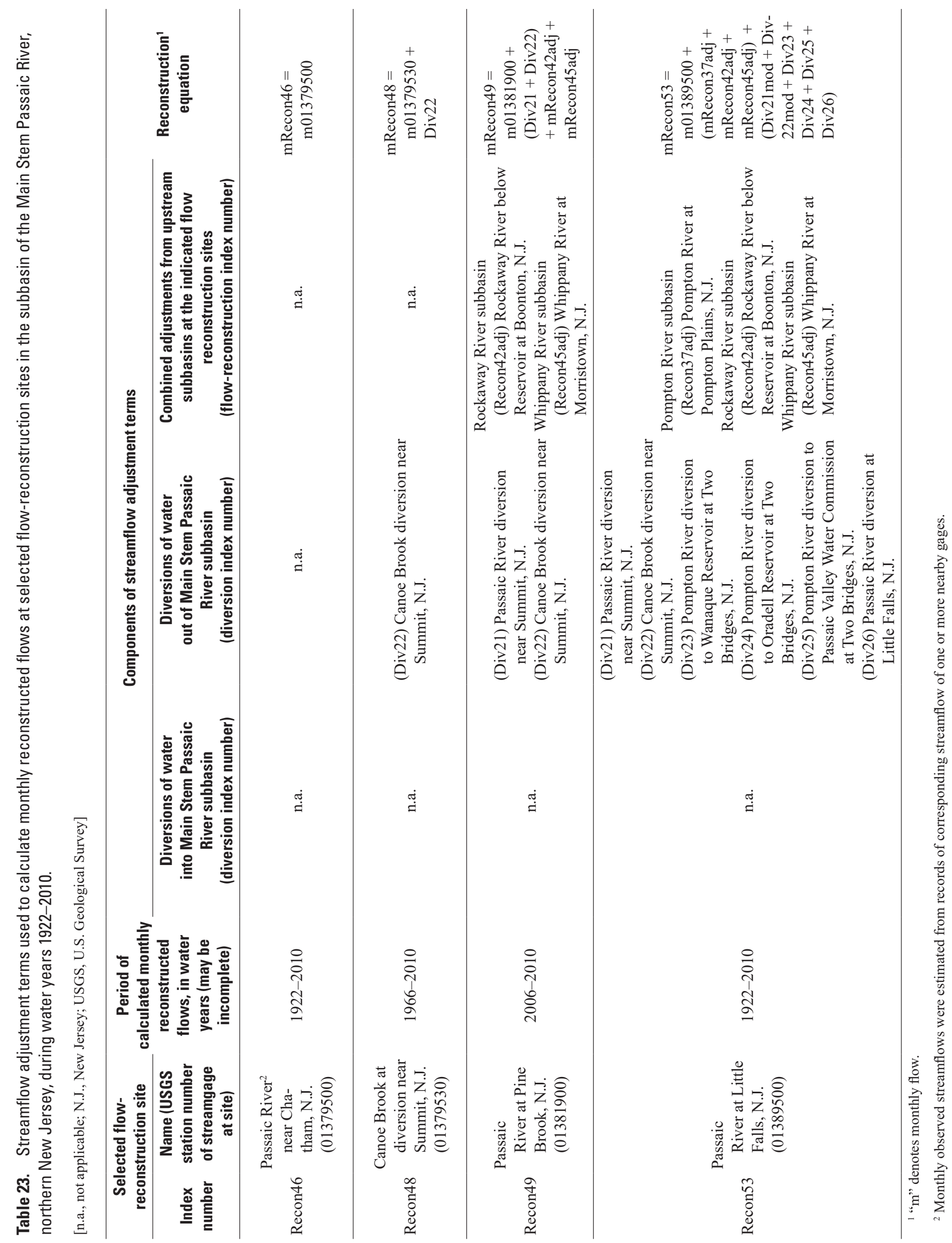




\section{Limitations and Assessment of Reconstructed Flows}

The implications of the methods used to determine monthly and daily reconstructed flows and the reconstructed flows themselves are discussed in the following sections. Information about the data release associated with this report is then presented.

\section{Calculation of Monthly Reconstructed Flows from Observed Streamflow, Changes in Reservoir Storage, and Surface-Water Diversions}

The calculated monthly reconstructed flows in this report (and, by extension, daily reconstructed flows determined from them) include only the effects on streamflow resulting from reservoir storage and surface-water withdrawals by purveyors. Other effects, such as those from groundwater diversions and point-source discharges, are not included. The absence of these effects means that reconstructed flows may be overestimated downstream from groundwater withdrawals or may be underestimated downstream from wastewater-treatment-plant discharges. More information on groundwater withdrawals and point-source discharges can be found in Storck and Nawyn (2001).

At some sites, negative values of monthly reconstructed flows were calculated by adjusting monthly observed streamflows for diversions and changes in reservoir storage. These negative values nearly always occurred under low-flow conditions and likely are due to errors in streamflow or in the terms used to determine the flow adjustment terms. Negative values also may be due to the failure to include all diversions or reservoirs in the calculations. Daily reconstructed flows determined from negative monthly reconstructed flows were set to zero.

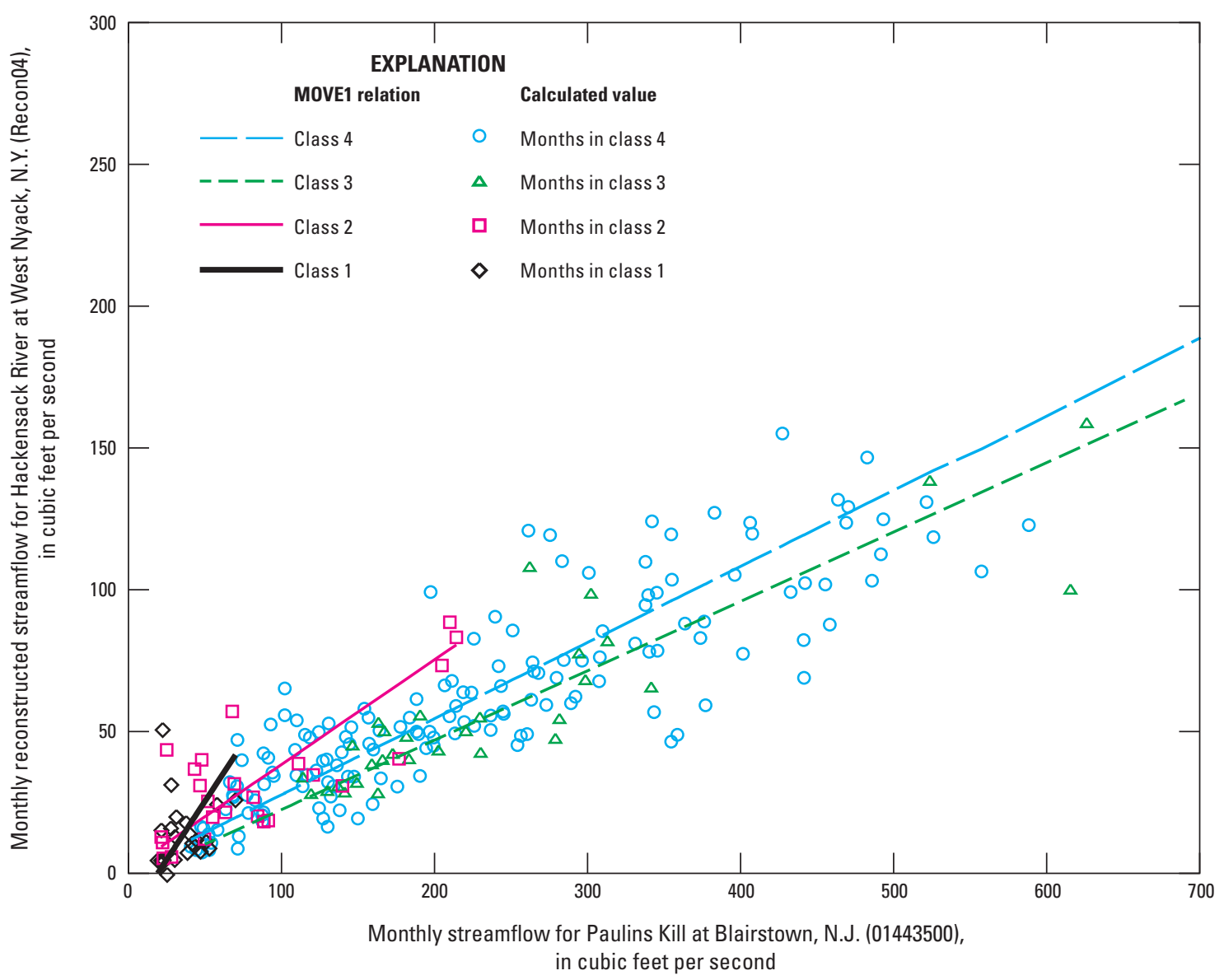

Figure 16. Monthly reconstructed streamflows in the Hackensack River at West Nyack, N.Y. (01376800/Recon04) as a function of monthly streamflows in Paulins Kill at Blairstown, N.J. (01443500), water years 1959-79. 


\section{Estimation of Monthly Reconstructed Flows and Sectional Monthly Reconstructed Flows from Relations with Monthly Observed Flows at Index Gages}

Hydrologic classes were used to group months in order to develop more accurate relations between calculated monthly reconstructed streamflows (or sectional reconstructed flows) and monthly observed streamflows at each index gage. An example of the relation for each hydrologic class between calculated reconstructed monthly flows at the Hackensack River at West Nyack, N.J. (Recon04), and monthly observed streamflows at Paulins Kill at Blairstown, N.J. (01443500), during water years 1959-79 is shown in figure 16.

As a second example, the relation between sectional monthly reconstructed streamflows at Passaic River at Little Falls, N.J. (Recon53), and monthly observed streamflows at Paulins Kill at Blairstown, N.J. (01443500), for water years $2006-10$ is shown in figure 17. Only one relation was developed for these data.

The use of these relations to estimate monthly reconstructed flow may produce values greater or less than actual values if there have been changes in streamflow resulting from changes in basin characteristics between the period of

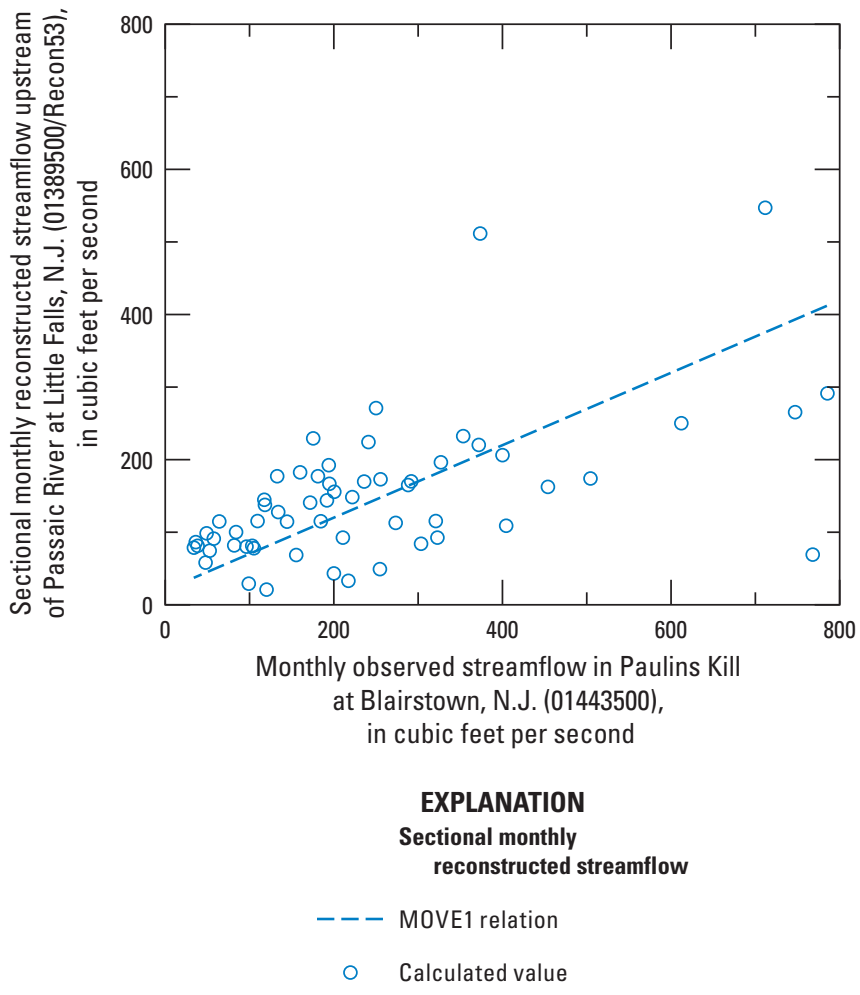

Figure 17. Sectional monthly reconstructed flows upstream from the Passaic River at Little Falls, N.J. (01389500/Recon53), as a function of monthly observed streamflow in the Paulins Kill at Blairstown, N.J. (01443500), water years 2006-10. calculated reconstructed flows used to create the relations and the period for which monthly reconstructed flows were estimated. Streamflow can be affected by changes in such basin characteristics as land use, point-source discharges, and groundwater withdrawals. This bias in estimated monthly reconstructed flows is also present in the daily reconstructed flows determined from them.

\section{Determination of Daily Reconstructed Flows from Disaggregation of Monthly Reconstructed Flows}

Disaggregation streamgages used to determine daily reconstructed flows at each site were selected to be as physically close as possible to the flow-reconstruction site and to have a drainage area similar to that of the site. However, given that there are differences between characteristics of the basin of the disaggregation streamgage and that of the flow-reconstruction site, it is likely that the predicted day of peak daily reconstructed flow may differ from the day of the actual peak.

\section{Daily and Monthly Reconstructed Flows Determined from Discrete Streamflow Measurements at Partial-Record Stations}

Daily and monthly reconstructed streamflows determined from discrete measurements of observed streamflows at partial-record stations are likely less accurate than corresponding values determined from monthly observed streamflows measured at a streamgage because the former are based on far less information. Examples of relations between discrete streamflow measurements and daily observed streamflows at Paulins Kill at Blairstown, N.J. (01443500), are shown in appendix 3 .

In addition, daily flows estimated from relations between discrete streamflow measurements and daily observed flows at index gages on days when streamflow is changing are likely to be less accurate than on those days when streamflow is constant. Measurements of discrete streamflow at most of the partial-record stations in this study (table 6) were made in order to define streamflow under base-flow conditions; these discrete measurements were likely made on days when streamflows were rather constant.

\section{Assessment of Reconstructed Streamflows}

The final reconstructed streamflow records were reviewed by comparing flow gained between sites going downstream during the study period 1922-2010. Most sites generally exhibit reasonable, consistent gains between sites throughout the study period. Notable exceptions include indications of flow lost instead of gained through Boonton Reservoir (fig. 14) and flow lost instead of gained on the Passaic River in the area between Pine Brook and Pompton Plains (Recon 49 and Recon 37) down to Little Falls (Recon53) (fig. 15). 
In comparing reconstructed flows upstream and downstream from Boonton Reservoir (Recon41 and Recon42), the data indicate relatively small fluctuations in gains and losses through the reservoir until the 1960s. From the late 1960s to the early 1980 s, there is a long period of steady streamflow losses through the reservoir, followed by a long period of steady gains from the 1980s through 2010 . There were substantial groundwater withdrawals in the subbasin that are not accounted for in these reconstructed streamflows. However, it is more likely that the gains and losses indicated by the reconstructed streamflows are an artifact of the inaccuracies of the reported storage in the Boonton Reservoir.

In the lower part of the Main Stem Passaic River subbasin, between Pine Brook (Recon 49), Pompton Plains (Recon37), and Little Falls (Recon53), it appears that the gains are not consistent, with variable periods of gaining and losing flow. There are several factors to consider when interpreting the results for this particular subbasin. The intervening flows between sites (Recon49, Recon37, and Recon53) were computed using the estimation of sectional flows, which were based on MOVE1 relations of intervening flow with flow at index gages. So, the first possibility is that the MOVE1 relations do not accurately reflect the hydrology of this section of the reach. However, this sectional flow estimation approach was chosen purposefully in an attempt to reflect the effects of the wetlands in this part of the subbasin, which are not present in the upper part of the Main Stem Passaic River subbasin. Using a simple drainage area adjustment would artificially "force" a steady, consistent gain and would not reflect the different basin characteristics in this part of the reach. Owing to the enhanced effects of evapotranspiration from increased vegetation in wetlands, it is common for streams to change from gaining to losing, depending on season and groundwater availability. So, it could be that the MOVE1 relation actually does a good job of representing this natural phenomenon over time. Another factor to consider is the amount of groundwater withdrawals that occur between sites, especially in the area upstream from Pine Brook (Recon49). Because groundwater flows were not accounted for in this reconstruction, they too may have an effect on the amount of water gain expected between sites.

\section{Data Release}

The data release associated with this report (Hickman, 2018) contains the following information: (1) some observed streamflow and diversion data that are not readily available to the public, (2) some estimated values of observed streamflows and monthly rates of transfer, (3) calculated monthly reconstructed streamflows, and (4) all monthly and daily reconstructed streamflows. Datasets are listed below.

1. Monthly hydrologic class determined for streams in northern New Jersey and southeastern New York, water years 1922-2010.
2. Unpublished and furnished daily observed streamflows at two streamgages in northern New Jersey, October 1965-September 2001.

3. Estimated daily observed streamflows at six partialrecord stations in northern New Jersey and southeastern New York, water years 1922-2010.

4. Monthly observed streamflows at selected streamgages estimated from records at other streamgages in northern New Jersey, water years 1922-2010.

5. End-of-month storage in Lake Hopatcong at Landing, N.J. (01455400), February 1887- September 2011.

6. Daily rates of transfer from diversions from Lake Hopatcong, Lake Wawayanda, and Pompton River during selected periods.

7. Monthly rates of transfer by two selected New Jersey American diversions, January 1965-December 1973.

8. Estimated monthly rates of transfer to Oradell Reservoir from three North Jersey District Water Supply Commission diversions, February 1985-September 2010.

9. Calculated monthly reconstructed streamflows at sites in northern New Jersey and southeastern New York, water years 1922-2010.

10. Equations used to estimate monthly reconstructed streamflows from calculated monthly reconstructed streamflows and monthly streamflows at index gages.

11. Monthly reconstructed streamflows at sites in northern New Jersey and southeastern New York, water years 1922-2010.

12. Daily reconstructed streamflows at flow-reconstruction sites in northern New Jersey and southeastern New York, water years 1922-2010.

\section{Summary}

A study was conducted by the U.S. Geological Survey, in cooperation with the New Jersey Department of Environmental Protection, to provide reconstructed streamflows for use in the RiverWare model. Methods and data used to estimate daily reconstructed streamflows in selected subbasins in northern New Jersey and southeastern New York used in the study are presented in this report. These subbasins contain one or more surface-water diversions (some not currently operating) by water purveyors or the New Jersey Department of Environmental Protection.

Reconstructed flows are those that would have occurred without the effects of changes in reservoir storage or 
surface-water diversions by water purveyors. Reconstructed flows were determined for 53 flow-reconstruction sites.

Reconstructed flows are used as input to the RIVERWARE streamflow accounting model developed by the New Jersey Department of Environmental Protection. Results of model can be used to determine the value of safe yield for water diversions by selected water purveyors in New Jersey.

Daily reconstructed flows at 46 sites were determined from reconstructed monthly flows adjusted for reservoir storage and surface-water diversions. Missing monthly reconstructed flows were estimated from relations between calculated values and monthly flows at index gages. Daily reconstructed flows were determined from the monthly reconstructed flows by using the records for selected streamgages. Daily reconstructed flows at six sites were estimated from relations between discrete streamflow measurements at partialrecord stations and daily streamflows at index gages. Streamflows at some partial-record stations represent water diverted from one stream channel to another.

The methods used in this study for flow reconstruction were not intended to provide a full accounting of water use and its implications on flow, but rather were intended to be used as one of many possible approaches to produce a dataset for further evaluation of water use. The daily reconstructed streamflows are available in a data release (Hickman, 2018). The data release includes selected data used for calculations so that comparisons of reconstructed flows can be made between sites.

\section{References Cited}

Center for Advanced Decision Support for Water and Environmental Systems, [n.d.], RiverWare, River Basin Modeling for Today and Tomorrow: Boulder, Colo., University of Colorado at Boulder, College of Engineering and Applied Science, Department of Civil, Environmental and Architectural Engineering, 8 p., accessed October 28, 2014, at http:// www.riverware.org/PDF/RiverWare/RiverWare-Brochure. pdf.

Dresnack, R., Golub, E., and Franklin, S., 1984, Safe yield study of the Passaic River Basin: Newark, N.J., New Jersey Institute of Technology, Department of Civil and Environmental Engineering, Contract WR 9-2-0 NJDEP, March 13, 1984, 15 p. plus figures and appendix, accessed May 29, 2007, at http://www.state.nj.us/dep/njgs/pricelst/gsreport/ gsr21.pdf.

Esralew. R.A., and Baker, R.J., 2008, Determination of baseline periods of record for selected streamflow-gaging stations in New Jersey for determining Ecologically Relevant Hydrologic Indices (ERHI): U.S. Geological Survey Scientific Investigations Report 2008-5077, 70 p., accessed March 23, 2013, at https://pubs.er.usgs.gov/publication/ $\operatorname{sir} 20085077$.
Hickman, R.E., 2018, Data and equations used to reconstruct historical daily streamflows in northern New Jersey and southeastern New York, water years 1922-2010: U.S. Geological Survey data release, https://doi.org/10.5066/ F7J965CZ.

Hirsch, R.M., 1982, A comparison of four streamflow record extension techniques: Water Resources Research, v. 18, no. 4, p. 1081-1088.

Langbein, W.B., and Iseri, K.T., 1960, General introduction and hydrologic definitions: U.S. Geological Survey WaterSupply Paper 1541-A, 29 p., accessed on July 7, 2014, at http://water.usgs.gov/wsc/glossary.html\#D.

Lawler, Matusky \& Skelly Engineers, 2004, Jersey City Municipal Utilities Authority, Reports on Reservoir Storage Volume and Safe Yield: Pearl River, N.Y., p. i to III-13 plus Appendix A.

New Jersey Department of Environmental Protection, 1983, New Jersey's Water Emergency, September 1980-April 1982, a report from the Water Emergency Task Force, May 1983: New Jersey Department of Environmental Protection, Division of Water Resources, 40 p., plus appendix.

New Jersey Department of Environmental Protection, 2011, Estimating the safe yield of surface water supply reservoir systems, Guidance Manual: Water Resource Management, Division of Water Supply and Geoscience, 42 p., accessed on March 9, 2017, at http://www.nj.gov/dep/watersupply/ pdf/safe-yield-manual.pdf.

New Jersey Geological and Water Survey, 2013, Reservoir storage and related diversions in the Passaic and Hackensack River Basins, 1898 to 2011: New Jersey Department of Environmental Protection, Digital Geodata Series DGS09-1, accessed April 4, 2013, at http://www.state.nj.us/dep/njgs/ geodata/dgs09-1.htm.

Storck, D.A., and Nawyn, J.P., 2001, Reconstruction of streamflow records in the Passaic and Hackensack River Basins, New Jersey and New York, water years 1993-96: U.S. Geological Survey Water-Resources Investigations Report 01-4078, 95 p. [Also available at http://pubs.er.usgs. gov/publication/wri014078.] 



\section{Appendix 1. Estimation of Monthly Observed Streamflows at Selected Streamgages}

Monthly observed streamflows for each of four selected streamgages were estimated from records of corresponding streamflow for one or more nearby streamgages. The selected streamgages are in the subbasins of the Saddle River, Pompton River, and Main Stem Passaic River.

\section{Saddle River Subbasin}

Monthly observed streamflows were estimated for the streamgages at Saddle River at Upper Saddle River, N.J. (01390450), and Saddle River below Hohokus Brook at Paramus, N.J. (01391102), (table 5, fig. 10, in the body of the report). Streamflows for the Saddle River at Upper Saddle River, N.J. (01390450), were estimated from the record of streamflows at the streamgage at Saddle River at Ridgewood, N.J. (01390500), using equations 1-1 and 1-2. For those months when streamflow at the gage at Ridgewood (01390500) was less than or equal to 50 cubic feet per second ( $\left.\mathrm{ft}^{3} / \mathrm{s}\right)$, flows at the gage at Upper Saddle River (01390450) were estimated from drainage-area adjustment of flows at Ridgewood by using equation 1-1. For months when streamflow at the gage at Ridgewood (01390500) was greater than $50 \mathrm{ft}^{3} / \mathrm{s}$, the monthly streamflows at the gage at Upper Saddle River (01390450) were estimated using equation 1-2. Equation 1-2 was developed from corresponding monthly observed streamflows at the two gages using the Maintenance of Variance Extension type 1 (Hirsch, 1982) described in appendix 5 .

$$
\begin{gathered}
m 01390450=m 01390500 \times\left(\frac{10.9}{21.6}\right) \\
m 01390450=(m 01390500 \times 0.723)-11.1
\end{gathered}
$$

where

$m 01390450$ is monthly observed streamflow at Saddle River at Upper Saddle River, N.J.

(01390450), in cubic feet per second; and

$m 01390500$ is monthly observed streamflow at Saddle River at Ridgewood, N.J.

(01390500), in cubic feet per second.

Monthly observed streamflows at the streamgage at Saddle River below Hohokus Brook at Paramus, N.J. (01391102), were estimated from the drainage-area adjustment of monthly streamflows at Saddle River at Lodi, N.J. (01391500), (table 5, fig. 10, in the body of the report). This relation is shown in equation 1-3.

$$
m 01391102=m 01391500 \times\left(\frac{43.3}{54.6}\right)
$$

where

$m 01391102$ is monthly observed streamflow at Saddle River below Hohokus Brook at Paramus, N.J. (01391102), in cubic feet per second; and

$m 01391500$ is monthly observed streamflow at Saddle River at Lodi, N.J. (01391500), in cubic feet per second.

\section{Pompton River Subbasin}

Monthly observed streamflows in the Pompton River at Pompton Plains, N.J. (01388500), were estimated by summing corresponding streamflows from three upstream streamgages and the estimated local contribution of streamflow downstream from these gages (table 5, fig. 13, 
in the body of the report). The three upstream streamgages are the Pequannock River at Macopin Intake Dam, N.J. (01382500); Wanaque River at Wanaque, N.J. (01387000); and Ramapo River at Pompton Lakes, N.J. (01388000). The local streamflow contribution, determined using equation 1-4, was based on the difference between observed streamflows on the Ramapo River near Mahwah, N.J. (01387500), and at Pompton Lakes, N.J. (01388000), after adjustment for the diversions at Pompton Lakes (Div15 and Div16 in table 4 in the body of the report). Equation 1-5 was used to calculate monthly observed streamflows in the Pompton River at Pompton Plains, N.J. (01388500).

$$
\begin{gathered}
\text { Local }=\frac{((m 01388000-m 01387500)+D i v 15+D i v 16)}{(160-120)} \times(355-(63.7+90.4+160)) \\
m 01388500=(m 01382500+m 01387000+m 01388000)+\text { Local }
\end{gathered}
$$

where

Local is monthly observed streamflow at the Pompton River at Pompton Plains, N.J. (01388500), originating downstream from the streamgages on the Pequannock River at Macopin Intake Dam, N.J. (01382500), Wanaque River at Wanaque, N.J. (01387000), and Ramapo River at Pompton Lakes, N.J. (01388000), in cubic feet per second;

Div15 is rate of transfer from Ramapo River at Pompton Lakes to Wanaque Reservoir, in cubic feet per second;

Div16 is rate of transfer from Ramapo River at Pompton Lakes to Oradell Reservoir, in cubic feet per second;

$m 01382500$ is monthly observed streamflow at Pequannock River at Macopin Intake Dam, N.J. (01382500), in cubic feet per second;

$m 01387000$ is monthly observed streamflow at Wanaque River at Wanaque, N.J.

(01387000), in cubic feet per second;

$m 01387500$ is monthly observed streamflow at Ramapo River near Mahwah, N.J.

(01387500), in cubic feet per second; and

$m 01388000$ is monthly observed streamflow at Ramapo River at Pompton Lakes, N.J.

(01388000), in cubic feet per second.

\section{Main Stem Passaic River Subbasin}

Monthly observed streamflows at the streamgage on the Passaic River near Chatham, N.J. (01379500), were estimated using the drainage-area adjustment of corresponding streamflows at the gage upstream at Passaic River near Millington, N.J. (01379000), (fig.15, table 5, in the body of the report). Equation is

$$
m 01379500=m 01379000 \times\left(\frac{100}{55.4}\right)
$$

where

$m 01379500$ is monthly observed streamflow at Passaic River near Chatham, N.J.

(01379500), in cubic feet per second; and

$m 01379000$ is monthly observed streamflow at Passaic River at Millington, N.J.

(01391000), in cubic feet per second.

\section{References Cited}

Hirsch, R.M., 1982, A comparison of four streamflow record extension techniques: Water Resources Research, v. 18, no. 4, p. 1081-1088. 


\section{Appendix 2. Calculation of Monthly Observed Streamflows in Beaver Brook at the Outlet of Splitrock Reservoir from Furnished Data}

Monthly observed streamflows at the streamgage on Beaver Brook at the outlet of Splitrock Reservoir, N.J. (01380000), in the Rockaway River subbasin were calculated using furnished records of stage readings at the outlet of the reservoir (table 5, fig.14, in the body of the report). Once-daily readings of stage were provided by Jersey City Bureau of Water during the period 1976-89. Measurements of streamflow were periodically made by the U.S. Geological Survey (USGS), and a stage-discharge rating curve was developed. Streamflows were determined using the once-daily, discrete stage readings provided by the Jersey City Bureau of Water and the rating curve developed by the USGS. The estimated observed flows are provided in the data release associated with this report (Hickman, 2018).

An examination of time-series plots of the daily streamflows in Beaver Brook at the outlet of Splitrock Reservoir, N.J. (01380000), revealed that the many of the daily discrete streamflows were unchanged from the streamflow on the previous day (fig. 2-1). These daily streamflows were divided into two groups — "unchanged" streamflows, which are the same as on the previous day, and "changed" streamflows, which are different from the value on the previous day.

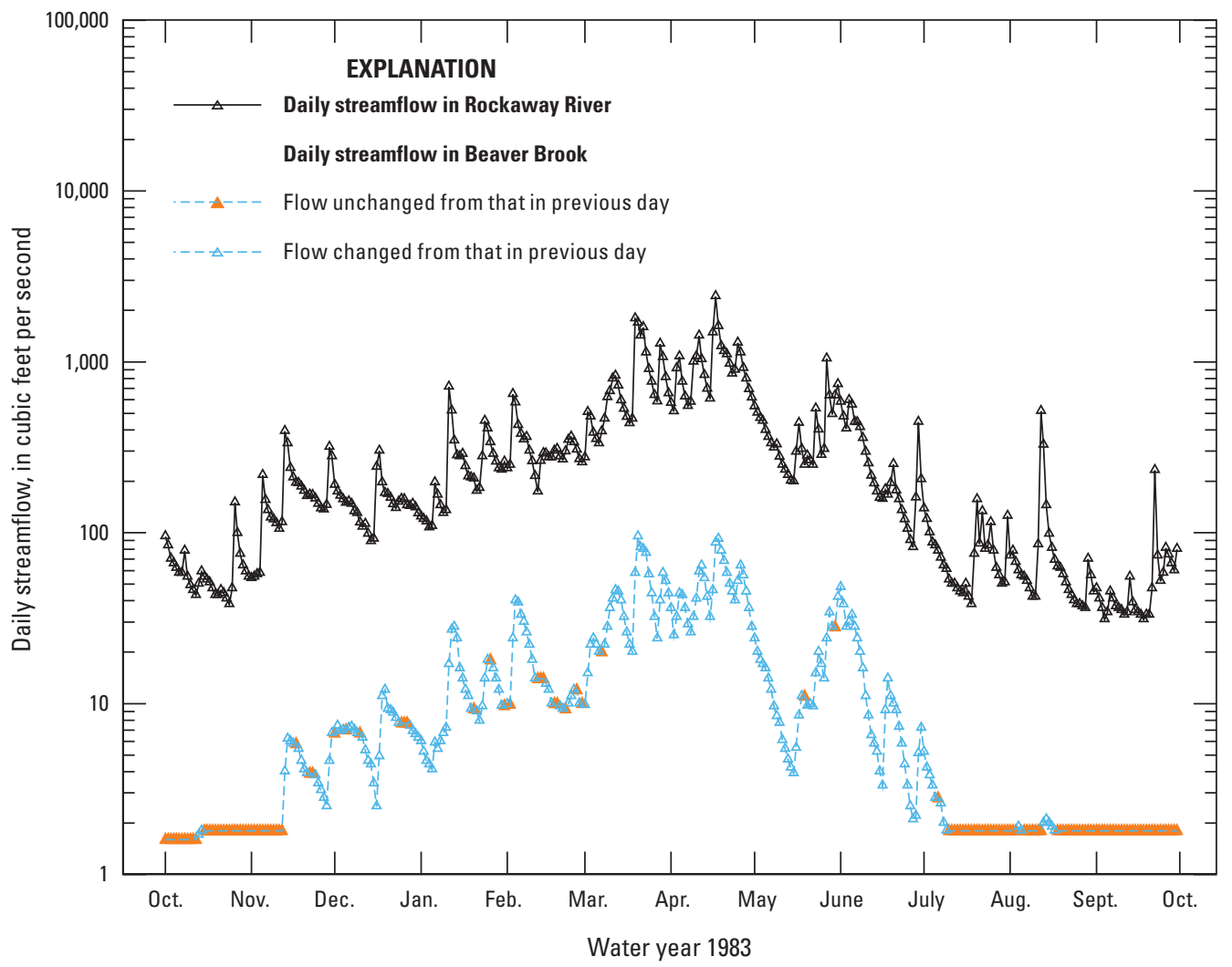

Figure 2-1. Time-series plots of daily streamflows in Beaver Brook at outlet of Splitrock Reservoir, N.J. (01380000), and in Rockaway River above Reservoir at Boonton, N.J. (01380500), water year 1983. 
The variation over time of the daily "changed" streamflows in Beaver Brook at the outlet of Splitrock Reservoir, N.J. (01380000), is similar to the variation shown by the daily streamflows measured at the downstream streamgage on the Rockaway River above Reservoir at Boonton, N.J. (01380500), during 1976-83 (fig. 2-2). The schematic diagram of the subbasin is shown in figure 14 in the body of the report. This similarity provides some support for the accuracy of the daily "changed" streamflows in Beaver Brook (01380000).

As a result of this comparison, monthly observed streamflows in Beaver Brook at the outlet of Splitrock Reservoir, N.J. (01380000), were calculated only for those months in which there were five or fewer "unchanged" daily streamflows. Monthly reconstructed flows for this site, Beaver Brook at the outlet of Splitrock Reservoir, N.J. (Recon39), were calculated by summing monthly observed streamflow and changes in monthly storage in Splitrock Reservoir (table 21 in the body of the report).

Monthly reconstructed flows in Beaver Brook at the outlet of Splitrock Reservoir, N.J. (Recon39), were calculated from monthly observed flows and changes in storage in Splitrock Reservoir. On the basis of flow per square mile, most monthly reconstructed flows at Beaver Brook at outlet of Splitrock Reservoir, N.J. (Recon39), are similar to the monthly observed streamflows in Rockaway River above Reservoir at Boonton, N.J. (01380500). The streamflows reflect the similar characteristics of the two basins and lend confidence to the use of the record even though the record was not published by the USGS.

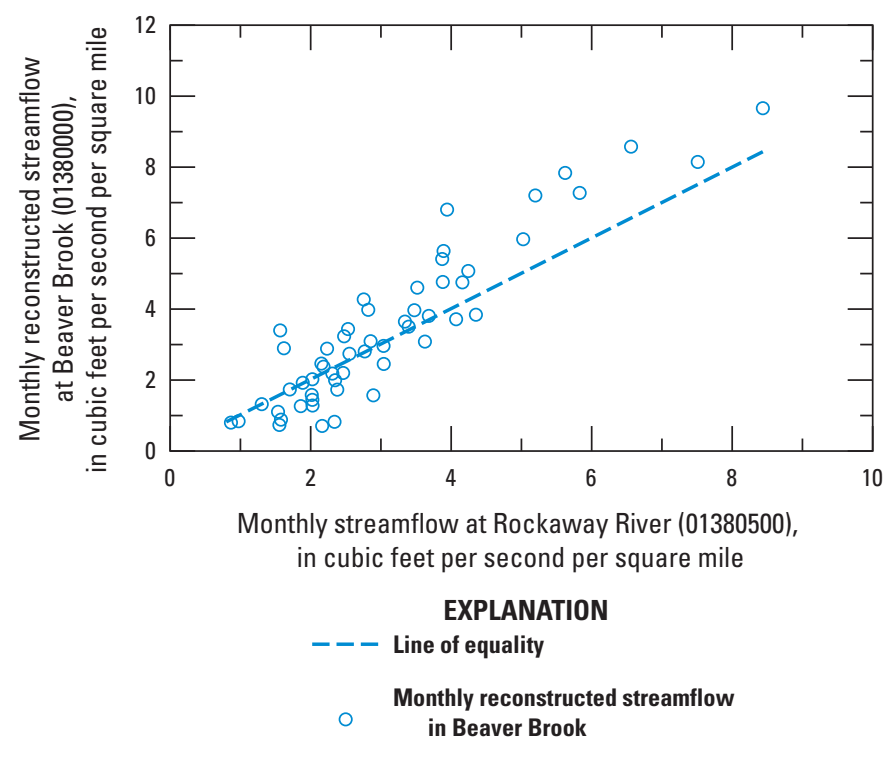

Figure 2-2. Selected monthly reconstructed streamflows per square mile in Beaver Brook at outlet of Splitrock Reservoir, N.J. (01380000), as a function of observed streamflow per square mile in Rockaway River above Reservoir at Boonton, N.J. (01380500), water years 1976-83.

\section{References Cited}

Hickman, R.E., 2018, Data and equations used to reconstruct historical daily streamflows in northern New Jersey and southeastern New York, water years 1922-2010: U.S. Geological Survey data release, https://doi.org/10.5066/F7J965CZ. 


\section{Appendix 3. Estimation of Observed Daily Streamflow at Six Partial-Record Stations}

Observed daily streamflows at six partial-record stations were estimated from relations between discrete streamflow measurements at each partial-record station and daily streamflows at each of the index gages. The relations took one of two forms. For most partial-record stations, a linear relation with the following form was developed:

$$
q_{\text {prstation }}=\left(q_{\text {index }} \times \text { slope }\right)+\text { intercept }
$$

where

$$
\begin{array}{cl}
q_{\text {prstation }} & \begin{array}{c}
\text { is discrete streamflow measurement at partial-record station, in cubic feet per } \\
\text { second; }
\end{array} \\
q_{\text {index }} & \begin{array}{c}
\text { is daily streamflow at index gage on day of discrete measurement, in cubic feet } \\
\text { per second; }
\end{array} \\
\text { slope } & \begin{array}{l}
\text { is slope of relation, unitless; and } \\
\text { intercept }
\end{array} \\
\text { is intercept of relation, in cubic feet per second. }
\end{array}
$$

As an example, measured discrete streamflows and predicted values from equation 3-1, as a function of daily observed streamflows at Paulins Kill at Blairstown, N.J. (01443500), are shown in figure 3-1 for two partial-record stations on Posts Brook in the Pompton River subbasin.

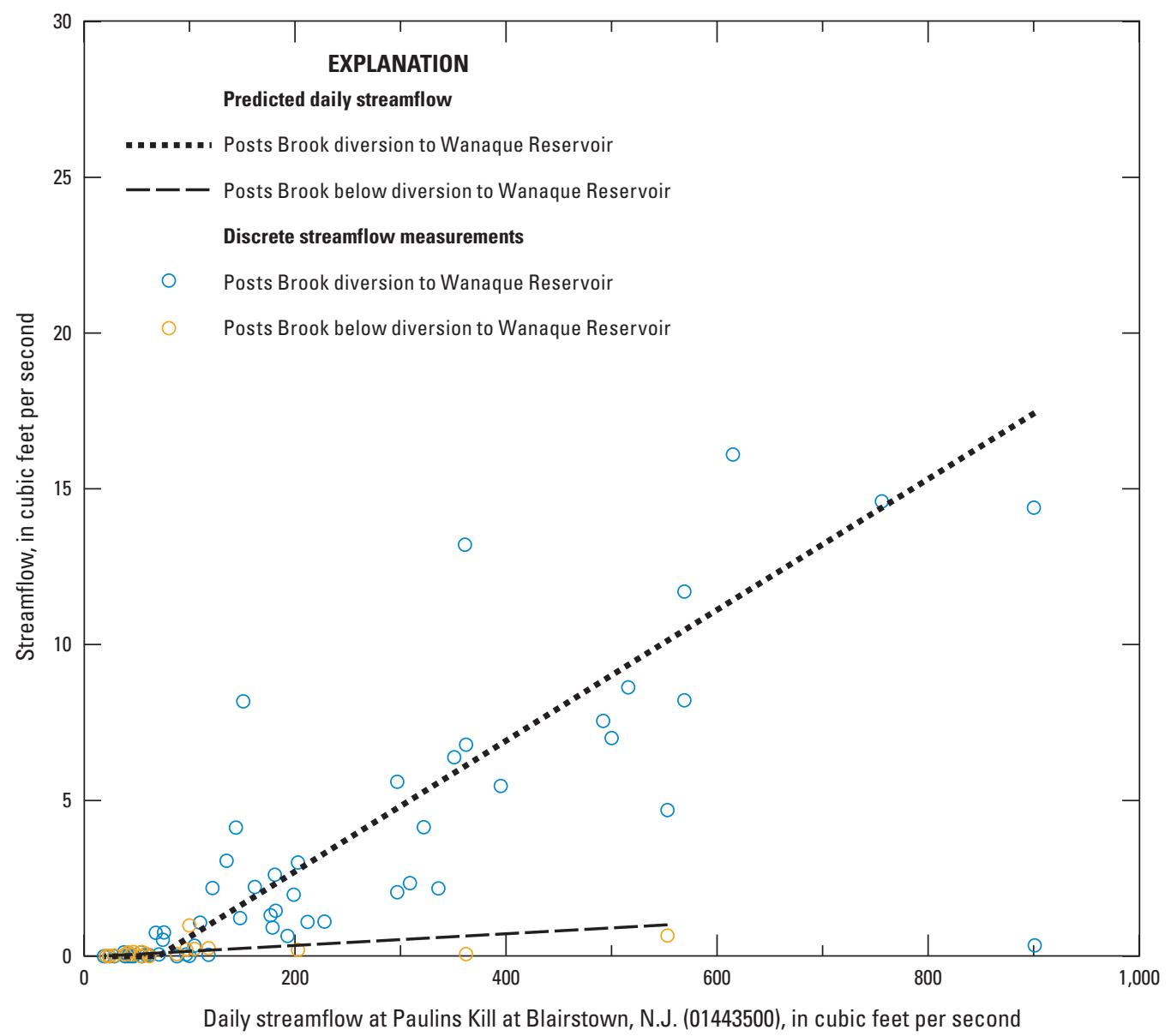

Figure 3-1. Discrete streamflow measurements at Posts Brook diversion to Wanaque Reservoir near Wanaque, N.J. (01387020), and Posts Brook below Wanaque diversion near Wanaque, N.J. (01387021), as a function of daily streamflow at Paulins Kill at Blairstown, N.J. (01443500), 1935-2014. 
Daily observed streamflows at the Auxiliary outlet of Upper Greenwood Lake at Moe, N.J. (01368720), were estimated with a different form of equation. A "semi-logarithmic" relation was used, as defined below.

$$
q_{\text {prstation }}=\left(\log \left(q_{\text {index }}\right) \times \text { slope }\right)+\text { intercept }
$$

where

$$
\begin{aligned}
& q_{\text {prstation }} \begin{array}{l}
\text { is discrete streamflow measurement at partial-record station, in cubic feet per } \\
\text { second; }
\end{array} \\
& \log \begin{array}{l}
\text { is base-10 logarithm; } \\
\text { is daily streamflow at index gage on day of discrete measurement, in cubic feet } \\
q_{\text {index }} \\
\text { per second; }
\end{array} \\
& \text { slope } \begin{array}{l}
\text { is slope of relation, unitless; and } \\
\text { intercept }
\end{array} \\
& \text { is intercept of relation, in cubic feet per second. }
\end{aligned}
$$

A plot of the discrete streamflow measurements at the Auxiliary outlet of Upper Greenwood Lake at Moe, N.J. (01368720), as a function of daily observed streamflows in Paulins Kill at Blairstown, N.J. (01443500), is given in figure 3-2.

Relations between discrete measurements and daily flows at each index gage were determined by use of the Maintenance of Variance Extension type 1 (MOVE1) (Hirsch, 1982) as described in appendix 5. Equation slope and intercepts are given in table 3-1.

Daily observed flows at each partial-record station were estimated using the developed MOVE1 equations and the daily flows in the Paulins Kill at Blairstown, N.J (01443500), except for days of missing daily flows in water year 1977 (table 3-1). For daily flows missing in water year 1977, daily observed flows estimated with equations and daily flows at the Pequest River at Pequest, N.J. (01445500), were used. Estimated daily values less than zero were set to zero.

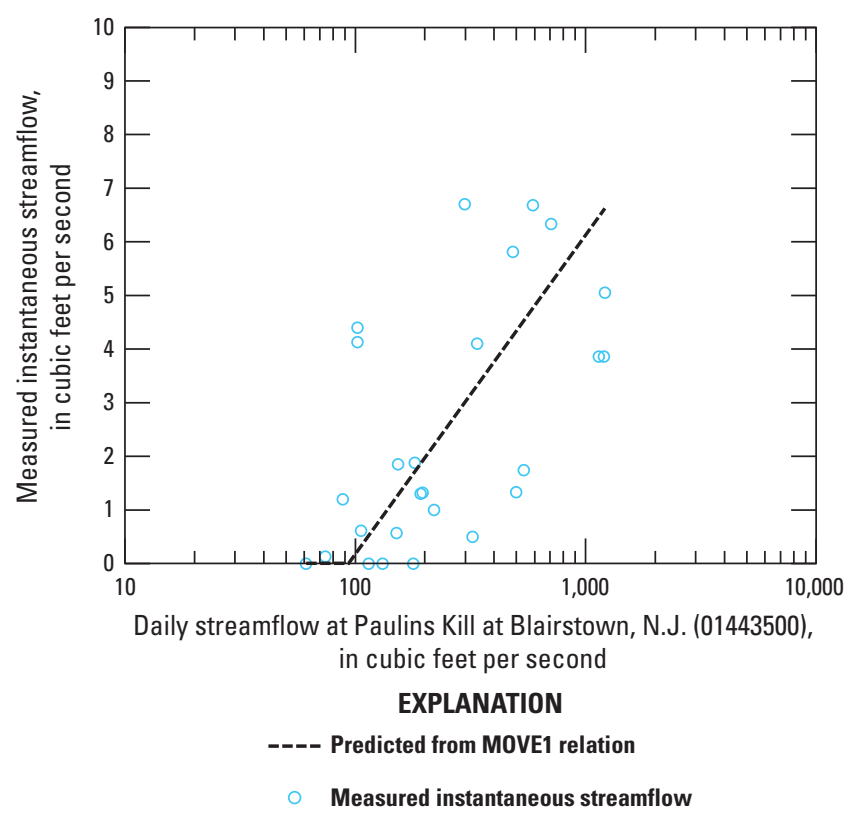

Figure 3-2. Discrete streamflow measurements at Auxiliary outlet of Upper Greenwood Lake at Moe, N.J. (01368720), as a function of daily streamflow in Paulins Kill at Blairstown, N.J. (01443500), 1975-80. 
Table 3-1. Relations between discrete streamflow measurements at selected partial-record stations and daily streamflows at each of the index streamgages, northern New Jersey and southeastern New York.

[Straight and semi-logarithmic are defined in the text.; N.J., New Jersey; N.Y., New York; USGS, U.S. Geological Survey]

\begin{tabular}{|c|c|c|c|c|c|c|c|c|}
\hline \multirow{3}{*}{$\begin{array}{l}\text { Partial-record station } \\
\text { (USGS station number) }\end{array}$} & \multirow{3}{*}{$\begin{array}{l}\text { Type of } \\
\text { relation } \\
\text { with index } \\
\text { streamgage }\end{array}$} & \multirow{2}{*}{\multicolumn{2}{|c|}{$\begin{array}{c}\text { Period of } \\
\text { discrete } \\
\text { streamflow } \\
\text { measurements, } \\
\text { in water years }\end{array}$}} & \multirow{3}{*}{$\begin{array}{l}\text { Number of } \\
\text { discrete } \\
\text { streamflow } \\
\text { measurements }\end{array}$} & \multicolumn{4}{|c|}{$\begin{array}{l}\text { Slope and intercept for equation } \\
\text { between discrete streamflow } \\
\text { measurements and daily } \\
\text { streamflows at each index gage }\end{array}$} \\
\hline & & & & & \multicolumn{2}{|c|}{$\begin{array}{c}\text { Paulins Kill at } \\
\text { Blairstown, N.J. } \\
\text { (01443500) }\end{array}$} & \multicolumn{2}{|c|}{$\begin{array}{l}\text { Pequest River } \\
\text { at Pequest, N.J. } \\
\text { (01445500) }\end{array}$} \\
\hline & & First & Last & & Slope & Intercept & Slope & Intercept \\
\hline \multicolumn{9}{|c|}{ Hirshfeld Brook } \\
\hline $\begin{array}{l}\text { Hirshfeld Brook at } \\
\text { New Milford, N.J. } \\
(01378520)\end{array}$ & Straight & 1965 & 2010 & 33 & 0.012 & 1.155 & 0.017 & 0.939 \\
\hline \multicolumn{9}{|c|}{ Double Kill } \\
\hline $\begin{array}{l}\text { Double Kill at } \\
\text { Wawayanda, N.J. } \\
(01368820)\end{array}$ & Straight & 1998 & 2012 & 58 & 0.064 & -2.378 & 0.109 & -6.211 \\
\hline \multicolumn{9}{|c|}{ Long House Creek } \\
\hline $\begin{array}{l}\text { Auxiliary outlet of } \\
\text { Upper Greenwood } \\
\text { Lake at Moe, N.J. } \\
(01368720) \\
\end{array}$ & $\begin{array}{l}\text { Semi- } \\
\text { logarithmic }\end{array}$ & 1975 & 1980 & 29 & 5.967 & -11.770 & 6.038 & -11.456 \\
\hline $\begin{array}{l}\text { Long House Creek } \\
\text { below Cascade } \\
\text { Lake, N.Y. } \\
(01368722)\end{array}$ & Straight & 1973 & 1976 & 18 & 0.086 & -6.292 & 0.104 & -8.033 \\
\hline \multicolumn{9}{|c|}{ Pompton River } \\
\hline $\begin{array}{l}\text { Posts Brook diversion } \\
\text { to Wanaque } \\
\text { Reservoir near } \\
\text { Wanaque, N.J. } \\
(01387020)\end{array}$ & Straight & 1935 & 2014 & 56 & 0.021 & -1.488 & 0.027 & -1.782 \\
\hline $\begin{array}{l}\text { Posts Brook below } \\
\text { Wanaque diversion } \\
\text { near Wanaque, N.J. } \\
(01387021)\end{array}$ & Straight & 2005 & 2014 & 19 & 0.002 & -0.032 & 0.002 & -0.029 \\
\hline
\end{tabular}

\section{References Cited}

Hirsch, R.M., 1982, A comparison of four streamflow record extension techniques: Water Resources Research, v. 18, no. 4, p. 1081-1088. 


\section{Appendix 4. Estimation of Monthly Transfer Rates of the Three Pipe Diversions Used by the North Jersey District Water Supply Commission to Transfer Water to Oradell Reservoir}

Since February 1985, the North Jersey District Water Supply Commission (NJDWSC) has transferred water to Oradell Reservoir in the Hackensack River subbasin (fig. 10 in the body of the report) by use of one or more of three pipe diversions (table 4 in the body of the report). The Wanaque Reservoir diversion to Oradell Reservoir, N.J. (Div13), transferred water from the Wanaque River subbasin (fig. 12 in the body of the report). The Ramapo River diversion to Oradell Reservoir at Pompton Lakes, N.J. (Div16), transferred water from the Pompton River subbasin (fig. 13 in the body of the report). The Pompton River diversion to Oradell Reservoir at Two Bridges, N.J. (Div24), transferred water from the Main Stem Passaic River subbasin (fig. 15 in the body of the report). The total amount of water transferred to Oradell Reservoir from all these diversions was available (New Jersey Geological and Water Survey, 2013), but the rates for each of the individual diversions were not.

The rates of monthly transfers to Oradell Reservoir from each of the three diversions (Div13, Div16, and Div24) were estimated from the total water sent to Oradell Reservoir (New Jersey Geological and Water Survey, 2013), based on two types of information.

The first type of information consists of dates of initial use of each diversion to transfer water to Oradell Reservoir. According to the Bauersfeld and others (1990), the water transferred to Oradell Reservoir by the North Jersey District Water Supply Commission from 1985 through water year 1988 was entirely from the Ramapo River (Div16). Also, according to NJDWSC (Dag Madara, NJDWSC, written commun. 2015), the earliest diversion from the Wanaque Reservoir to Oradell (Div13) occurred in July 1987—a diversion of 20.7 million gallons per day on one dayduring an assumed test of the system; this diversion was not used again until July 1988.

The second type of information came from a suggestion by Dag Madara (NJDWSC, written commun., 2015) to estimate the diversions in use in each month from a comparison of (1) the amount of water transferred to Oradell Reservoir by the NJDWSC (sum of Div13, Div16, and Div24) and (2) the amount of water transferred to the Wanaque Reservoir from the Ramapo and Pompton Rivers (sum of Div15 and Div23).

For those months when the amount of water transferred to Oradell Reservoir from all sources (sum of Div13, Div16, and Div24) was less than or equal to the amount of water transferred from the Ramapo and Pompton Rivers to the Wanaque Reservoir (sum of Div15 and Div23), the water transferred to the Oradell was assumed to have come entirely from the two rivers and none from the Wanaque Reservoir. For these months, the water transferred from each river to the Oradell Reservoir (Div16 and Div24) was calculated by prorating the water transferred to Oradell on the basis of the amounts of water transferred from each river to the Wanaque Reservoir (Div15 and Div23). The amount of water transferred to Wanaque Reservoir from each river was then reduced by the amount estimated to have been transferred from that river to the Oradell Reservoir. The amount of water assumed to have been transferred from the Wanaque Reservoir to the Oradell Reservoir (Div13) was set to zero.

If the amount of water transferred by the NJDWSC to Oradell Reservoir (sum of Div13, Div16, and Div24) was greater than the amount of water reported to have been transferred to the Wanaque Reservoir from the Ramapo and Pompton Rivers (sum of Div15 and Div23), then all water was assumed to have come from the Wanaque Reservoir. Diversions to Oradell Reservoir from the Ramapo and Pompton Rivers (Div15 and Div24) were set to zero.

\section{References Cited}

Bauersfeld, W.R., Moshinsky, E.W., Pustay, E.A., and Jones, W.D., 1990, Water Resources Data - New Jersey, Water Year 1989, Volume 1, Atlantic Slope Basins, Hudson River to Cape May: U.S. Geological Survey Water-Data Report NJ-89-1, 339 p., plus index. 


\section{Appendix 5. Maintenance of Variance Extension Type 1}

The Maintenance of Variance Extension type 1 (MOVE1) was proposed as a method to estimate missing values of streamflow at one streamgage from the relation between streamflows at that streamgage (dependent) and corresponding streamflows at another streamgage (independent) over the same period by Hirsch (1982). The equation given below has been modified to show separate terms for slope and intercept. The equation estimates streamflows at the dependent streamgage using streamflows at the independent streamgage. The equation is determined from a series of concurrent streamflow measurements at the independent index gage and at the dependent streamgage.

$$
\operatorname{estQdep}(i)=\operatorname{Qind}(i) \times\left[\frac{S(\text { Qdep })}{S(\text { Qind })}\right]_{\text {slope }}+\left[m(\text { Qdep })-\left(\frac{S(\text { Qdep })}{S(\text { Qind })}\right) \times m(\text { Qind })\right]_{\text {intercept }}
$$

where

estQdep (i) is estimated streamflow at dependent streamgage during period, $i$;

Qind (i) is streamflow at dependent streamgage during period, $i$;

$S$ (Qdep) is standard deviation of streamflows at dependent streamgage;

$S$ (Qind) is standard deviation of streamflows at independent streamgage;

$m($ Qdep $) \quad$ is mean of streamflow at dependent streamgage; and

$m$ (Qind) is mean of streamflow at independent streamgage.

\section{References Cited}

Hirsch, R.M., 1982, A comparison of four streamflow record extension techniques: Water Resources Research, v. 18, no. 4, p. 1081-1088. 

For additional information, contact::

Director, New Jersey Water Science Center U.S. Geological Survey

3450 Princeton Pike, Suite 110

Lawrenceville, NJ 08648

or visit our website at: https://nj.usgs.gov/

Publishing support provided by the West Trenton Publishing Service Center 
